ORNL/TM-1999/247

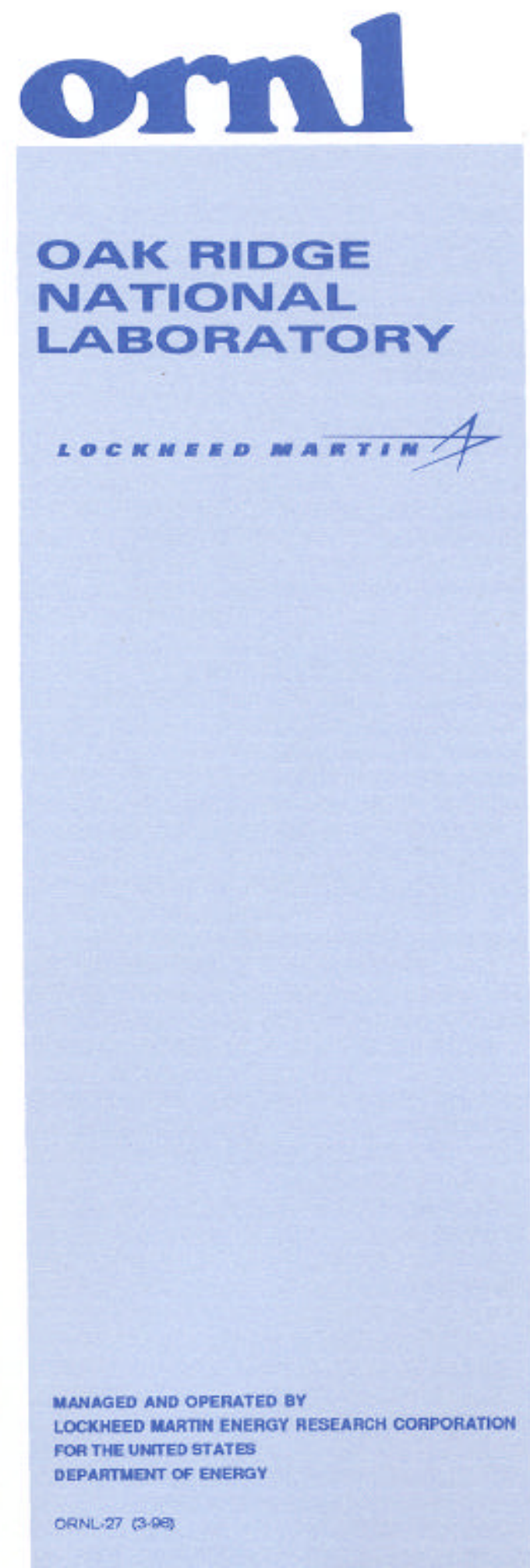

\title{
SCALE-4 Analysis of LaSalle Unit 1 BWR Commercial Reactor Critical Configurations
}

I. C. Gauld

MANAGED AND OPERATED BY

LOCKHEED MARTIN ENERGY RESEARCH CORPORATION FOR THE UNITED STATES

ORNL-27 (3.2) 
This report has been reproduced directly from the best available copy.

Available to DOE and DOE contractors form the Office of Scientific and Technical Information, P.O. Box 62, Oak Ridge, TN 37831; prices available from (615) 576-8401.

Available to the public from the National Technical Information Service, U.S. Department of Commerce, 5285 Port Royal Rd., Springfield, VA 22161.

This report was prepared as an account of work sponsored by an agency of the United States Government. Neither the United States nor any agency thereof, nor any of their employees, makes any warranty, express or implied, or assumes any legal liability or responsibility for the accuracy, completeness, or usefulness of any information, apparatus, product, or process disclosed, or represents that its use would not infringe privately owned rights. Reference herein to any specific commercial product, process, or service by trade name, trademark, manufacturer, or otherwise, does not necessarily constitute or imply its endorsement, recommendation, or favoring by the United States Government or any agency thereof. The views and opinions of authors expressed herein do not necessarily state or reflect those of the United States Government or any agency thereof. 


\title{
SCALE-4 Analysis of LaSalle Unit 1 BWR Commercial Reactor Critical Configurations
}

\author{
I. C. Gauld
}

Date Published: March 2000

\author{
Prepared by the \\ OAK RIDGE NATIONAL LABORATORY \\ Oak Ridge, Tennessee 37831 \\ managed by \\ LOCKHEED MARTIN ENERGY RESEARCH CORP. \\ for the \\ U.S. DEPARTMENT OF ENERGY \\ under contract DE-AC05-96OR22464
}





\section{CONTENTS}

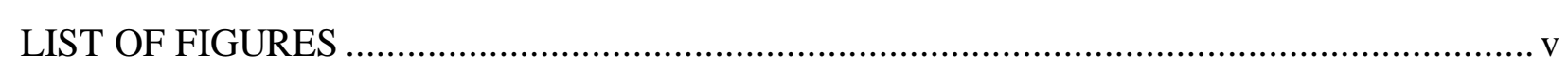

LIST OF TABLES.. .............................................................................................. vii

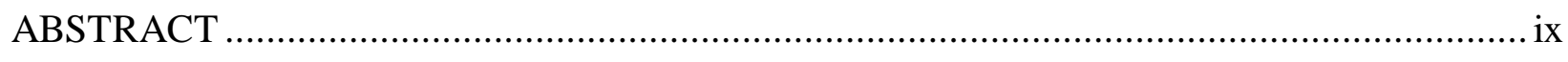

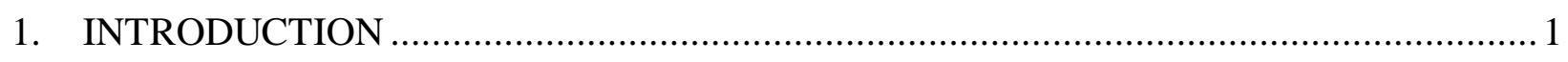

2. $\quad$ REACTOR DESCRIPTION ... …........................................................................... 3

2.1. $\quad$ FUEL ASSEMBLY DESIGN DESCRIPTION .... .............................................. 3

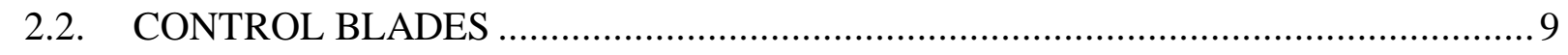

3. LASALLE UNIT 1 CRITICAL STATEPOINT DATA................................................. 13

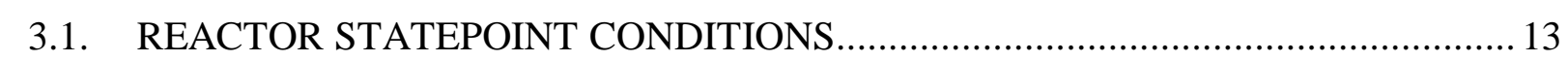

3.2. $\quad$ FUEL ASSEMBLY CONFIGURATION. . ..................................................... 13

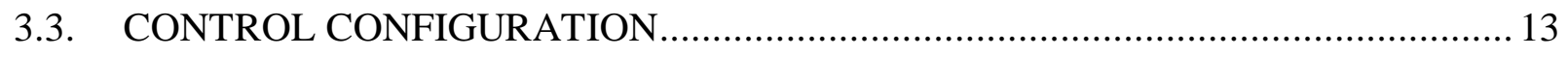

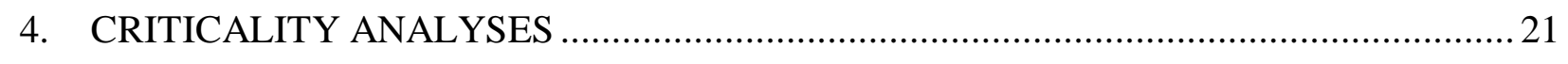

4.1. OVERVIEW OF THE METHODOLOGY.......................................................... 21

4.2. CODE VERSIONS AND COMPUTER PLATFORM.......................................... 21

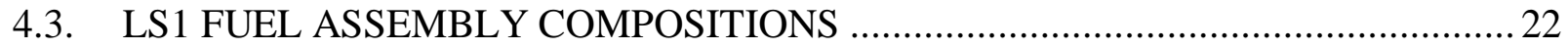

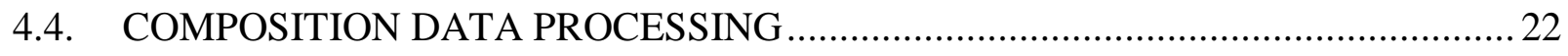

$4.5 . \quad$ CRUSS-SECTIUN PRUCESSING .................................................................. 23

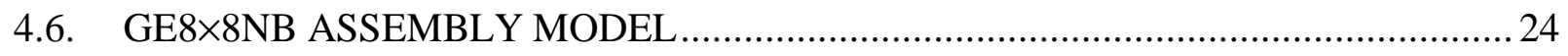

4.7. LASALLE UNIT 1 REACTOR MODEL ............................................................. 26

4.8. SUMMARY OF KEY ANALYSIS APPROXIMATIONS .................................... 30

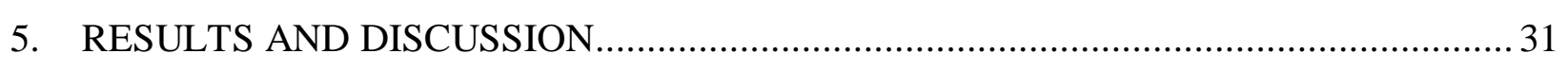

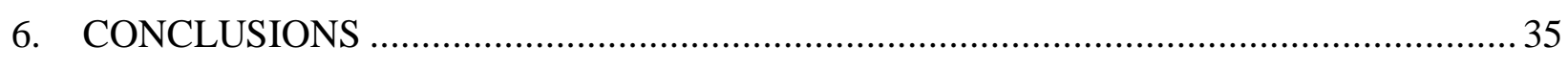

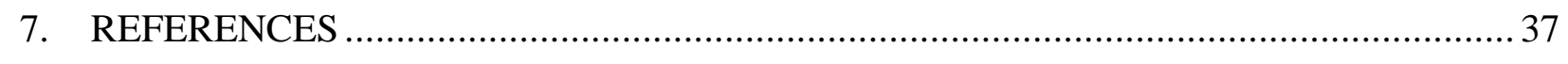

APPENDIX A: CSASI INPUT LISTING FOR ASSEMBLY C14, ZONE 4, SP11 ............... 41

APPENDIX B: GECKO FORTRAN UTILITY CODE LISTING ...................................... 47

APPENDIX C: LS1K FORTRAN UTILITY CODE LISTING AND ASSEMBLY MAP ........ 55

APPENDIX D: ABRIDGED KENO V.A INPUT LISTING FOR LS1 STATEPOINT CONFIGURATIONS 



\section{LIST OF FIGURES}

Figure

$\underline{\text { Page }}$

\begin{tabular}{|ll}
\hline 1. & GE8 $\times 8 N B$ assemblies and control-cell arrangement $\ldots$ \\
\hline \hline 2. & GE8X8NB assembly axial section $\ldots \ldots \ldots \ldots \ldots$
\end{tabular}





\section{LIST OF TABLES}

Table

1. LaSalle Unit 1 fuel assembly and reactor data

2. Fuel assembly descriptions for 10 axial nodes................................................... 5

3. Fuel assembly cross-section properties …................................................. 6

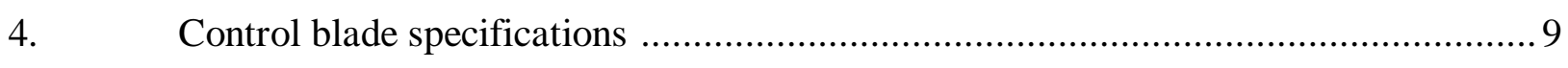

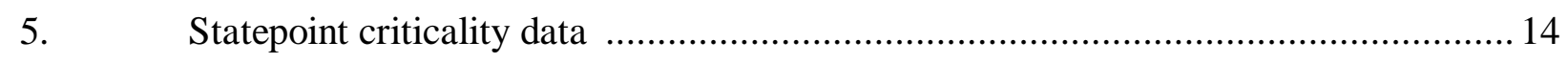

6. Calculated $k_{\text {eff }}$ for LS1 statepoints ....................................................... 32 



\begin{abstract}
Five commercial reactor criticals (CRCs) for the LaSalle Unit 1 boiling-water reactor have been analyzed using KENO V.a, the Monte Carlo criticality code of the SCALE 4 code system. The irradiated fuel assembly isotopics for the criticality analyses were provided by the Waste Package Design team at the Yucca Mountain Project in the United States, who performed the depletion calculations using the SAS2H sequence of SCALE 4. The reactor critical measurements involved two beginning-of-cycle and three middle-of-cycle configurations. The CRCs involved relatively low-cycle burnups, and therefore contained a relatively high gadolinium poison content in the reactor assemblies. This report summarizes the data and methods used in analyzing the critical configurations and assesses the sensitivity of the results to some of the modeling approximations used to represent the gadolinium poison distribution within the assemblies. The KENO V.a calculations, performed using the SCALE 44GROUPNDF5 ENDF/B-V cross-section library, yield predicted $k_{\text {eff }}$ values within about $1 \%$ $\Delta k / k$ relative to reactor measurements for the five CRCs using general 8-pin and 9-pin heterogeneous gadolinium poison pin assembly models.
\end{abstract}





\section{INTRODUCTION}

As part of an ongoing program to develop and validate the criticality safety analysis methodology for the disposal of commercial spent nuclear fuel by the U.S. Department of Energy Office of Civilian Radioactive Waste Management (OCRWM), commercial reactor criticality (CRC) data for the LaSalle Unit 1 (LS1) boiling-water reactor (BWR) have been compiled to provide a database for code validation studies involving BWR-type fuel assemblies ${ }^{1}$

The critical reactor configurations for LS1 have been analyzed using the KENO V.a Monte Carlo criticality analysis code ${ }^{2}$ developed as part of the SCALE system ${ }^{3}$ The reactor critical measurements were all performed following reactor shutdown, either at the beginning-of-cycle (BOC) or after a reactor trip during a cycle. The reactor conditions and state at the time the reactor first attains criticality is referred to as a statepoint (SP). These states involve zero-power conditions and are attained after sufficient cooling time to allow the fission product xenon inventory to decay. A total of five statepoints have been analyzed: two involving BOC conditions, and the remaining three involving a cycle burnup of less than $8000 \mathrm{MWd} / \mathrm{MTU}$.

The GE8 $\times 8$ NB-type fuel assemblies in the LS1 reactor incorporate an integral burnable gadolinia $\left(\mathrm{Gd}_{2} \mathrm{O}_{3}\right)$ poison in some of the fuel pins. The statepoint criticals were performed at BOC, or relatively low-cycle burnups, and consequently these measurements involved a significant number of reactor fuel assemblies with high concentrations of the burnable poison still present. The presence of gadolinium poison in the assemblies introduces a significant level of heterogeneity in the calculations. In addition, the critical statepoints were achieved with approximately $70 \%$ insertion of the boron carbide $\left(\mathrm{B}_{4} \mathrm{C}\right)$ control blades in the core, making these highly heterogeneous critical configurations.

The primary objective of this report is to provide an independent criticality assessment of the LS1 statepoint criticals to verify previous analyses performed by the Yucca Mountain Project Waste Package Design team under OCRWM. The irradiated fuel assembly isotopics for the criticality analyses were obtained directly from the Waste Package Design team and served as a common reference point for the analyses. This report summarizes the calculated results obtained using KENO V.a, discusses the methods and approximations used in the criticality assessment model, and provides a brief discussion of the sensitivity of the criticality results to the methods and approximations used in representing the integrated burnable gadolinia rods in the assemblies. 



\section{REACTOR DESCRIPTION}

LaSalle Unit 1 is a General Electric BWR with a rated power of $3323 \mathrm{MWt}$. Control of reactivity is accomplished in part by a combination of control blade movements and integral burnable gadolinia $\left(\mathrm{Gd}_{2} \mathrm{O}_{3}\right)$ absorbers. The core has a total of 185 control blades. The reactor vessel internal shroud is a stainless steel cylinder, which surrounds the reactor core and serves as a barrier to separate the upward flow of the coolant through the reactor core from the downward flow of the coolant outside the core.

This section describes the general LS1 reactor design information relevant to the reactor configuration during the SP measurements and includes the fuel assembly design, control blade design, and fuel assembly compositions.

\subsection{FUEL ASSEMBLY DESIGN DESCRIPTION}

The LS1 reactor core contains 764 fuel assemblies. All fuel assemblies used in the LS1 reactor critical SP measurements were of the GE8 $\times 8 \mathrm{NB}$ (GE9)-type, designed and manufactured by General Electric. The assembly has ferrule-type spacer grids, a large-diameter central water rod that spans four fuel pin positions, axially zoned enrichment, and integral burnable gadolinia $\left(\mathrm{Gd}_{2} \mathrm{O}_{3}\right)$ absorbers. Additionally, this fuel assembly has a 12 -in. natural uranium blanket at the top of the assembly. The fuel assembly and fuel channel specifications are listed in Table 1. Figure 1 illustrates the GE8 $\times 8 \mathrm{NB}$ fuel-assembly and control-blade arrangement. Figure 2 illustrates some of the axial detail of the assembly.

The burnable gadolinia $\left(\mathrm{Gd}_{2} \mathrm{O}_{3}\right)$ poison in the $\mathrm{GE} 8 \times 8 \mathrm{NB}$ fuel assemblies is integrated with the enriched uranium in a limited number (between 7 and 12) of assembly pins to reduce the reactivity of the fuel during the initial phase of reactor operation. In general, the effect of the gadolinium poison on $k_{\text {eff }}$ is most significant during the initial $10 \mathrm{GWd} / \mathrm{MTU}$ of operation, after which the gadolinium absorber has been typically depleted to low concentrations.

The axially zoned enrichment of the fuel assemblies is approximated using 10 axial zones to represent the axial depletion effects. The height of each axial zone and fuel zone identifiers for each assembly type residing in the reactor during the critical measurements (Cycles 7 and 8) are listed in Table 2. The table provides composition identifiers or "cross sections" for each axial zone of the nine assembly types that resided in the reactor core during the five-statepoint measurements. These identifiers are used to cross reference the actual fuel zone compositions and configurations which are listed in Table 3. The assembly types, characterized by their unique axial enrichment and gadolinium poison pin arrangement, are referenced by number $(1,2$, $4,5$, and $8-12$ ) and also by alphanumeric designations (A-H, and $\mathrm{J})$. 
Table 1. LaSalle Unit 1 fuel assembly and reactor data

\begin{tabular}{ll}
\hline \multicolumn{1}{c}{ Description } & \multicolumn{1}{c}{ Data } \\
\hline Fuel assembly array size and type & GE8×8NB (GE9B) \\
Number of fuel pins / assembly & 60 (enriched axial zones) \\
& $48-60$ (natural uranium axial end zones) \\
Number of water rods / assembly & 1 \\
Number of assemblies in core & 764 \\
Number of control blades in core & 185 \\
System pressure & $1020 \mathrm{psia}(7.03266 \mathrm{MPa})$ \\
Active fuel height (H) & $381.00 \mathrm{~cm}$ \\
Pin pitch & $1.6256 \mathrm{~cm}$ \\
Assembly pitch (P) & $15.24 \mathrm{~cm}$ \\
Fuel pin cladding outer diameter (OD) & $1.2268 \mathrm{~cm}$ \\
Fuel pin cladding inner diameter (ID) & $1.06426 \mathrm{~cm}$ \\
Fuel pin clad thickness & $0.08128 \mathrm{~cm}$ \\
Fuel pin cladding material & Zircaloy \\
Fuel pellet diameter & $1.04394 \mathrm{~cm}$ \\
Fuel material & UO 2 \\
Water rod outside diameter & $3.4036 \mathrm{~cm}$ \\
Water rod inside diameter & $3.2004 \mathrm{~cm}$ \\
Water rod material & Zircaloy \\
Channel - inner width & $13.4061 \mathrm{~cm}$ \\
- thickness Cycles 4-7 & $0.254 \mathrm{~cm}$ \\
- thickness Cycle 8 & $0.203 \mathrm{~cm}$ \\
Channel material & Zircaloy \\
\hline
\end{tabular}


Table 2. Fuel assembly descriptions for $\mathbf{1 0}$ axial zones

\begin{tabular}{|c|c|c|c|c|c|c|c|c|c|c|}
\hline \multirow[b]{2}{*}{$\begin{array}{l}\text { Axial } \\
\text { zone }\end{array}$} & \multirow[b]{2}{*}{$\begin{array}{c}\text { Length } \\
(\mathrm{cm})\end{array}$} & \multicolumn{9}{|c|}{ Cross-Section Reference Number by Zone } \\
\hline & & $\begin{array}{l}\text { Type } \\
8 \text { (B) } \\
\text { fuel }\end{array}$ & $\begin{array}{l}\text { Type } \\
9(\mathrm{~A}) \\
\text { fuel }\end{array}$ & $\begin{array}{c}\text { Type } \\
10 \\
(\mathrm{C}) \\
\text { fuel } \\
\end{array}$ & $\begin{array}{c}\text { Type } \\
11 \\
\text { (D) } \\
\text { fuel }\end{array}$ & $\begin{array}{c}\text { Type } \\
12 \\
\text { (E) } \\
\text { fuel }\end{array}$ & $\begin{array}{l}\text { Type } \\
1(\mathrm{G}) \\
\text { fuel }\end{array}$ & $\begin{array}{l}\text { Type } \\
2(\mathrm{~F}) \\
\text { fuel }\end{array}$ & $\begin{array}{l}\text { Type } \\
4(\mathrm{~J}) \\
\text { fuel }\end{array}$ & $\begin{array}{l}\text { Type } \\
5(\mathrm{H}) \\
\text { fuel }\end{array}$ \\
\hline 10 (Тор) & 15.24 & 106 & 100 & 112 & 127 & 122 & 117 & 145 & 145 & 139 \\
\hline 9 & 15.24 & 107 & 101 & 113 & 128 & 123 & 150 & 134 & 146 & 140 \\
\hline 8 & 45.72 & 108 & 102 & 114 & 129 & 124 & 118 & 135 & 147 & 141 \\
\hline 7 & 45.72 & 109 & 103 & 115 & 130 & 125 & 119 & 136 & 148 & 142 \\
\hline 6 & 45.72 & 110 & 104 & 115 & 131 & 126 & 120 & 137 & 149 & 143 \\
\hline 5 & 45.72 & 110 & 104 & 115 & 131 & 126 & 120 & 137 & 149 & 143 \\
\hline 4 & 45.72 & 110 & 104 & 115 & 131 & 126 & 120 & 137 & 149 & 143 \\
\hline 3 & 60.96 & 111 & 105 & 116 & 132 & 124 & 121 & 138 & 147 & 144 \\
\hline 2 & 45.72 & 111 & 105 & 116 & 132 & 124 & 121 & 138 & 147 & 144 \\
\hline 1 (Bottom) & 15.24 & 107 & 101 & 113 & 128 & 123 & 150 & 134 & 146 & 140 \\
\hline Total & 381.0 & & & & & & & & & \\
\hline
\end{tabular}


Table 3. Fuel assembly cross-section properties

\begin{tabular}{|c|c|c|c|c|c|}
\hline $\begin{array}{l}\text { Cross } \\
\text { section } \\
\text { ID }\end{array}$ & $\begin{array}{l}\text { Number of } \\
\text { fuel pins }\end{array}$ & $\begin{array}{c}\text { Average } \\
\text { enrichment } \\
\left(\text { wt } \%{ }^{235} U\right)\end{array}$ & $\begin{array}{l}\text { Number of } \\
\text { gadolinia pins }\end{array}$ & $\begin{array}{c}\text { Gadolinia } \\
\text { enrichment } \\
\text { (wt \%) }\end{array}$ & $\begin{array}{l}\text { Channel } \\
\text { thickness } \\
\text { (in.) }\end{array}$ \\
\hline 100 & 48 & 0.71 & 0 & 0 & 0.100 \\
\hline 101 & 60 & 0.71 & 0 & 0 & 0.100 \\
\hline 102 & 60 & 3.50 & $4 / 6$ & $5.0 / 4.0$ & 0.100 \\
\hline 103 & 60 & 3.65 & $6 / 6$ & $5.0 / 4.0$ & 0.100 \\
\hline 104 & 60 & 3.65 & $4 / 6$ & $5.0 / 4.0$ & 0.100 \\
\hline 105 & 60 & 3.50 & $7 / 3$ & $5.0 / 4.0$ & 0.100 \\
\hline 106 & 49 & 0.71 & 0 & 0 & 0.100 \\
\hline 107 & 60 & 0.71 & 0 & 0 & 0.100 \\
\hline 108 & 60 & 3.23 & 9 & 3.0 & 0.100 \\
\hline 109 & 60 & 3.37 & $2 / 9$ & $4.0 / 3.0$ & 0.100 \\
\hline 110 & 60 & 3.37 & 9 & 3.0 & 0.100 \\
\hline 111 & 60 & 3.23 & $5 / 4$ & $4 / 3$ & 0.100 \\
\hline 112 & 51 & 0.71 & 0 & 0 & 0.100 \\
\hline 113 & 60 & 0.71 & 0 & 0 & 0.100 \\
\hline 114 & 60 & 3.27 & $4 / 5$ & $5.0 / 4.0$ & 0.100 \\
\hline 115 & 60 & 3.38 & $4 / 5$ & $5.0 / 4.0$ & 0.100 \\
\hline 116 & 60 & 3.27 & 9 & 5.0 & 0.100 \\
\hline 117 & 49 & 0.71 & 0 & 0 & 0.100 \\
\hline 150 & 60 & 0.71 & 0 & 0 & 0.100 \\
\hline 118 & 60 & 3.45 & 9 & 4.0 & 0.100 \\
\hline 119 & 60 & 3.62 & $2 / 9$ & $5.0 / 4.0$ & 0.100 \\
\hline 120 & 60 & 3.62 & 9 & 4.0 & 0.100 \\
\hline 121 & 60 & 3.45 & $5 / 4$ & $5.0 / 4.0$ & 0.100 \\
\hline 122 & 51 & 0.71 & 0 & 0 & 0.100 \\
\hline 123 & 60 & 0.71 & 0 & 0 & 0.100 \\
\hline 124 & 60 & 3.39 & 7 & 4.0 & 0.100 \\
\hline 125 & 60 & 3.50 & 9 & 4.0 & 0.100 \\
\hline 126 & 60 & 3.50 & 7 & 4.0 & 0.100 \\
\hline 127 & 51 & 0.71 & 0 & 0 & 0.100 \\
\hline 128 & 60 & 0.71 & 0 & 0 & 0.100 \\
\hline 129 & 60 & 3.39 & $2 / 5$ & $4.0 / 3.0$ & 0.100 \\
\hline 130 & 60 & 3.50 & $4 / 5$ & $4.0 / 3.0$ & 0.100 \\
\hline 131 & 60 & 3.50 & $2 / 5$ & $4.0 / 3.0$ & 0.100 \\
\hline 132 & 60 & 3.39 & 7 & 4.0 & 0.100 \\
\hline 133 & 51 & 0.71 & 0 & 0 & 0.100 \\
\hline 134 & 60 & 0.71 & 0 & 0 & 0.100 \\
\hline 135 & 60 & 3.46 & 7 & 4.0 & 0.100 \\
\hline 136 & 60 & 3.58 & $2 / 7$ & $5.0 / 4.0$ & 0.100 \\
\hline 137 & 60 & 3.58 & 7 & 4.0 & 0.100 \\
\hline 138 & 60 & 3.46 & $4 / 3$ & $5.0 / 4.0$ & 0.100 \\
\hline 139 & 50 & 0.71 & 0 & 0 & 0.080 \\
\hline 140 & 60 & 0.71 & 0 & 0 & 0.080 \\
\hline 141 & 60 & 3.63 & 8 & 4.0 & 0.080 \\
\hline 142 & 60 & 3.88 & $2 / 8$ & $5.0 / 4.0$ & 0.080 \\
\hline 143 & 60 & 3.88 & 8 & 4.0 & 0.080 \\
\hline 144 & 60 & 3.63 & 8 & 5.0 & 0.080 \\
\hline 145 & 48 & 0.71 & 0 & 0 & 0.080 \\
\hline 146 & 60 & 0.71 & 0 & 0 & 0.080 \\
\hline 147 & 60 & 3.63 & 10 & 5.0 & 0.080 \\
\hline 148 & 60 & 3.90 & 12 & 5.0 & 0.080 \\
\hline 149 & 60 & 3.90 & 10 & 5.0 & 0.080 \\
\hline
\end{tabular}




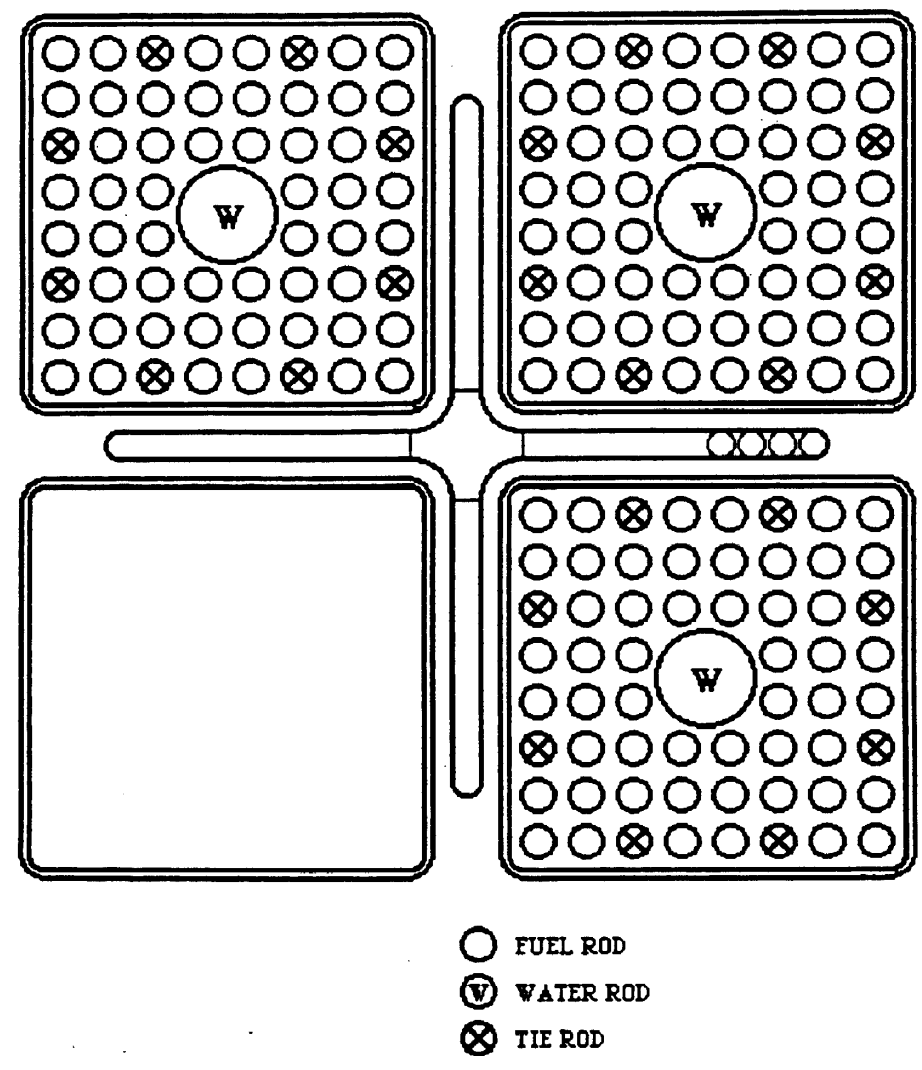

Fig. 1. GE8 $\times 8 \mathrm{NB}$ assemblies and control blade arrangement. 


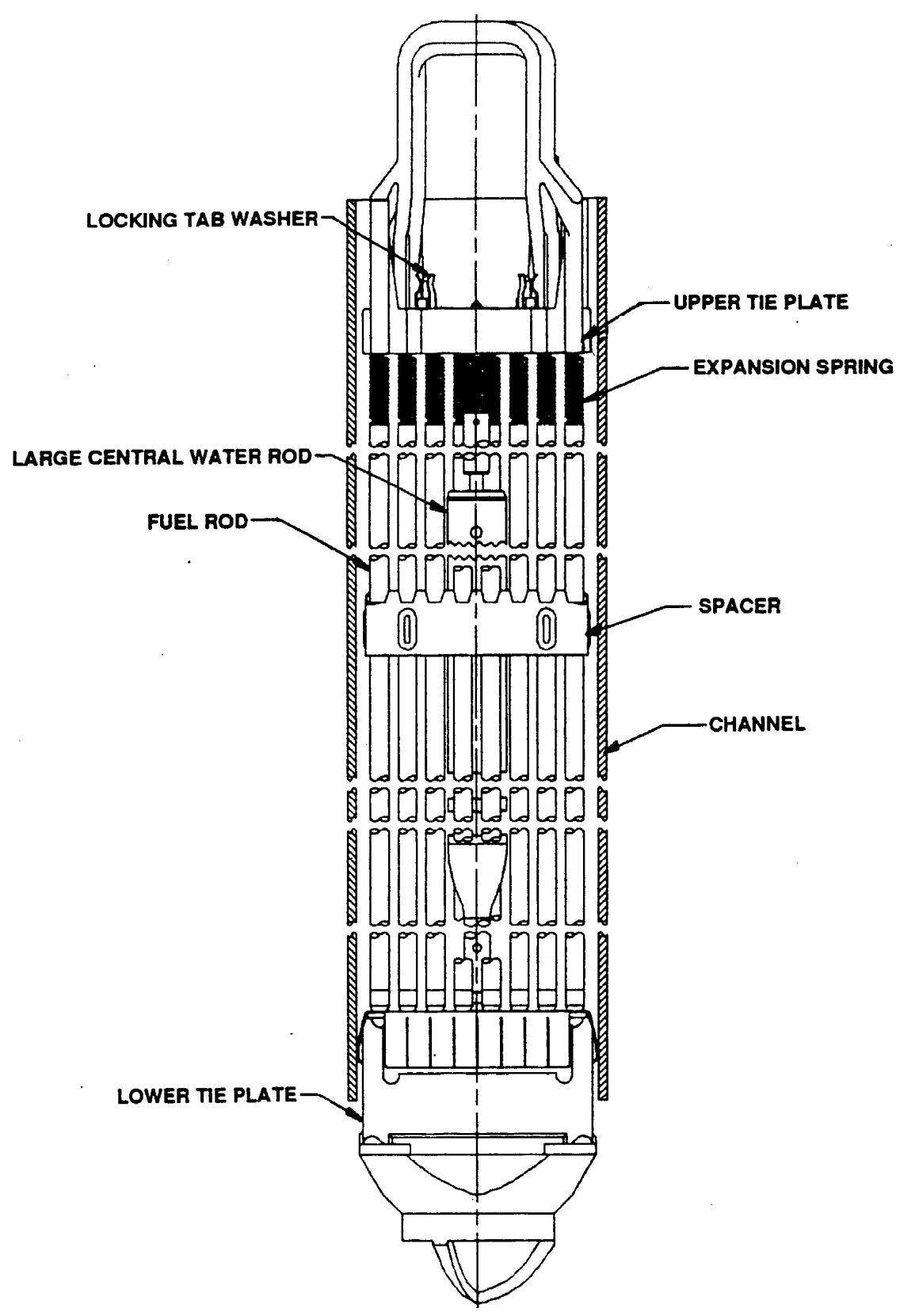

Fig. 2. GE8 $\times 8$ NB assembly axial section. 


\subsection{CONTROL BLADES}

The control blades used in LS1 during the statepoint criticals are bottom-entry blades having a cruciform shape (see Fig. 1). Each control blade has 84 stainless steel tubes containing $\mathrm{B}_{4} \mathrm{C}$ as the active absorbing material. The reactor contains a total of 185 control blades, sufficient to cover most of the assembly groups (4 assemblies) in the core. The control-blade specifications were obtained from EPRI Report NP-240 (ref. 4) and are listed in Table 4. The control-blade design is shown in Fig. 3 and the arrangement of the blades with respect to the reactor core (bottom entry) is shown in Fig. 4

In general, criticality is achieved with about 70 to $75 \%$ blade insertion (i.e., 25 to $30 \%$ of the blades withdrawn) for the cold critical conditions of the statepoint measurements. During full-power operation, however, significantly fewer control blades are required due to the changes in reactor conditions.

Table 4. Control blade specifications

\begin{tabular}{lc}
\hline \multicolumn{1}{c}{ Parameter } & Specification \\
\hline Shape & Cruciform \\
Structural material & $\mathrm{SS}-304$ \\
Control material & $\mathrm{B}_{4} \mathrm{C}$ in SS-304 tubes \\
$\mathrm{B}_{4} \mathrm{C}$ density $\left(\mathrm{g} / \mathrm{cm}^{3}\right)$ & $\left(0.706 \mathrm{H} 2.52 \mathrm{~g} / \mathrm{cm}^{3}\right)$ \\
& Natural abundance \\
Boron isotopic distribution & $70.6 \%$ theoretical density ${ }^{3}$ \\
& ${ }^{10} \mathrm{~B}(18.431 \mathrm{wt} \%),{ }^{11} \mathrm{~B}(81.569 \mathrm{wt} \%)$ \\
Active control length $(\mathrm{cm})$ & 363.2 \\
Number of tubes per control blade group & $84(21$ per individual blade $)$ \\
Inner diameter of $\mathrm{B}_{4} \mathrm{C}$ tubes $(\mathrm{mm})$ & 3.505 \\
Outside diameter of tube sheath $(\mathrm{mm})$ & 4.775 \\
Control blade full thickness $(\mathrm{mm})$ & 7.925 \\
Control blade full span - from center $(\mathrm{mm})$ & 123.83 \\
Control blade sheath thickness $(\mathrm{mm})$ & 1.422 \\
Control blade inner thickness $(\mathrm{mm})$ & 5.081 \\
Control blade inside length $(\mathrm{mm})$ & 102.55 \\
\hline
\end{tabular}




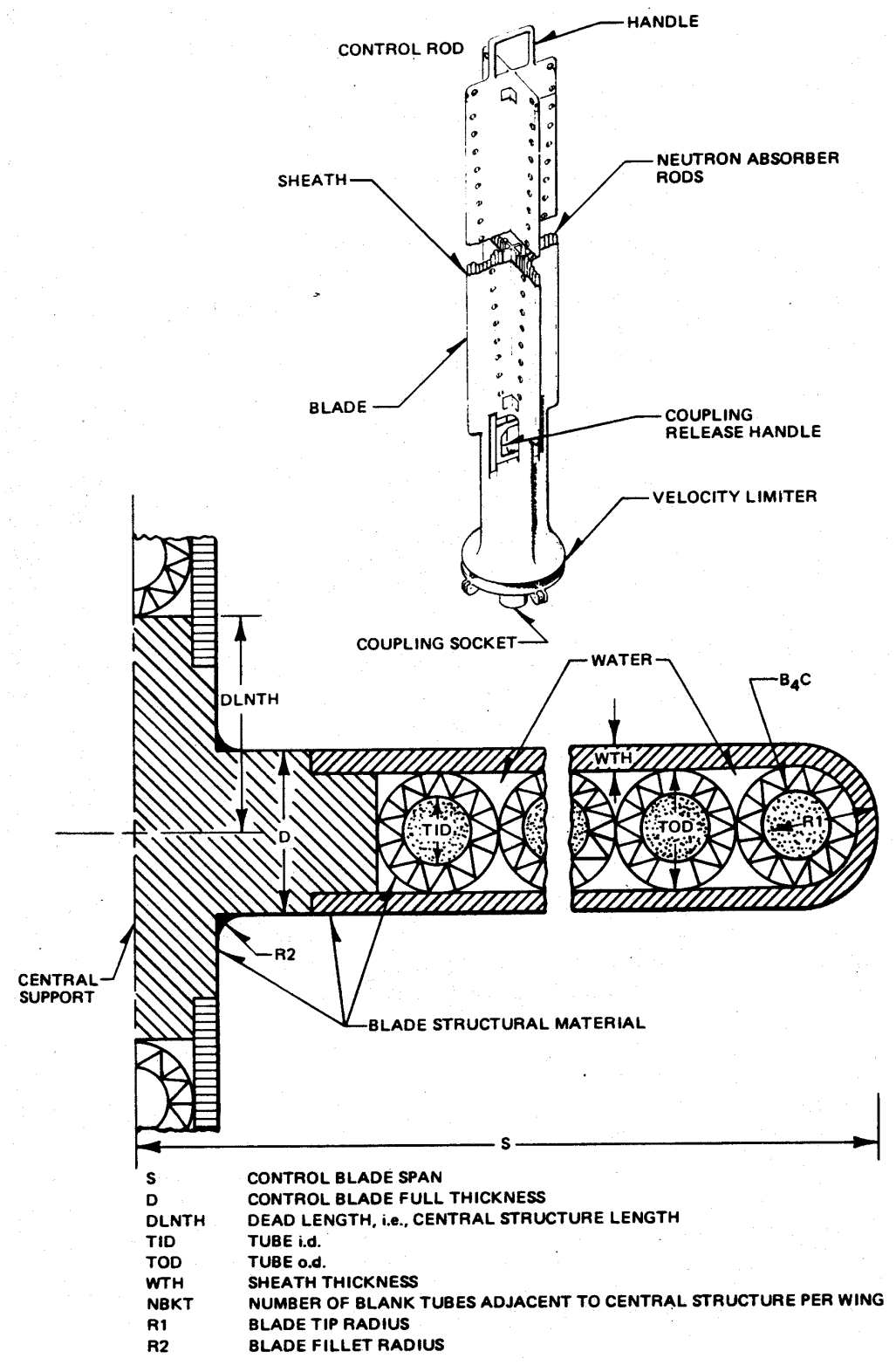

Fig. 3. $\mathrm{B}_{4} \mathrm{C}$ control-blade assembly. 


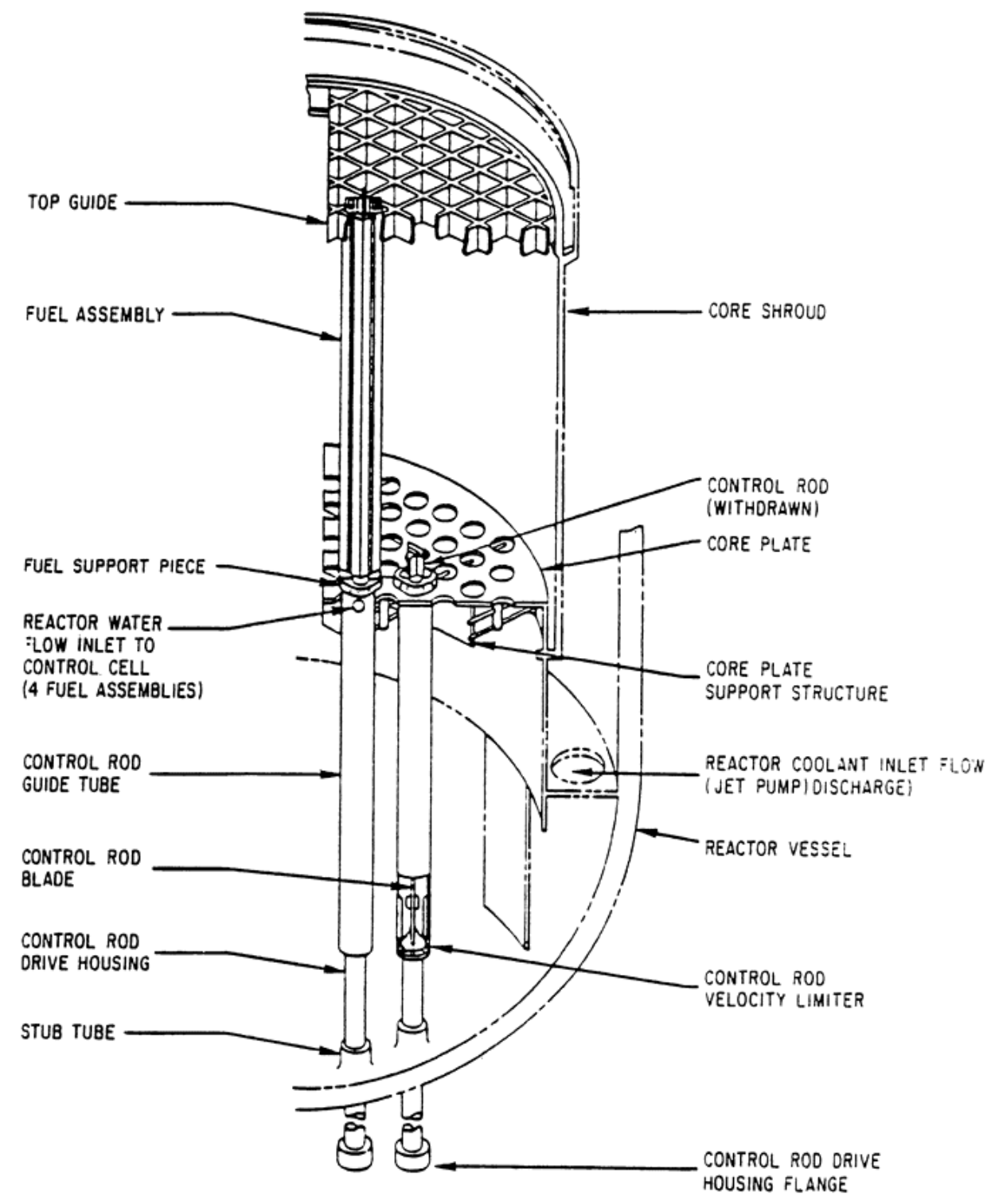

Fig. 4. LS1 reactor core structure and control-blade arrangement. 



\section{LASALLE UNIT 1 CRITICAL STATEPOINT DATA}

A reactor SP is defined as a point at which a reactor first achieves criticality during the startup (e.g., the critical state at the BOC or a restart during cycle operation). For restarts, these points are obtained after sufficient time following a reactor trip to allow the transient fission product xenon poison to decay. The reactor is considered to be at zero power at the statepoint, and thus there is no appreciable buildup of short-lived fission products associated with normal reactor operation. The reactor coolant temperature at the statepoints, and therefore the density, is also more closely associated with cold conditions than normal operating conditions.

\subsection{REACTOR STATEPOINT CONDITIONS}

This report assesses five reactor statepoints measured for the LS1 reactor. The SP data include the BOC of Cycle 7, two restarts during Cycle 7, the BOC for Cycle 8, and one restart during Cycle 8. A summary of the measured reactor conditions at each of the five reactor statepoints (designated SP7 - SP11) is provided in Table 5. The cycle number, the effective full-power days (EFPDs) during the cycle at which the startup occurred, the elapsed time since the reactor was shutdown, moderator temperature, and measured neutron multiplication factor (slightly supercritical based on the reactor period at the time of the statepoint), are provided for each statepoint.

\subsection{FUEL ASSEMBLY CONFIGURATION}

The LS1 reactor core contains a total of 764 fuel assemblies. The core loading configuration is approximately eighth-core symmetric, in general, because the control blades are moved in eighth-core symmetry. The analysis applied core symmetry to reduce the number of assemblies required for the depletion calculations from 764 to 119 assemblies for the Cycle 7 statepoints, and 116 assemblies for the Cycle 8 statepoints. The LS1 assembly configuration for the Cycle 7 statepoint criticals is shown in Fig. 5, and the configuration for the Cycle 8 statepoints is shown in Fig. 6. The nonsymmetric assemblies are shown explicitly in the quarter-core layout in the figures. The assembly sites shown in these figures with no assembly designation are eighth-core symmetric. The assembly types for each alphanumeric designation are defined in Table 2.

\subsection{CONTROL CONFIGURATION}

Figures 7 through 11 provide the LS1 core maps with the control blade group positions for each statepoint. Each box in the figures represents a control blade site (see Fig. 1) that includes four fuel assemblies.

The control blade positions in these figures are given in units of "notches" withdrawn. A notch represents $7.62 \mathrm{~cm}$ ( 3 in.) of blade movement. A " 0 " in a control blade site indicates the blade is fully inserted (from the bottom), with the bottom of the blade aligned with the bottom of the active fuel assembly. A total of 48 notch positions represent $365.8 \mathrm{~cm}$; of axial control blade 
coverage. The total active fuel length is $381.0 \mathrm{~cm}$; therefore, with the blades fully inserted, the upper $15.2 \mathrm{~cm}$ of the fuel is not bladed. This portion of the GE8 $\times 8 \mathrm{NB}$ assemblies contains only natural enrichment uranium fuel. A control blade at position 20 indicates the blades are withdrawn, or lowered, 20 notches $(152.4 \mathrm{~cm})$ below the fully inserted position. A double-dash "--" in a control blade site represents a blade that is fully withdrawn. In general, about 140 of the 185 total control blades are fully inserted in the core at statepoint criticality.

Table 5. Statepoint criticality data

\begin{tabular}{ccccrrrrr}
\hline $\begin{array}{c}\text { State } \\
\text { point }\end{array}$ & Cycle & $\begin{array}{c}\text { Criticality } \\
\text { date } \\
(\mathrm{m} / \mathrm{d} / \mathrm{y})\end{array}$ & $\begin{array}{c}\text { Burnup } \\
(\mathrm{MWd} / \mathrm{MTU})\end{array}$ & \multicolumn{1}{c}{ EFPD } & \multicolumn{1}{c}{$\begin{array}{c}\text { Down } \\
\text { time }\end{array}$} & $k_{\text {eff }}{ }^{a}$ & $\begin{array}{c}\text { Moderator } \\
\text { temperature } \\
(\mathrm{K})\end{array}$ & $\begin{array}{c}\text { Reactor } \\
\text { period } \\
(\mathrm{s})\end{array}$ \\
\hline SP7 & 7 & $06 / 24 / 94$ & 0.00 & 0.00 & 3024 & 1.00584 & 330.2 & 147 \\
SP8 & 7 & $02 / 14 / 95$ & 4728.4 & 193.20 & 120 & 1.00519 & 369.3 & 166 \\
SP9 & 7 & $06 / 17 / 95$ & 7507.28 & 306.75 & 140 & 1.00875 & 378.4 & 420 \\
SP10 & 8 & $04 / 21 / 96$ & 0.00 & 0.00 & 2064 & 1.00605 & 342.5 & 130 \\
SP11 & 8 & $05 / 16 / 96$ & 89.8 & 3.67 & 120 & 1.00574 & 351.2 & 327 \\
\hline
\end{tabular}

${ }^{\mathrm{a}} k_{\text {eff }}$ determined from the measured reactor period. 


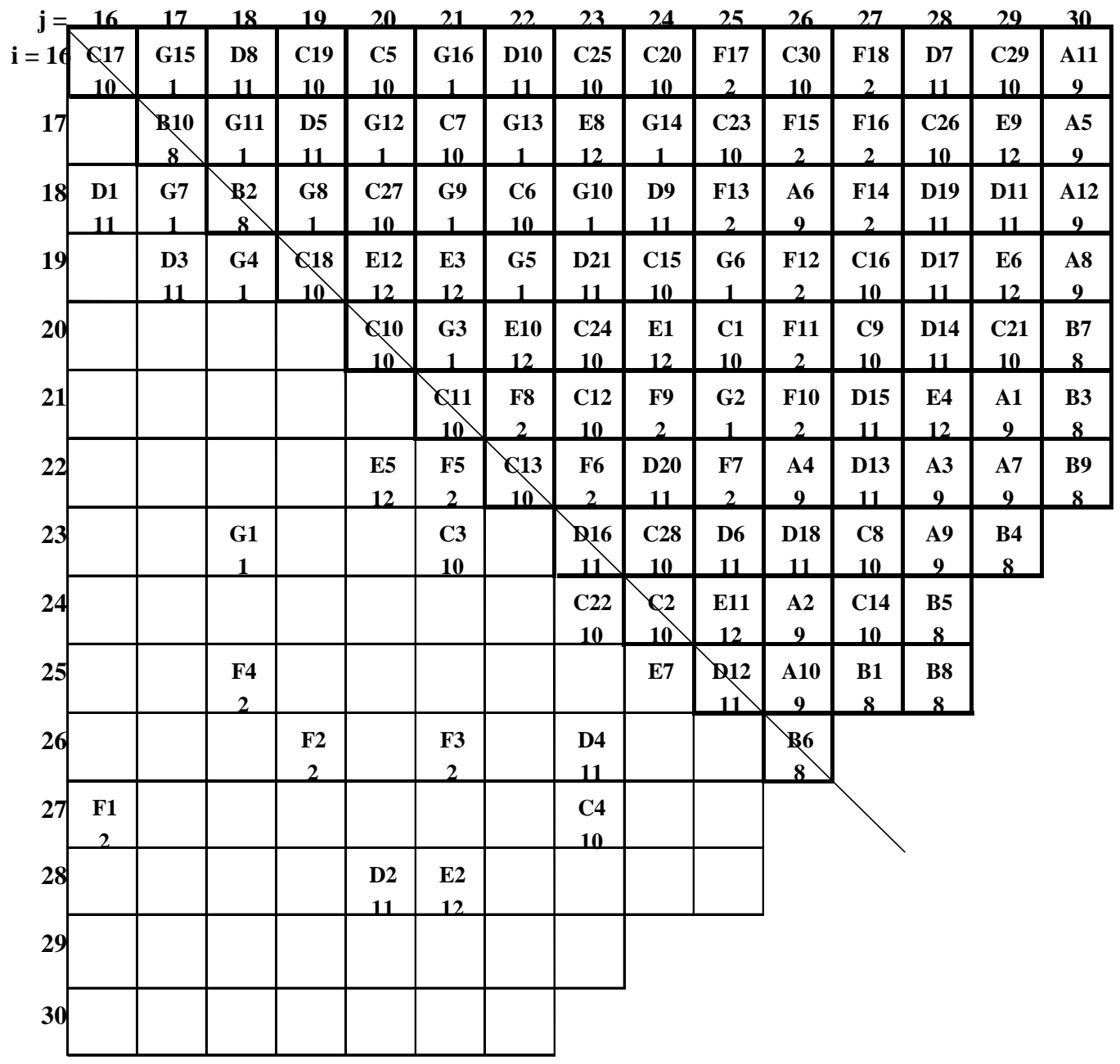

Fi Fuel Assembly Designation ( $\mathrm{Fi}$ and Gi are fresh fuel assemblies in Cycle 7)

$\mathrm{N}$ Fuel Type (Types 1 and 2 are fresh fuel assemblies in Cycle 7)

Fig. 5. LS1 assembly locations for the Cycle 7 statepoint criticals. 


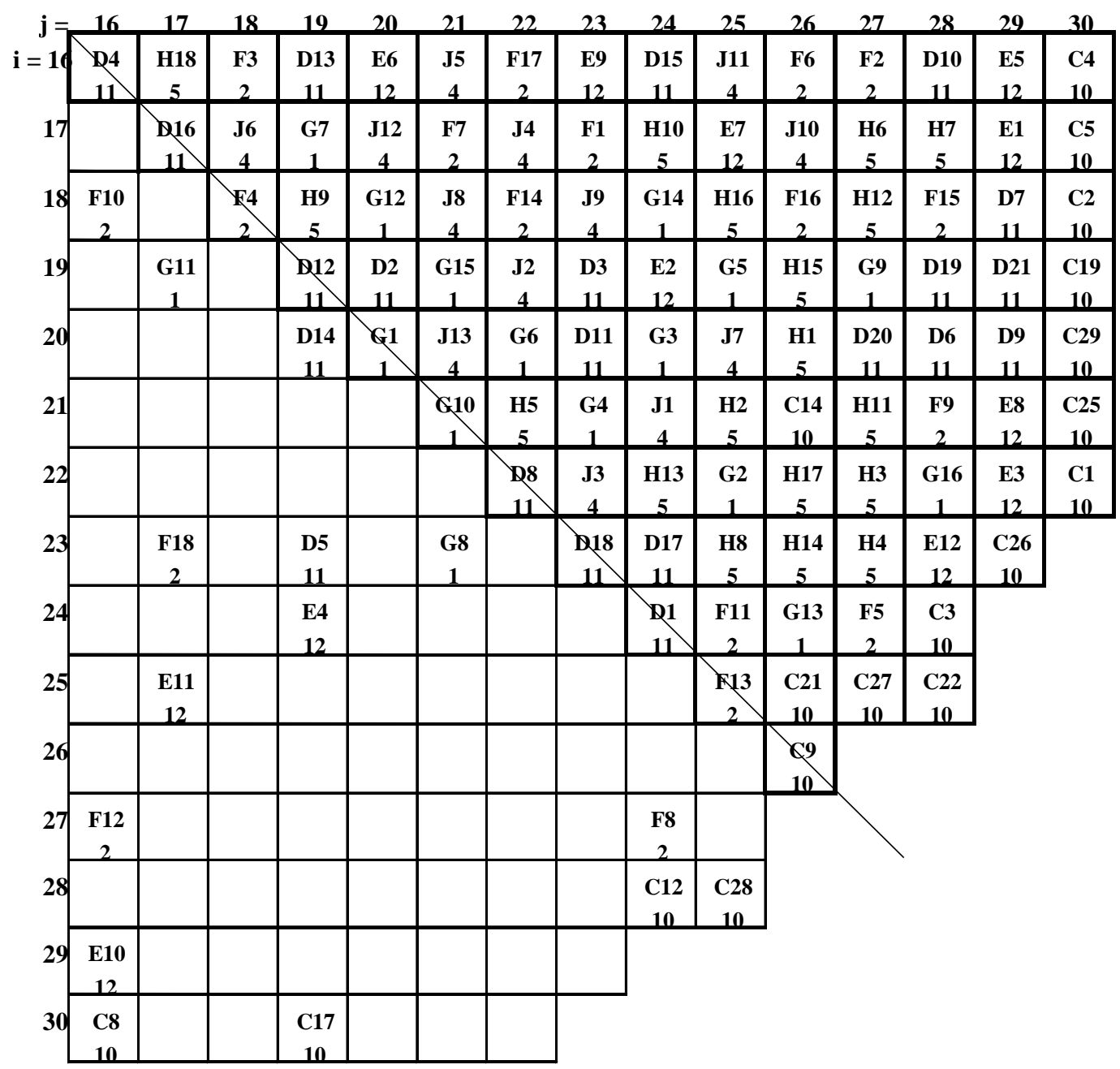

Fi Fuel Assembly Designation ( $\mathrm{Hi}$ and $\mathrm{Ji}$ are fresh fuel assemblies in Cycle 8) $\mathrm{N}$ Fuel Type (Types 4 and 5 are fresh fuel assemblies in Cycle 8)

Fig. 6. LS1 assembly locations for the Cycle 8 statepoint criticals. 


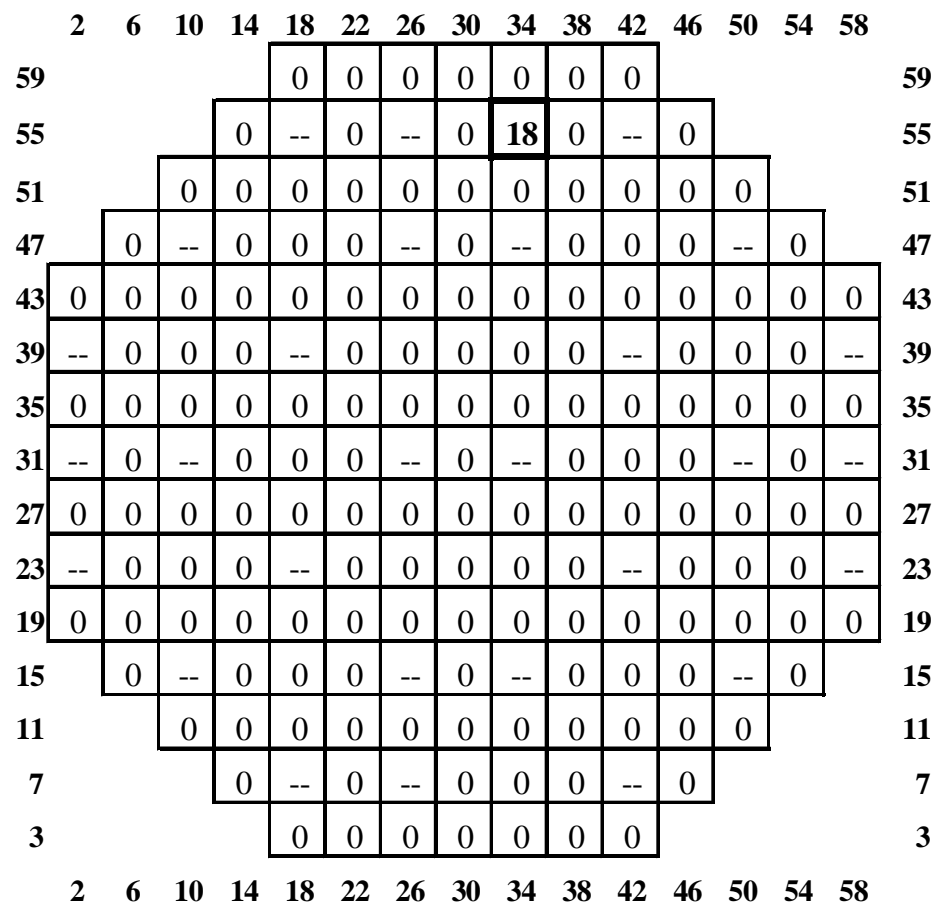

Fig. 7. LS1 SP7 criticality control-blade configuration.

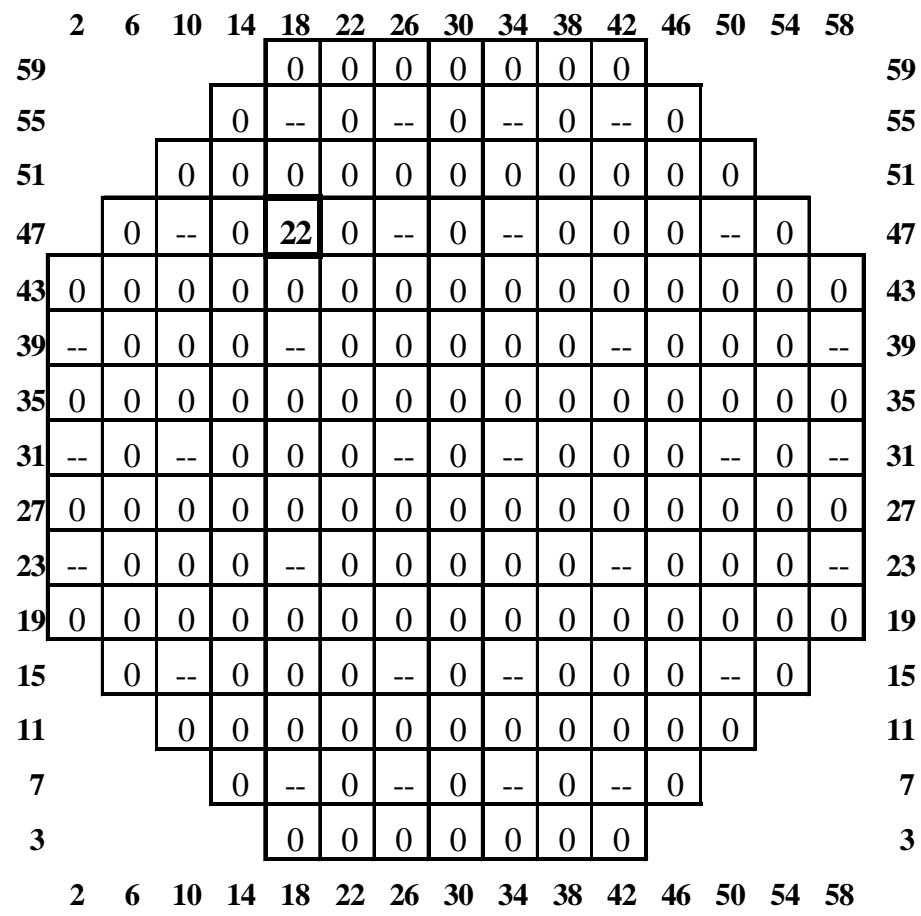

Fig. 8. LS1 SP8 criticality control-blade configuration. 


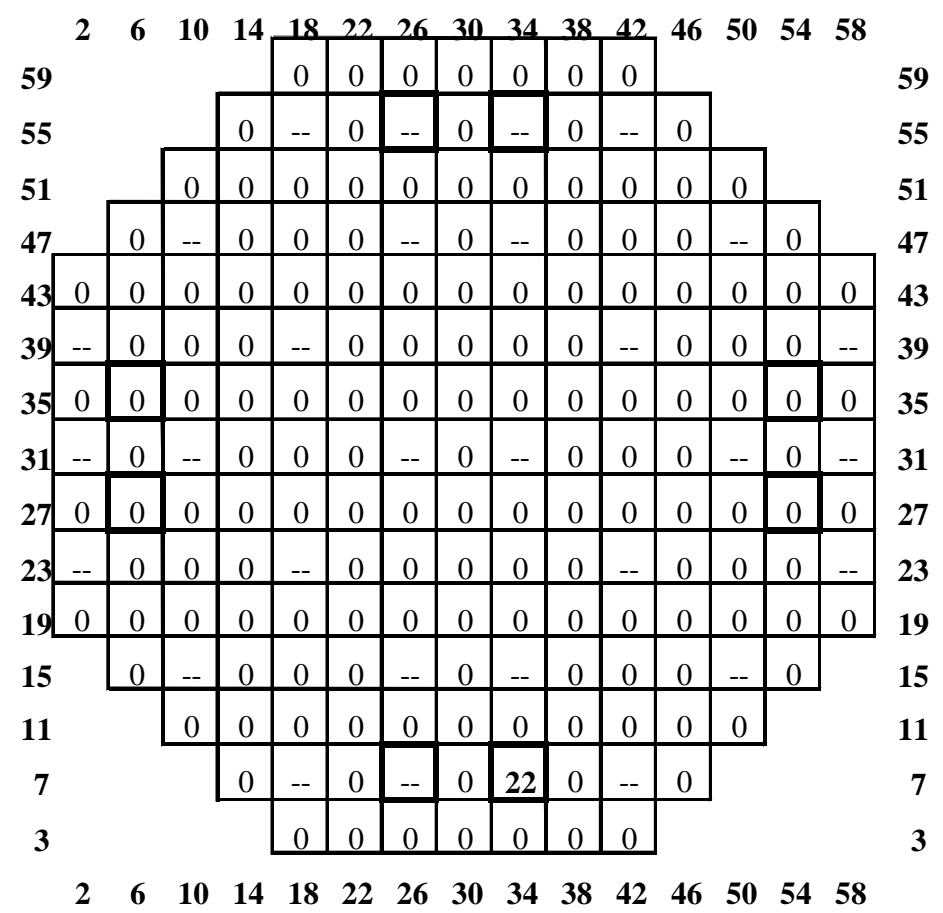

Fig. 9. LS1 SP9 criticality control-blade configuration.

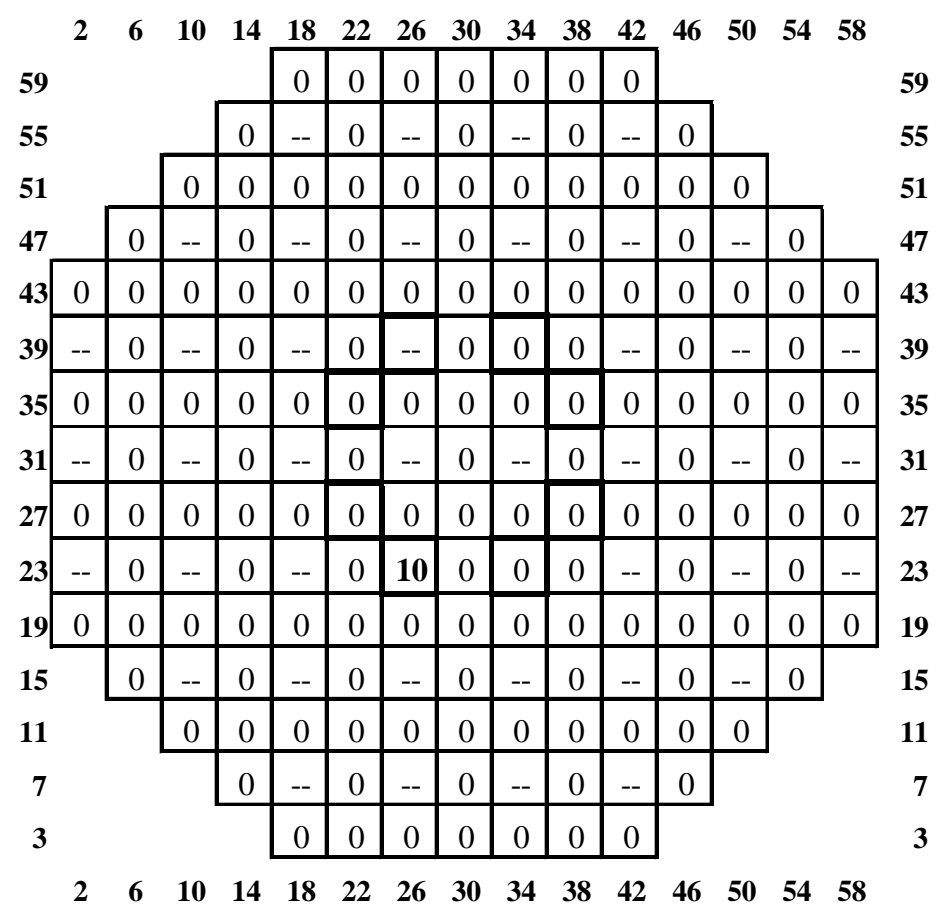

Fig. 10. LS1 SP10 criticality control-blade configuration. 


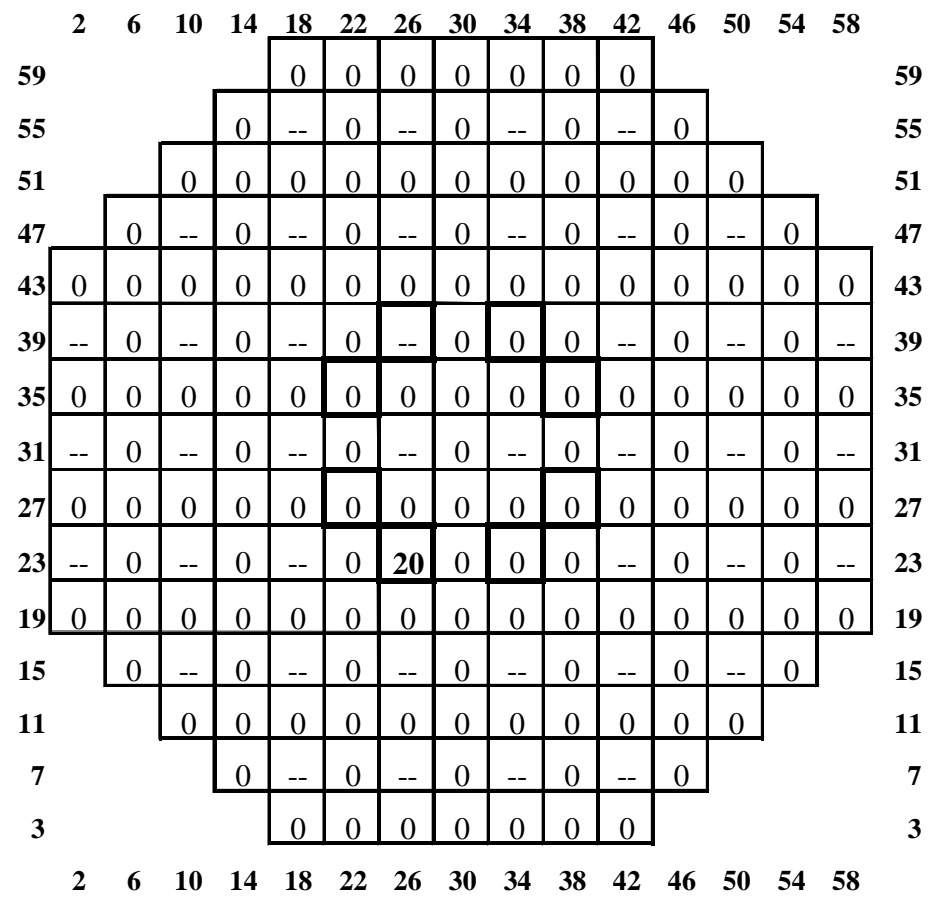

Fig. 11. LS1 SP11 criticality control-blade configuration. 



\section{CRITICALITY ANALYSES}

This section discusses the KENO V.a criticality analysis models, fuel assembly composition data processing, cross-section processing, and the approximations used in the criticality analysis of the LS1 statepoint critical configurations.

\subsection{OVERVIEW OF THE METHODOLOGY}

The reactor criticality analyses were performed using a full-core model of the LS1 reactor with the Monte Carlo criticality code KENO V.a and the 44GROUPNDF5 cross-section library. ${ }^{5}$ The quasi eighth-core symmetry applied in the calculation of the irradiated fuel assembly compositions was also applied in the criticality calculations. This method reduced the number of unique assemblies from 764 to 119 for the Cycle 7 criticals, and 116 for the Cycle 8 criticals. The axial burnup variation of the assemblies was represented using 10 axial zones. Each criticality calculation therefore involved approximately 1200 unique-composition assembly zones.

Irradiated fuel compositions were not calculated as part of this study, but were generated by the Yucca Mountain Project Waste Package Design team. ${ }^{6}$ The depletion calculations were made using the SAS2H sequence of the SCALE 4 code system. These calculations followed the complete irradiation history for the assemblies that resided in the core for each of the SP measurements, during all cycles leading up to the measurements. The composition data were transmitted as data files consisting mainly of ORIGEN-S output for each fuel zone of each assembly.

The criticality analysis methodology involved the following steps:

1. obtaining the irradiated fuel assembly nuclide compositions from the data files,

2. processing the data into units and formats suitable for input to the SCALE Material Information Processor routines,

3. generating cross sections for each assembly axial zone based on the zone compositions and geometry using the Critical Safety Analysis Sequence CSASI,

4. preparing the KENO V.a full-core model based on the assembly locations and control blade configurations for the statepoints, and

5. using the KENO V.a model to calculate the effective multiplication factor $k_{\text {eff }}$ for the system, and compare the results against the measured value.

\subsection{CODE VERSIONS AND COMPUTER PLATFORM}

The cross-section processing and criticality calculations were performed using the SCALE 4.4 code system, run on a DEC Alpha Workstation. Cross-section processing was performed using CSASI, version 4.3, and criticality calculations were performed using KENO V.a, version 4.1. 


\subsection{LS1 FUEL ASSEMBLY COMPOSITIONS}

The fuel assembly compositions for each axial zone of the unirradiated fuel assemblies in the BOC critical configurations (SP7 and SP10) were obtained from the assembly composition data in Tables 2 and 3 All other assembly compositions were obtained from ref. 6.

The assembly locations in the Cycles 7 and 8 statepoint criticals are shown in the quarter-core layout in Figs. 5 and 6, respectively. The Cycle 7 core had 208 fresh fuel assemblies of type $\mathrm{F}$ and $\mathrm{G}$; the Cycle 8 core had 248 fresh assemblies of type $\mathrm{H}$ and $\mathrm{J}$. The assembly sites in these figures that have no assembly designation are symmetric in the oneeighth core. The nonsymmetric assemblies are shown in the lower quadrant of the core layout and were explicitly represented in the criticality model. Even though the reactor is quarter-core assembly symmetric, the KENO V.a model used in the analyses was based on a full-core representation in order to accurately capture the nonsymmetric control blade configuration.

\subsection{COMPOSITION DATA PROCESSING}

The irradiated fuel compositions 6 were calculated by ORIGEN-S and archived primarily as the SAS2 $\mathrm{H}^{7}$ input and ORIGEN-S ${ }^{8}$ output files, for each axial fuel zone of each fuel assembly. These files were processed as part of this work to extract the inventories into a format suitable for input to $\mathrm{CSASI}^{9}$ cross-section processing sequence and ultimately for use the criticality calculation using KENO V.a.

The mass (gram) inventories from the ORIGEN-S calculations were extracted from the output files and processed into atomic number densities using a utility code GECKO (Get

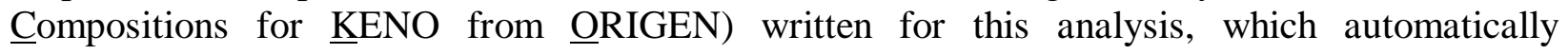
determined the total fuel volume for the case from the number of pins per assembly, the active fuel length, and fuel pin diameter. A listing of this utility is provided in Appendix B. The gram inventories represent the average compositions over all fuel pins, including any integrated burnable poison pins in the assembly. The gram quantities (M) were converted to atom density $(\mathrm{ADEN})$ in units of atoms/(b-cm) using the equation

$$
\mathrm{ADEN}=\frac{\mathrm{M} \times 0.60225}{\mathrm{AWT} \times \mathrm{V}}
$$

where AWT is the atomic weight for the nuclide, and V is the total fuel volume. A limitation in obtaining the assembly inventories from the ORIGEN-S output files is that the inventories are printed to only two significant figures. This factor could potentially result in an error in composition specification of up to $0.5 \%$ for a given nuclide due to roundoff. For a fissile actinide such as ${ }^{235} \mathrm{U}$, this could result in an error in the neutron multiplication factor, where the calculational biases are typically at the percent level. It is recommended that either the binary ORIGEN-S composition interface, or the SAS2H card-image interface, be used in future assessments to store fuel compositions. 
Since the number of nuclides in the ORIGEN-S nuclear database is much larger than that in the 44GROUPNDF5 cross-section library used with KENO V.a, automated selection criteria were applied during the processing. The criteria used by GECKO to select the actinide and fission product nuclides from the ORIGEN-S output were:

1. the nuclide must reside on the 44GROUPNDF5 cross-section library, and

2. the atomic number density must be greater than $10^{-8}$ atoms $/(b-c m)$.

For the light-element tables, only gadolinium and europium (decay product) were selected. The burnable poisons are tracked by ORIGEN-S in the SAS2H depletion analysis as light elements, which allows the burnable-poison inventory to be determined separately from fission products for regions containing both burnable poison and fissionable material. This method has a particular importance to BWR-type CRC analyses in that it allows the burnable poison inventory to be determined separately from the fission product gadolinium, and distributed heterogeneously in only the gadolinium poison pins, allowing a more detailed assembly representation for the criticality calculations. To obtain the correct concentrations in the burnable poison rods the volume (V) used to derived the number densities must be adjusted to include only the poison rods.

The initial concentration of oxygen (as ${ }^{16} \mathrm{O}$ in the fuel) was not available from the ORIGEN-S output since it was omitted as a light-element input specification in the SAS2H input. The oxygen was therefore added automatically to each case by the GECKO utility at a fixed nominal atomic number density of $4.5497 \times 10^{-2}$ atoms $/ \mathrm{b}-\mathrm{cm}$.

The water-moderator density for each of the statepoints was based on the statepoint temperatures listed in Table 5 by interpolating on standard density tables for a system pressure of 1000 psia. The moderator densities for the SP7 - SP11 analyses were 0.9882, 0.9649, 0.9583, 0.9818 , and $0.9768 \mathrm{~g} / \mathrm{cm}^{3}$, respectively.

\subsection{CROSS-SECTION PROCESSING}

Neutron cross sections for the criticality analyses were obtained from the SCALE 44GROUPNDF5 library, a 44-group neutron cross-section library based on ENDF/B-V data, with ENDF/B-VI evaluations for ${ }^{16} \mathrm{O},{ }^{154} \mathrm{Eu}$, and ${ }^{155} \mathrm{Eu}$. The 44 GROUPNDF5 library was developed specifically for criticality safety calculations involving LWR fuel.

The cross sections were processed for the KENO V.a criticality analyses using the Criticality Safety Analysis Sequence CSASI, a control sequence within the CSAS4 control module of SCALE. The CSASI sequence uses the BONAMI code to apply the Bondarenko resonance self-shielding method for nuclides with Bondarenko data; it then invokes NITAWL-II to perform Nordheim resolved resonance self-shielding corrections using the specified problem-dependent temperature. The microscopic cross sections for the nuclides in each mixture are subsequently combined in CSASI using the ICE module of SCALE to create a macroscopic cross section for each mixture. This step reduced significantly the number of cross sections handled by KENO V.a for a statepoint calculation.

For each statepoint calculation, approximately 1200 sequential CSASI runs (BONAMI/NITAWL-II/ICE) were performed to generate the macroscopic cross sections for 
each assembly zone. The macroscopic cross sections incorporate the number densities and temperature for each fuel zone, and therefore no composition specifications were required in the KENO V.a case. Following each CSASI run, the WAX utility module was run to assign a unique cross-section identifier to the set based on the assembly ID (e.g., D4, J12, etc.) and axial position, and then append the cross section to a working library to build a single set of cross sections required for the criticality problem.

During the cross-section library processing, an undocumented array dimensional limit was exceeded in WAX, requiring a fix in WAX to handle up to the approximately 2400 cross-section sets needed for the heterogeneous assembly statepoint calculations. A typical CSASI input case, generated by the GECKO utility code, is listed in Appendix A. The GECKO code listing is given in Appendix B.

\subsection{GE8 $\times 8 \mathrm{NB}$ ASSEMBLY MODEL}

The GE8 $88 \mathrm{NB}$ assemblies were assumed to have 60 pins in each axial fuel zone in the KENO V.a model. The natural enrichment uranium zones at each end of the assemblies actually contained between 48 and 60 pins. For these zones the number densities of the fuel were adjusted in order to conserve the total mass of the zone (for fuel zones with less than 60 pins). The actinide and fission product number densities within each zone were assumed to be spatially uniform over all assembly pins, and over the axial zone length.

The gadolinium poison was represented using two different assembly models, one that homogenized the poison in all of the assembly pins, and the other that explicitly represented the burnable poison pins in the assembly. In the homogeneous model, the gadolinium poison was simply distributed uniformly over all 60 pins of the fuel assembly.

In the heterogeneous model the gadolinium poison was placed in a limited number of pins as $\mathrm{UO}_{2} / \mathrm{Gd}_{2} \mathrm{O}_{3}$ pins. The actual number of gadolinia pins per assembly axial zone is provided in Table 3, and ranges from 7 to 12 pins per assembly. However, the exact configuration of the pins in the assembly is proprietary information and was not available to ORNL. For the purposes of this study, the discrete pin model assumed 8 gadolinia pins per assembly in the criticality calculations. The pins were distributed symmetrically in the central ring of fuel pins, near the four corners of the assembly, as shown in Fig. 12. Although this is not the actual pin configuration, this model is assumed to be generally representative of BWR assemblies and sufficient to assess the importance of a heterogeneous poison pin representation for CRC calculations involving gadolinium poison-bearing assemblies.

The number densities of the gadolinium poison isotopes (and europium decay daughters) were calculated by GECKO using an assembly volume based on 8 poison pins per assembly for the heterogeneous assembly model.

The assembly fuel pin spacer grids were not included in the KENO V.a model since there was insufficient design information available to include them. The Zircaloy channels were modeled with a single thickness of $0.203 \mathrm{~cm}(0.08 \mathrm{in}$.), corresponding to the thickness of the Cycle 8 fuel assemblies. 


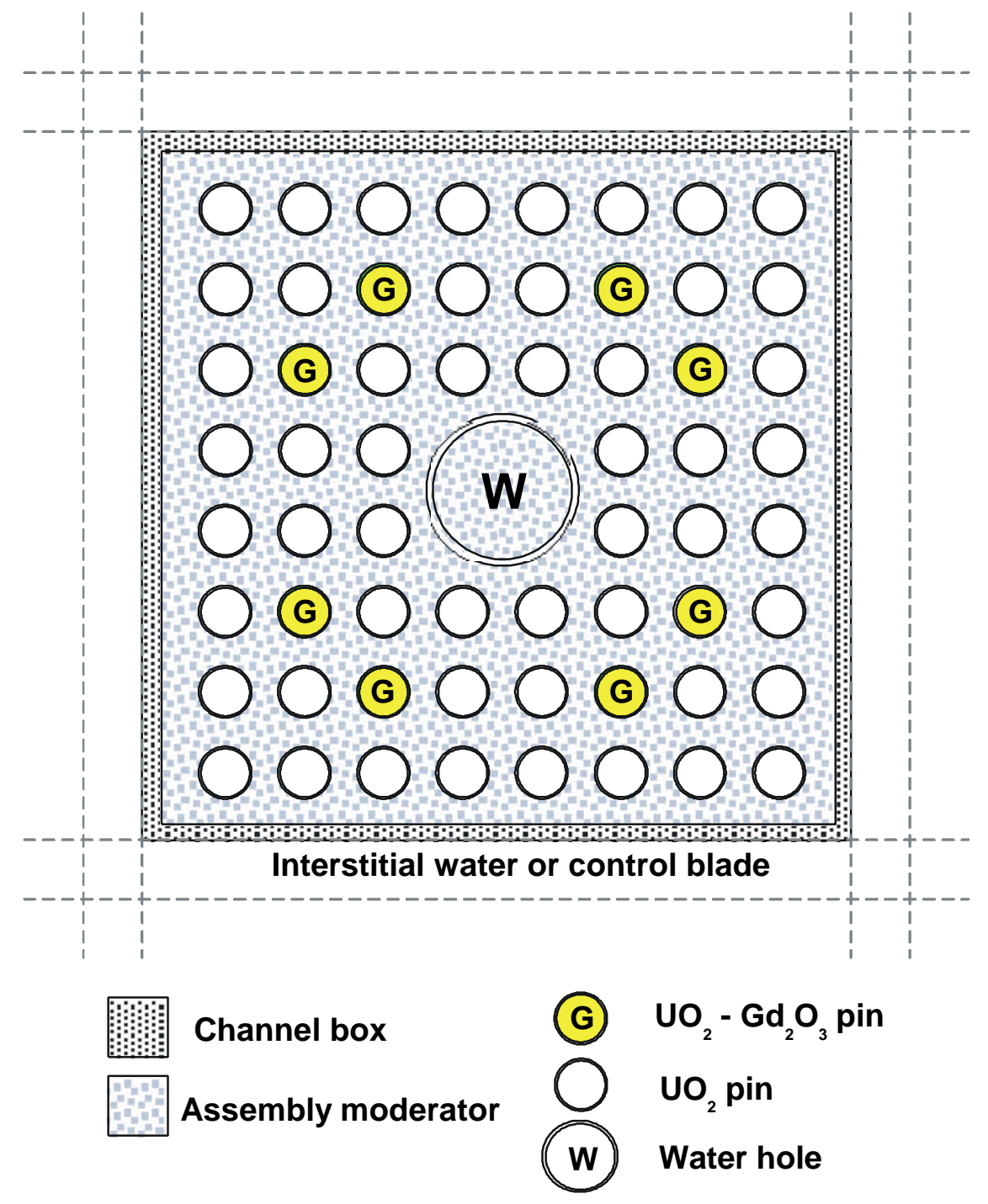

Fig. 12. KENO V.a GE8 $\times 8$ NB assembly model. 


\subsection{LASALLE UNIT 1 REACTOR MODEL}

A KENO V.a full-core model of the LS1 reactor model was developed using the 10 -axial-zone assembly representation adopted in the previous analyses. ${ }^{1}$ The reactor model explicitly represented the 764 fuel assemblies in the core, plus the approximately 140 control blades inserted into the core during the critical measurements. The quasi eighth-core symmetry reduced the number of unique assembly zones (compositions) in the model to about 1200 . For calculations that explicitly represented the burnable gadolinium pins in the assembly (8 pins per assembly), two mixtures per axial fuel zone were required - one for the $\mathrm{UO}_{2}$ pins; the second, for the $\mathrm{UO}_{2} / \mathrm{Gd}_{2} \mathrm{O}_{3}$ pins.

Each assembly axial zone was modeled using 10 units in the KENO V.a model, resulting in a total of about 12,000 units to define the unique assemblies for the problem. In addition, each assembly required 6 array entries to define the fuel pin arrangements, or about 7,000 arrays for the problem. A utility code, LS1K, was written to automate the preparation of the mixture, geometry, and array data blocks for the KENO V.a input. An assembly map with the assembly locations for each statepoint is required by the LS1K utility. The LS1K utility code listing and the assembly map for Cycle 8 are provided in Appendix C.

After constructing the 10 units representing the 10 axial zones of an assembly, the units were stacked in a vertical array to form the complete assembly unit having a length of $381.0 \mathrm{~cm}$. The assembly interstitial water (see Fig. 12) was modeled with units that spanned the full active length of the complete assembly $(381.0 \mathrm{~cm})$. The control blades were constructed with five units each, one for each blade, and one unit at the center of the cruciform. The $21 \mathrm{~B}_{4} \mathrm{C}$ rods in each control blade were modeled explicitly in the control blade models. Two control blade models were assembled - one to represent the fully inserted control blades; the other, to represent the single critical height control blade. An assessment of the impact of approximating the $\mathrm{B}_{4} \mathrm{C}$ rods as a homogeneous mixture (with steel tube sheath and water) within the control blades indicated that homogenization resulted in about a $1 \%$ decrease in the $k_{\text {eff }}$ compared to explicitly modeling the $\mathrm{B}_{4} \mathrm{C}$ rods. A cross-section illustration of the KENO V.a assembly group and control blade model is shown in Fig. 13.

After each unique assembly unit and the interstitial water units were defined, the core configuration was assembled as a $59 \times 59$ unit array using the assembly configurations for the respective cycles (see Figs. 5 and 6). Thirty of the 59 row (and column) positions in the array contain the assembly units, with the remaining 29 units in each assembly row (or column) representing the water units between the assemblies. Between each of the 30 rows containing the assembly units were units containing the interstitial water. The control blade units were subsequently added to the array based on the control blade patterns for each critical statepoint (see Figs. 7 through 11). An abridged KENO V.a model input listed for the Cycle 8 SP11 critical configuration is provided in Appendix D. The total size of the full-core model is about 70,000 lines (not all lines are included in listing). A section view of the reactor core for the Cycle 8 SP11 critical configuration is illustrated in Fig. 14 showing the control blade configuration at a core elevation of $100 \mathrm{~cm}$. A subsection of the KENO V.a core model, obtained using the KENO3D geometry visualization program, is illustrated in Fig. 15. 
The region surrounding the reactor core was not modeled in detail. Due to the large physical size of the reactor core (4.6-m diam), only about $0.5 \%$ of the neutrons leak from the system, and therefore a detailed treatment to accurately model the reflection from the out-of-core components was not warranted for this analysis. For the criticality analysis, the reactor core was surrounded by $30 \mathrm{~cm}$ of water to approximate the reflection conditions close to the core.

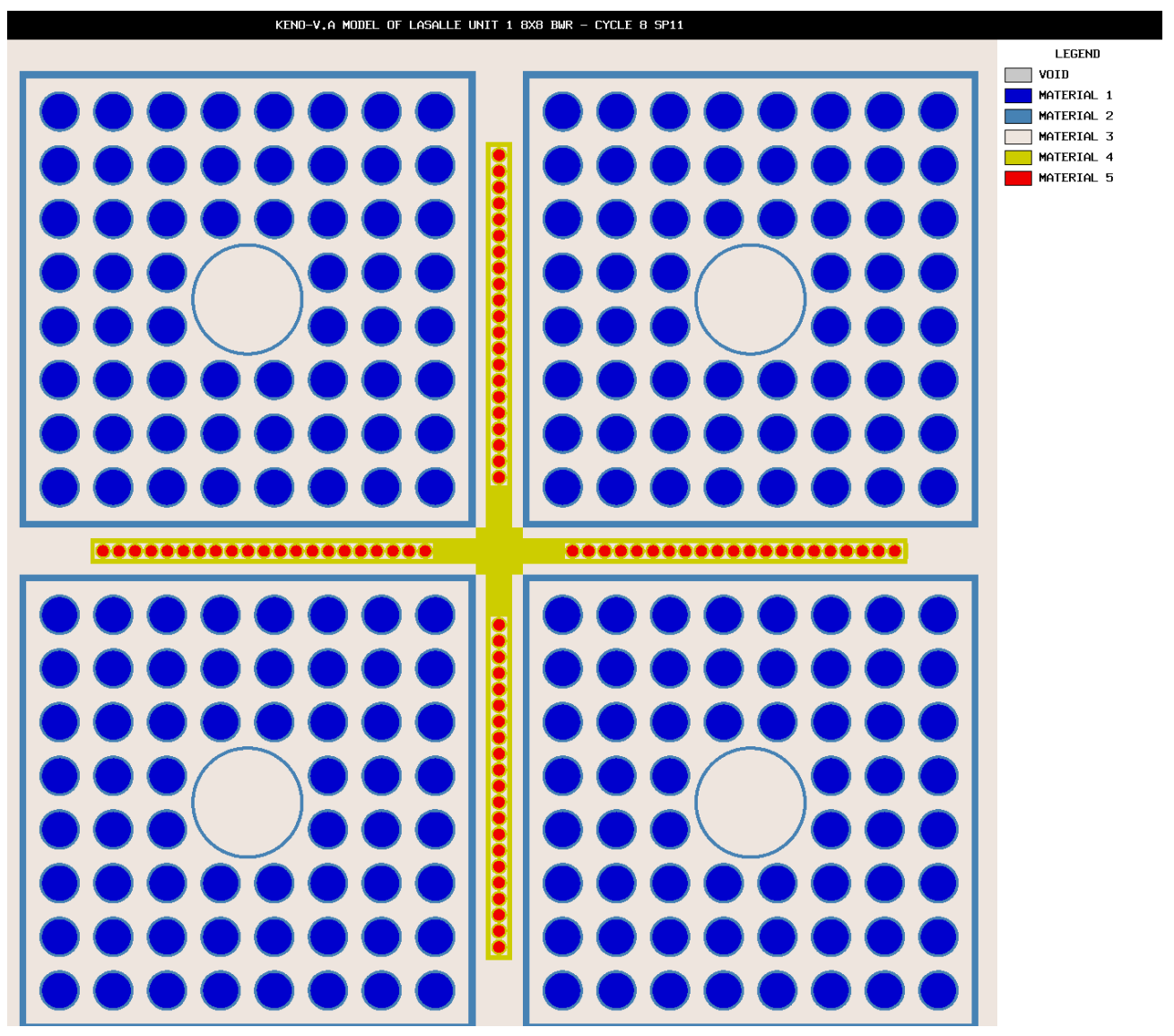

Fig. 13. KENO V.a model of LS1 assembly group and control blades. 


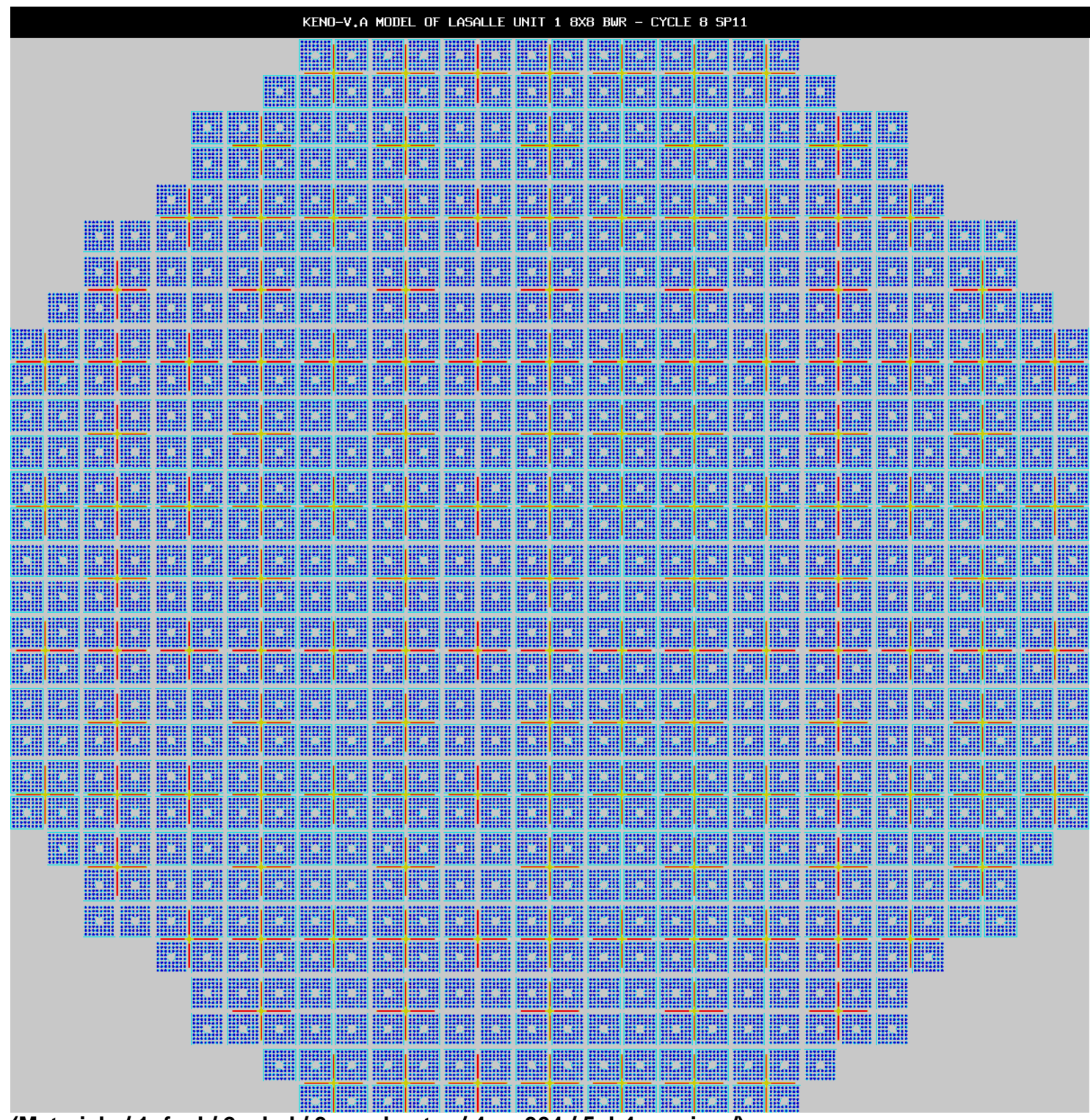

(Materials / 1=fuel / 2=clad / 3=moderator $/ 4=s s 304 / 5=b 4 c$ region $/$ )

Fig. 14. KENO V.a model of the LS1 SP11 critical configuration. 


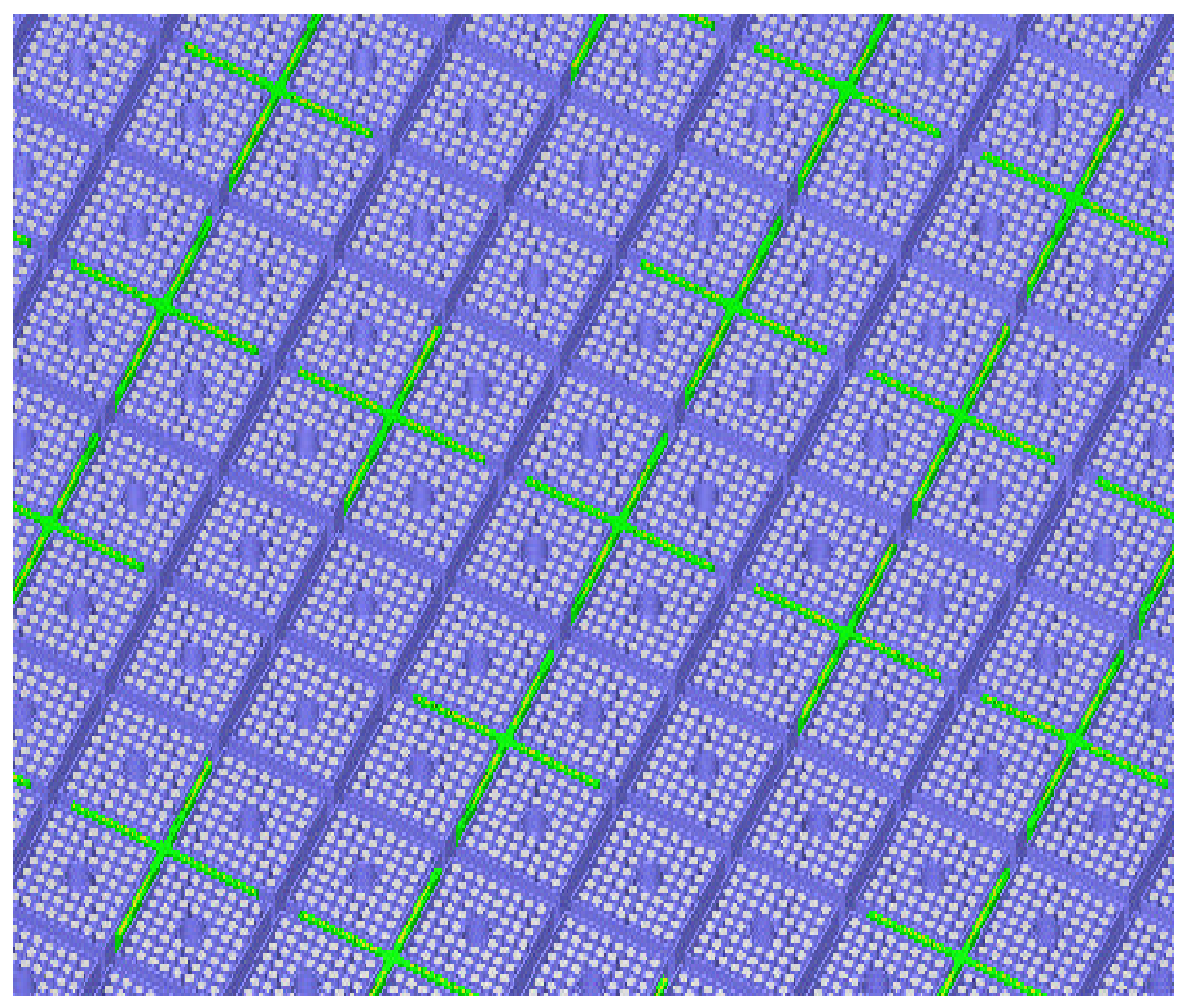

Fig. 15. KENO3D visualization of the LaSalle Unit 1 Reactor - top view. 


\subsection{SUMMARY OF KEY ANALYSIS APPROXIMATIONS}

The key analysis assumptions and modeling approximations in the KENO V.a criticality analysis of the LS1 statepoints are summarized in this section. Since the fuel irradiated compositions were not calculated as part of this work, the approximations and uncertainties do not extend to the depletion analysis methodology. Only the assumptions in the criticality analysis are summarized here. The key modeling assumptions are the following:

1. all assemblies contain 60 pins for all axial zones (assembly mass conserved),

2. the gadolinium poison pins in the enriched uranium assemblies were approximated using a discrete symmetric 8-pin arrangement (see Fig. 12) in all assemblies, and also an homogenized (60-pin) arrangement,

3. uniform actinide and fission product concentrations in all assembly fuel zones (no correction for control blade or gadolinium poison perturbations on fuel compositions),

4. uniform oxygen (as ${ }^{16} \mathrm{O}$ ) concentrations were assumed for all assemblies,

5. fuel assembly pin spacer grids and end region details were not modeled,

6. reactor core reflection was approximated by thick water reflection,

7. channel thickness for the assemblies $\mathbf{H}$ and $\mathbf{J}$ (see Table 3) were assumed to be the same as earlier cycles (assemblies A - K),

8. quarter-core (quasi eight-core) symmetry, and

9. ten axial burnup zones. 


\section{RESULTS AND DISCUSSION}

The neutron multiplication factors $\left(k_{\text {eff }}\right)$ calculated by KENO V.a for each of the five statepoint critical configurations are listed in Table 6. These results are compared against the known $k_{\text {eff }}$ values.

The KENO V.a results are based on 500 generations of 1000 particles per generation, for a total of 500,000 particle histories. The criticality analysis execution time was about 20 minutes CPU time on the DEC Alpha workstation.

The criticality calculations performed using the homogenized model for the gadolinium poison in the assemblies demonstrate that distributing the poison uniformly in all fuel pins results in a substantial underprediction in the system $k_{\text {eff }}$ for most statepoints. The degree of underprediction is most pronounced in the Cycle 8 statepoints, which have a high initial gadolinium poison loading compared with the Cycle 7 statepoints, due to a larger number of fresh assemblies in the BOC core (248 compared to 208) and the higher gadolinium enrichment in the Cycle 8 fresh assemblies. The SP9 measurement, performed at a Cycle 7 burnup of about $8000 \mathrm{MWd} / \mathrm{MTU}$, is accurately predicted by the homogeneous model likely due to the substantial depletion of the initial gadolinium poison loading in the core.

The criticality calculations performed using a heterogeneous symmetric 8-Gd-pin model resulted in a significant improvement in the predicted $k_{\text {eff. }}$ For the middle-of-cycle (MOC) statepoints SP8 and SP9, the predicted $k_{\text {eff }}$ value is within $1 \% \Delta k / k$ of measurement. For the BOC and low-cycle-burnup statepoints SP7, SP10, and SP11, which will have the highest gadolinium poison concentrations, the KENO V.a results are overpredicting by between 1 and $2.3 \% \Delta k / k$.

The discrete gadolinium poison pins were modeled using an 8-pin assembly approximation (Fig. 12) since the actual pin arrangement is proprietary information. The 8-pin configuration was easily implemented due to the assembly symmetry and the number of Gadolinium pins is close to the actual number of pins based on an average over the assemblies in the reactor core. If the average number of gadolinium poison pins is calculated based on the fresh assemblies in the BOC cores (where the majority of the gadolinium poison resides), then the effective average number of pins is estimated to be about 8.3 pins, based on the 208 fresh F- and G-type assemblies in Cycle 7, and about 9.1 pins per assembly based on the 248 fresh $\mathrm{H}$ and J-type assemblies in Cycle 8. The use of 8 pins per assembly in the criticality analysis model, although close to the Cycle 7 average, is less than the average for the Cycle 8 statepoints, and may potentially result in an under-representation of the gadolinium worth in the assemblies.

A detailed assessment of the applicability of using an average number of poison pins to represent all assemblies in the core is beyond the scope of this report. In addition, this report has not addressed the effect of the poison pin arrangement in the assembly compared with the actual assembly arrangements because the assembly configurations are proprietary. Poison pins located

\footnotetext{
* Note that the actual $k_{\text {eff }}$ for the statepoint is slightly greater than 1 , as determined from the reactor period at the statepoint reactor configuration.
} 
in the inner region of the assembly will have a different associated worth compared with pins located near the outer edge of the assembly. Similarly, the pin locations relative to the control blades may also be important.

An additional set of KENO V.a calculations were performed using a 9-pin gadolinium poison pin model, with the additional pin located in the outer ring of pins in the assembly. These calculations were performed for the Cycle 8 statepoints SP10 and SP11 only, because the average number of pins in the Cycle 7 assemblies was closer to 8 pins. The results are plotted in Fig. 16 with the previous results. The two Cycle 8 statepoints are substantially improved with the 9-pin assembly model. The $k_{\text {eff }}$ values, which showed a $2 \%$ discrepancy using the 8-pin representation, are predicted to within about $1 \%$ using the 9-pin approximation, indicating a significant degree of sensitivity to the average number of poison pins associated with the assemblies.

Table 6. Calculated $\boldsymbol{k}_{\text {eff }}$ for LS1 statepoints

\begin{tabular}{ccccccc}
\hline $\begin{array}{c}\text { State } \\
\text { point }\end{array}$ & Cycle & $\begin{array}{c}\text { Cycle } \\
\text { burnup } \\
\text { (MWd/MTU) }\end{array}$ & $\begin{array}{c}\text { Measured } \\
k_{\text {eff }}\end{array}$ & $\begin{array}{c}\text { Calculated } k_{\text {eff }} \\
\text { (homogeneous } \\
\text { Gd model) }\end{array}$ & $\begin{array}{c}\text { Calculated } k_{\text {eff }} \\
\text { (8-pin Gd model) }\end{array}$ & $\begin{array}{c}\text { Calculated } k_{\text {eff }} \\
\text { (9-pin Gd model }- \\
\text { Cycle 8 only) }\end{array}$ \\
\hline SP7 & 7 (BOC) & 0.00 & 1.00584 & $0.9740 \pm 0.0010$ & $1.0163 \pm 0.0009$ & $a$ \\
SP8 & 7 & 4728.4 & 1.00519 & $0.9585 \pm 0.0012$ & $0.9992 \pm 0.0010$ & $a$ \\
SP9 & 7 & 7507.28 & 1.00875 & $1.0029 \pm 0.0010$ & $1.0110 \pm 0.0009$ & $a$ \\
SP10 & 8 (BOC) & 0.00 & 1.00605 & $0.8972 \pm 0.0010$ & $1.0251 \pm 0.0011$ & $1.0154 \pm 0.0009$ \\
SP11 & 8 & 89.8 & 1.00574 & $0.8978 \pm 0.0011$ & $1.0284 \pm 0.0011$ & $1.0175 \pm 0.0009$ \\
\hline
\end{tabular}

${ }^{a}$ Values were not reported. 


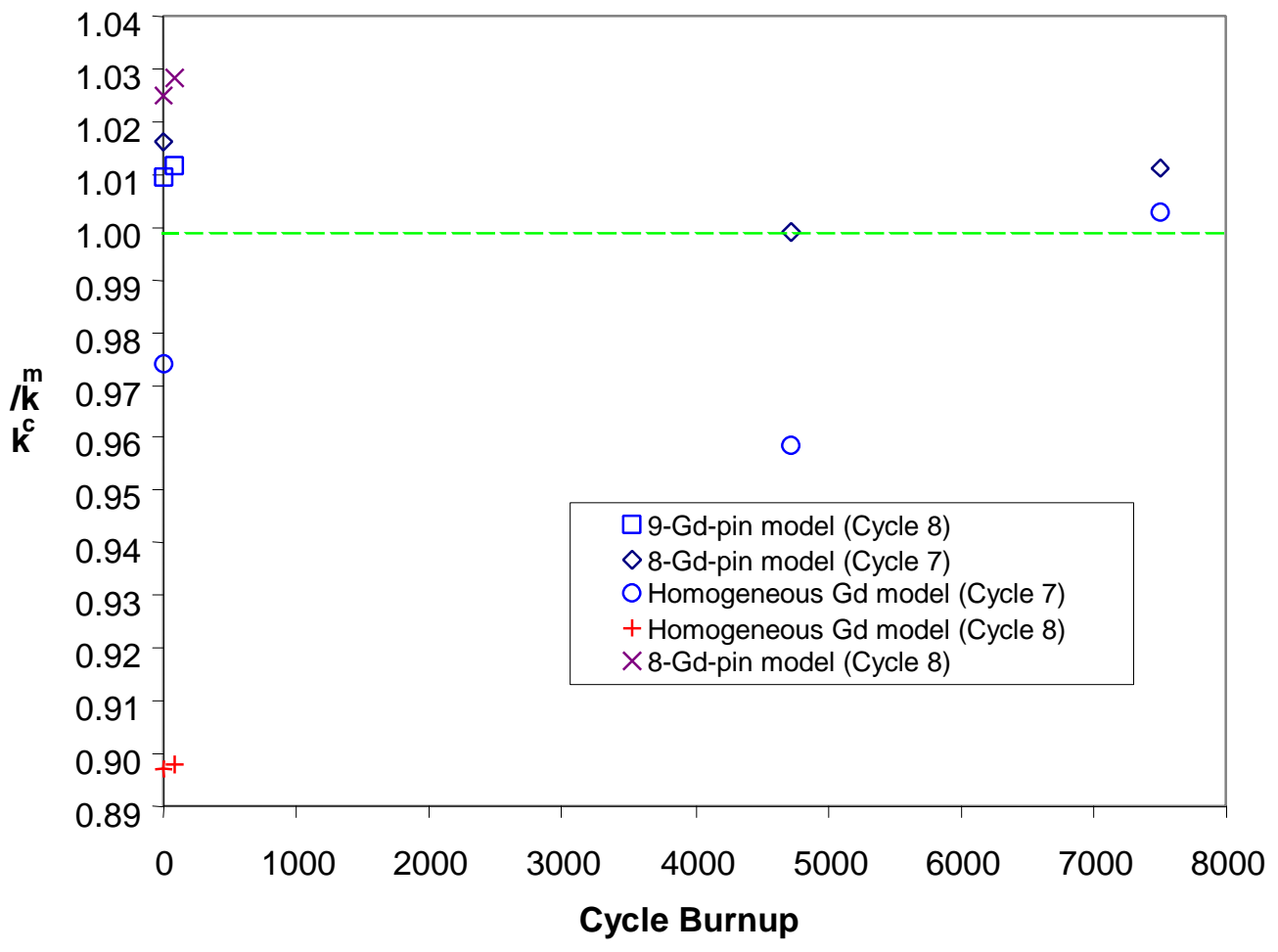

Fig. 16. Calculated $\left(k_{c}\right)$-to-measured $\left(k_{m}\right) k_{e f f}$ values vs cycle burnup. 



\section{CONCLUSIONS}

The KENO V.a Monte Carlo results for five LS1 BWR critical configurations are within about $2 \% \Delta k / k$ of the measured $k_{\text {eff }}$ using a simplified assembly model that represents the gadolinium poison in a symmetric 8-pin arrangement. When the calculations for the Cycle 8 criticals are performed using a simplified 9-pin arrangement, a configuration closer to that of the fresh Cycle 8 assemblies, the results are improved to within approximately $1 \%$ for both reactor statepoints. These results suggest that the BWR CRCs can be predicted reasonably accurately without detailed information of the actual gadolinium pin distribution within the assemblies. More detailed calculations using the actual gadolinium pin distributions were not possible since the pin distributions for the assemblies in the LS1 CRCs were not available to ORNL for this work.

An homogenized representation of the gadolinium poison in the assembly generally results in a substantial underprediction in the $k_{\text {eff. }}$. Uniformly distributing the gadolinium in all fuel pins gives the poison excessive weight in the calculations, due to the intermixing of poison in all fissile material regions and due to shelf-shielding effects. Only the SP9 configuration was well predicted with the homogeneous representation since the gadolinium poison is essentially depleted at the Cycle 7 burnup of about $8000 \mathrm{MWd} / \mathrm{MTU}$, reducing the degree of heterogeneity in the assembly pin compositions.

Additional analyses are recommended to ensure that the approximations applied in these calculations have not significantly biased the results or produced offsetting biases. The sensitivity of the results to the average number of poison pins per assembly and the arrangement of the pins in the assemblies should be evaluated against a more detailed model that provides a closer representation of the actual assemblies (if this information is made available). It is also recommended that a sensitivity study of the key reactor state input parameters (e.g., moderator temperature and uniformity) be performed to determine the magnitude of state uncertainties on the results. 



\section{REFERENCES}

1. CRWMS/M\&O, Summary Report of Commercial Reactor Criticality Data for LaSalle Unit 1, Draft Report B-01717-5705-00138, Rev. B, Daft Report, prepared by for the U.S. Department of Energy, Yucca Mountain Site Characterization Project Office, July 1999.

2. $\quad$ L. M. Petrie and N. F. Landers, “KENO V.a: An Improved Monte Carlo Criticality Program with Supergrouping," Vol. 2, Sect. F11 of SCALE: A Modular Code System for Performing Standardized Computer Analyses for Licensing Evaluation, NUREG/CR0200, Rev. 5 (ORNL/NUREG/CSD-2/R5), Vols. I, II, and III, March 1997.

3. SCALE: A Modular Code System for Performing Standardized Computer Analyses for Licensing Evaluation, NUREG/CR-0200, Rev. 5 (ORNL/NUREG/CSD-2/R5), Vols. I, II, and III, March 1997.

4. General Electric Company, Core Design and Operating Data for Cycles 1 and 2 of Quad Cities 1, EPRI NP-240, Topical Report, November 1976.

5. W. C. Jordan and S. M. Bowman, "SCALE Cross-Section Libraries," Vol. 3, Sect. M4 of SCALE: A Modular Code System for Performing Standardized Computer Analyses for Licensing Evaluation, NUREG/CR-0200, Rev. 5 (ORNL/NUREG/CSD-2/R5), Vols. I, II, and III, March 1997.

David Henderson, Waste Package Design, Framatome Cogema Fuel Company, Las Vegas, Nevada, personal communication, 1999.

7. O. W. Hermann and C. V. Parks, "SAS2H: A Coupled One-Dimensional Depletion Analysis and Shielding Analysis Module," Vol. 1, Sect. S2 of SCALE: A Modular Code System for Performing Standardized Computer Analyses for Licensing Evaluation, NUREG/CR-0200, Rev. 5 (ORNL/NUREG/CSD-2/R5), Vols. I, II, and III, March 1997.

8. O. W. Hermann and R. M. Westfall, "ORIGEN-S: SCALE System Module to Calculate Fuel Depletion, Actinide Transmutation, Fission Product Buildup and Decay, and Associated Radiation Source Terms," Vol. 2, Sect. F7 of SCALE: A Modular Code System for Performing Standardized Computer Analyses for Licensing Evaluation, NUREG/CR-0200, Rev. 5 (ORNL/NUREG/CSD-2/R5), Vols. I, II, and III, March 1997.

9. N. F. Landers and L. M. Petrie, "CSAS: Control Module for Enhanced Criticality Safety Analysis Sequences," Vol. 1, Sect. C4 of SCALE: A Modular Code System for Performing Standardized Computer Analyses for Licensing Evaluation, NUREG/CR0200, Rev. 5 (ORNL/NUREG/CSD-2/R5), Vols. I, II, and III, March 1997. 



\section{APPENDIX A}

CSASI INPUT LISTING FOR ASSEMBLY C14, ZONE 4, SP11 



\section{Appendix A}

\section{CSASI Input Listing for Assembly C14, Zone 4, SP11}

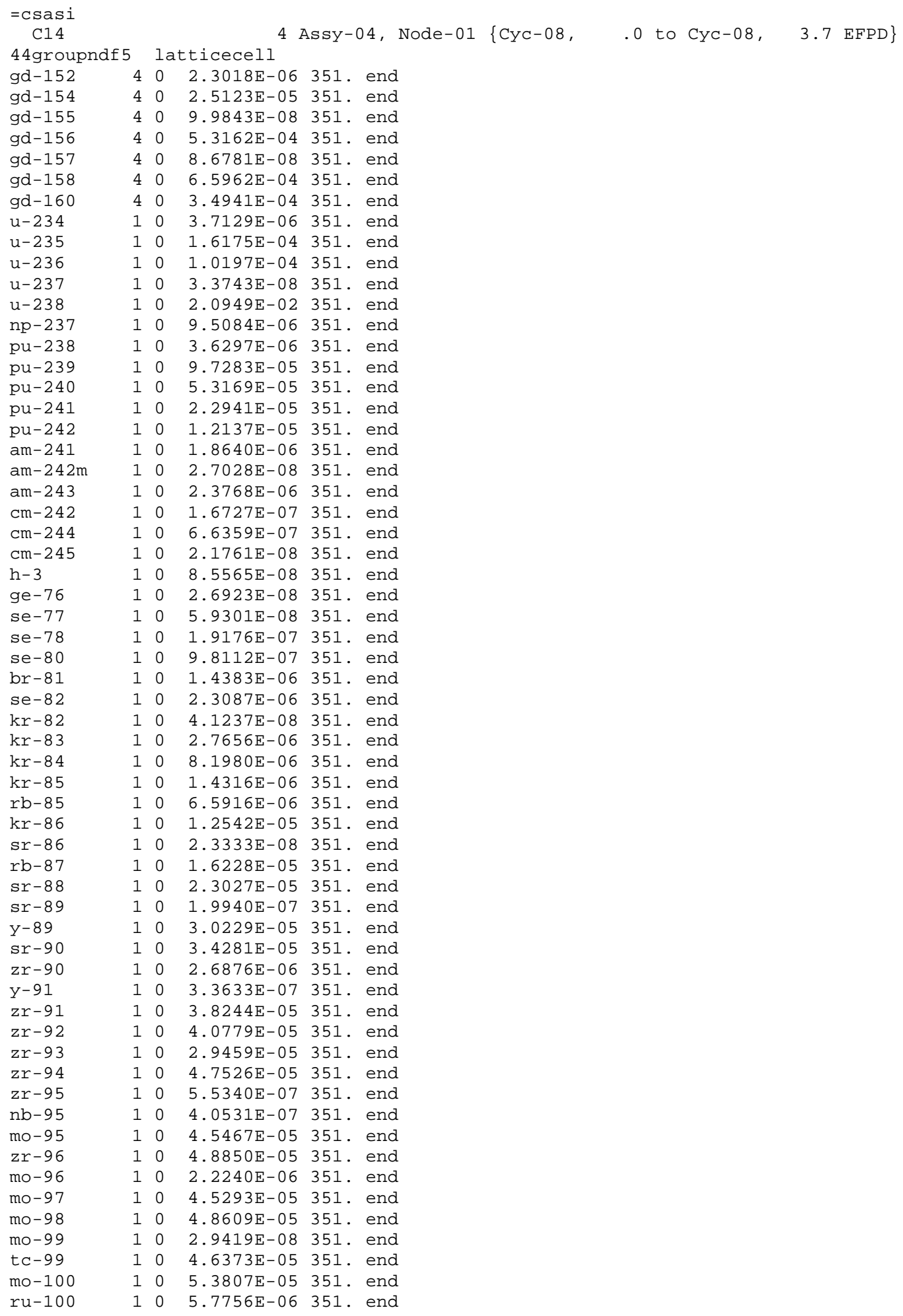




\begin{tabular}{|c|c|c|c|c|c|}
\hline$r u-101$ & 1 & 0 & 4. $4232 \mathrm{E}-05$ & 351 . & end \\
\hline$r u-102$ & 1 & 0 & $4.3557 \mathrm{E}-05$ & 351 . & end \\
\hline$r u-103$ & 1 & 0 & $2.5880 \mathrm{E}-07$ & 351 . & end \\
\hline$r h-103$ & 1 & 0 & $2.5401 \mathrm{E}-05$ & 351 . & end \\
\hline$r u-104$ & 1 & 0 & $2.9429 E-05$ & 351 . & end \\
\hline$p d-104$ & 1 & 0 & 1. $2294 \mathrm{E}-05$ & 351 . & end \\
\hline$p d-105$ & 1 & 0 & $2.0545 E-05$ & 351 . & end \\
\hline$r u-106$ & 1 & 0 & $4.0982 \mathrm{E}-06$ & 351 . & end \\
\hline$p d-106$ & 1 & 0 & 1. $4553 \mathrm{E}-05$ & 351. & end \\
\hline$p d-107$ & 1 & 0 & $1.1418 \mathrm{E}-05$ & 351 . & end \\
\hline$p d-108$ & 1 & 0 & $7.4504 \mathrm{E}-06$ & 351. & end \\
\hline ag-109 & 1 & 0 & $4.5288 \mathrm{E}-06$ & & end \\
\hline$p d-110$ & 1 & 0 & $2.1832 \mathrm{E}-06$ & 351 . & end \\
\hline$c d-110$ & 1 & 0 & $1.8018 \mathrm{E}-06$ & & end \\
\hline$c d-111$ & 1 & 0 & $1.1074 \mathrm{E}-06$ & 351. & end \\
\hline$c d-112$ & 1 & 0 & $5.7739 \mathrm{E}-07$ & & end \\
\hline$c d-114$ & 1 & 0 & $5.8891 \mathrm{E}-07$ & 351. & end \\
\hline in-115 & 1 & 0 & $7.4261 \mathrm{E}-08$ & & end \\
\hline$c d-116$ & 1 & 0 & $2.4044 \mathrm{E}-07$ & & end \\
\hline$s n-116$ & 1 & 0 & $1.0596 \mathrm{E}-07$ & 351. & end \\
\hline$s n-117$ & 1 & 0 & $2.2151 E-07$ & 351. & end \\
\hline$s n-118$ & 1 & 0 & $1.7759 \mathrm{E}-07$ & 351. & \\
\hline$s n-119$ & 1 & 0 & $1.8418 \mathrm{E}-07$ & 351. & end \\
\hline $\mathrm{sn}-120$ & 1 & 0 & $1.8018 \mathrm{E}-07$ & 351 . & end \\
\hline$s b-121$ & 1 & 0 & $1.7808 \mathrm{E}-07$ & 351. & end \\
\hline$s n-122$ & 1 & 0 & $2.3064 \mathrm{E}-07$ & 351 . & end \\
\hline te-122 & 1 & 0 & $1.0965 \mathrm{E}-08$ & 351. & end \\
\hline$s b-123$ & 1 & 0 & $2.0669 E-07$ & 351 . & end \\
\hline $\mathrm{sn}-124$ & 1 & 0 & $3.8018 \mathrm{E}-07$ & 351. & end \\
\hline$s b-125$ & 1 & 0 & $2.4485 E-07$ & 351 . & end \\
\hline te-125 & 1 & 0 & $1.9746 \mathrm{E}-07$ & 351. & end \\
\hline$s n-126$ & 1 & 0 & $8.5800 \mathrm{E}-07$ & 351 . & end \\
\hline te-126 & 1 & 0 & $1.5103 E-08$ & 351. & end \\
\hline te-127m & 1 & 0 & $1.2963 \mathrm{E}-08$ & 351 . & end \\
\hline$i-127$ & 1 & 0 & $1.8755 \mathrm{E}-06$ & 351. & end \\
\hline$t e-128$ & 1 & 0 & $4.0108 E-06$ & 351. & end \\
\hline$x e-128$ & 1 & 0 & $1.0278 \mathrm{E}-07$ & 351 . & end \\
\hline$i-129$ & 1 & 0 & $7.9404 \mathrm{E}-06$ & 351 . & end \\
\hline$t e-130$ & 1 & 0 & $1.6062 \mathrm{E}-05$ & 351. & end \\
\hline$x e-130$ & 1 & 0 & $3.5314 \mathrm{E}-07$ & 351 . & \\
\hline$i-131$ & 1 & 0 & $4.9741 \mathrm{E}-08$ & 351 . & end \\
\hline$x e-131$ & 1 & 0 & $1.8578 \mathrm{E}-05$ & 351 . & \\
\hline te-132 & 1 & 0 & $2.9544 \mathrm{E}-08$ & 351 . & en \\
\hline$x e-132$ & 1 & 0 & $4.7494 \mathrm{E}-05$ & 351. & \\
\hline$x e-133$ & 1 & 0 & $8.5924 \mathrm{E}-08$ & 351. & end \\
\hline$c s-133$ & 1 & 0 & $5.0292 \mathrm{E}-05$ & 351 . & \\
\hline$x e-134$ & 1 & 0 & $6.4837 \mathrm{E}-05$ & 351. & \\
\hline$c s-134$ & 1 & 0 & $3.3155 E-06$ & 351. & \\
\hline$b a-134$ & 1 & 0 & $3.1682 \mathrm{E}-06$ & 351. & end \\
\hline$c s-135$ & 1 & 0 & $1.5614 \mathrm{E}-05$ & 351 . & \\
\hline$b a-135$ & 1 & 0 & $1.5541 \mathrm{E}-08$ & 351. & end \\
\hline$x e-136$ & 1 & 0 & $9.6732 \mathrm{E}-05$ & 351. & \\
\hline$b a-136$ & 1 & 0 & $6.9509 \mathrm{E}-07$ & 351. & \\
\hline$c s-137$ & 1 & 0 & $5.0625 E-05$ & 351. & \\
\hline$b a-137$ & 1 & 0 & $3.4231 E-06$ & 351. & end \\
\hline$b a-138$ & 1 & 0 & $5.3836 \mathrm{E}-05$ & 351. & \\
\hline $1 a-139$ & 1 & 0 & $5.0252 E-05$ & 351. & end \\
\hline $\mathrm{ba}-140$ & 1 & 0 & $1.0754 \mathrm{E}-07$ & 351 . & end \\
\hline $1 a-140$ & 1 & 0 & $1.5144 \mathrm{E}-08$ & 351 . & \\
\hline$c e-140$ & 1 & 0 & $5.1127 \mathrm{E}-05$ & 351. & \\
\hline$c e-141$ & 1 & 0 & $1.9956 \mathrm{E}-07$ & 351. & end \\
\hline pr-141 & 1 & 0 & $4.5163 E-05$ & 351. & \\
\hline$c e-142$ & 1 & 0 & $4.5888 \mathrm{E}-05$ & 351. & end \\
\hline$n d-142$ & 1 & 0 & $8.7430 \mathrm{E}-07$ & 351. & \\
\hline$p r-143$ & 1 & 0 & $9.8729 \mathrm{E}-08$ & 351 . & end \\
\hline$n d-143$ & 1 & 0 & $3.0896 \mathrm{E}-05$ & 351. & \\
\hline$c e-144$ & 1 & 0 & $5.3135 E-06$ & 351. & end \\
\hline$n d-144$ & 1 & 0 & $4.9021 E-05$ & 351. & \\
\hline$n d-145$ & 1 & 0 & $2.6895 \mathrm{E}-05$ & 351 . & end \\
\hline$n d-146$ & 1 & 0 & $2.7556 \mathrm{E}-05$ & 351. & \\
\hline$n d-147$ & 1 & 0 & $3.7611 \mathrm{E}-08$ & 351 . & end \\
\hline $\mathrm{pm}-147$ & 1 & 0 & $5.2387 \mathrm{E}-06$ & 351. & \\
\hline
\end{tabular}




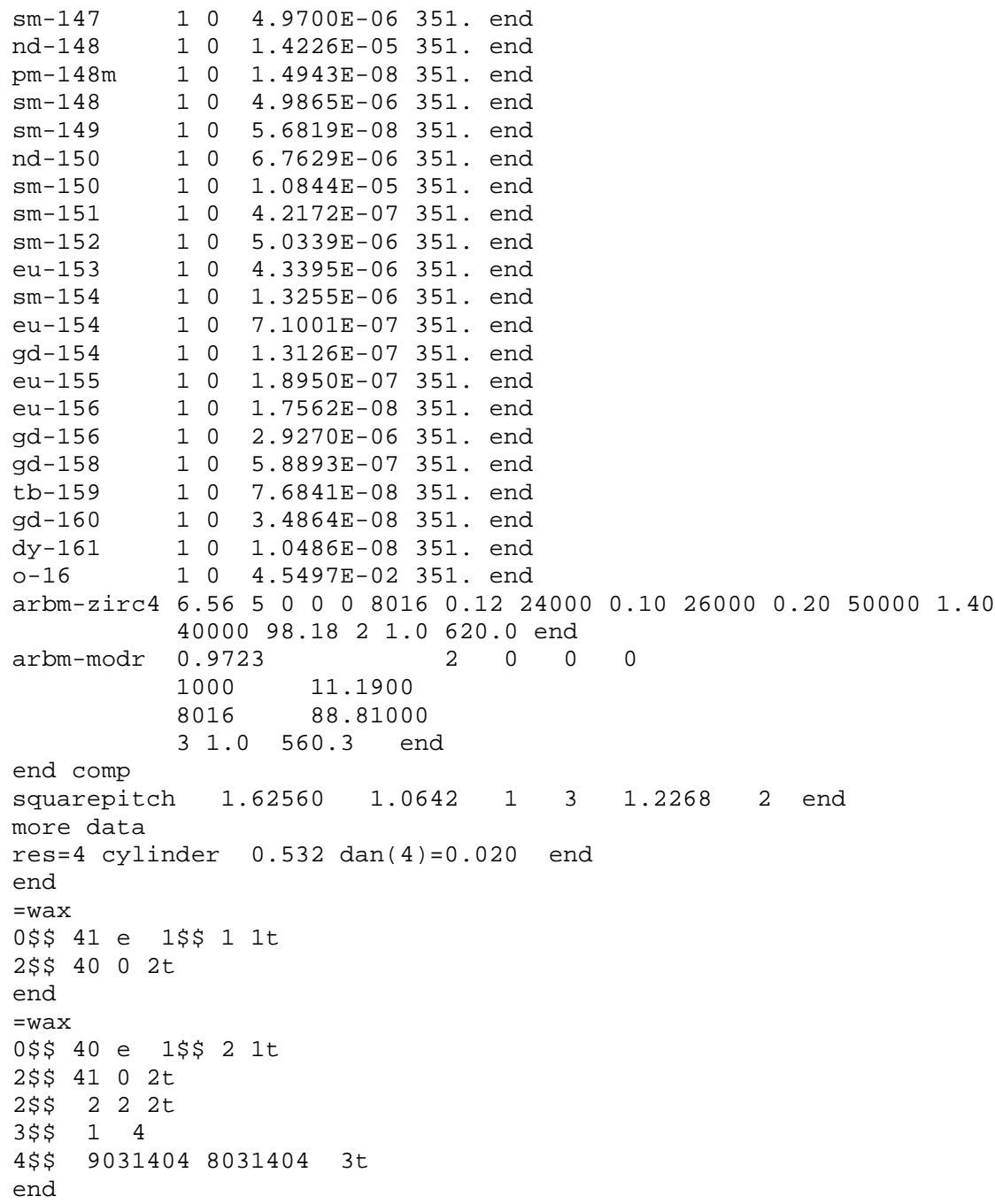



APPENDIX B

GECKO FORTRAN UTILITY CODE LISTING 



\section{Appendix B}

\section{GECKO Fortran Utility Code Listing}

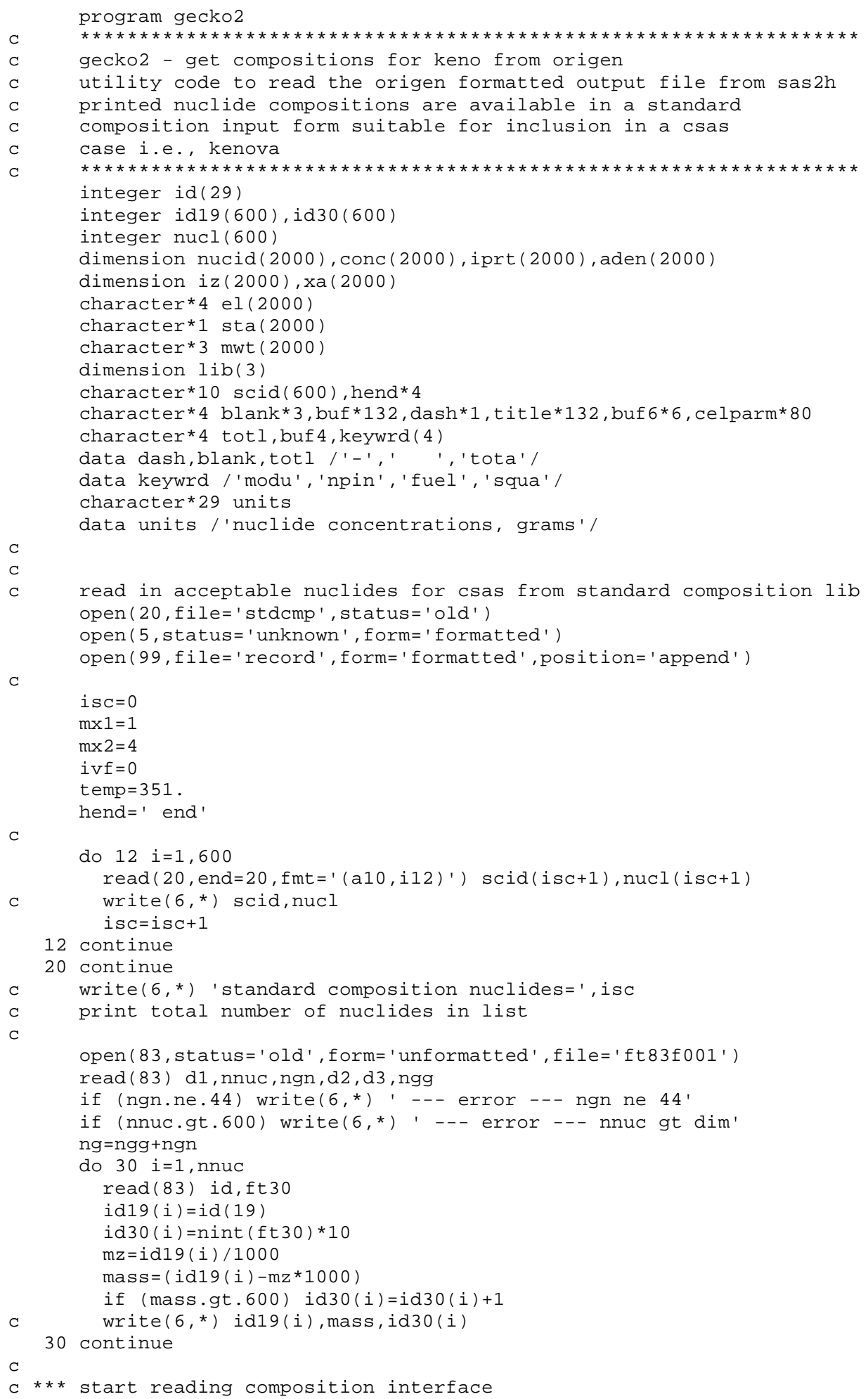




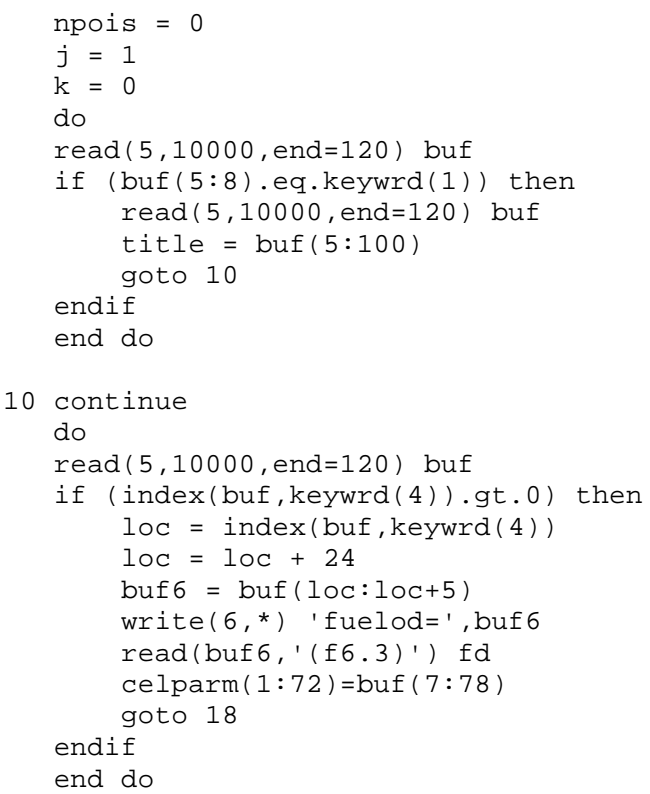




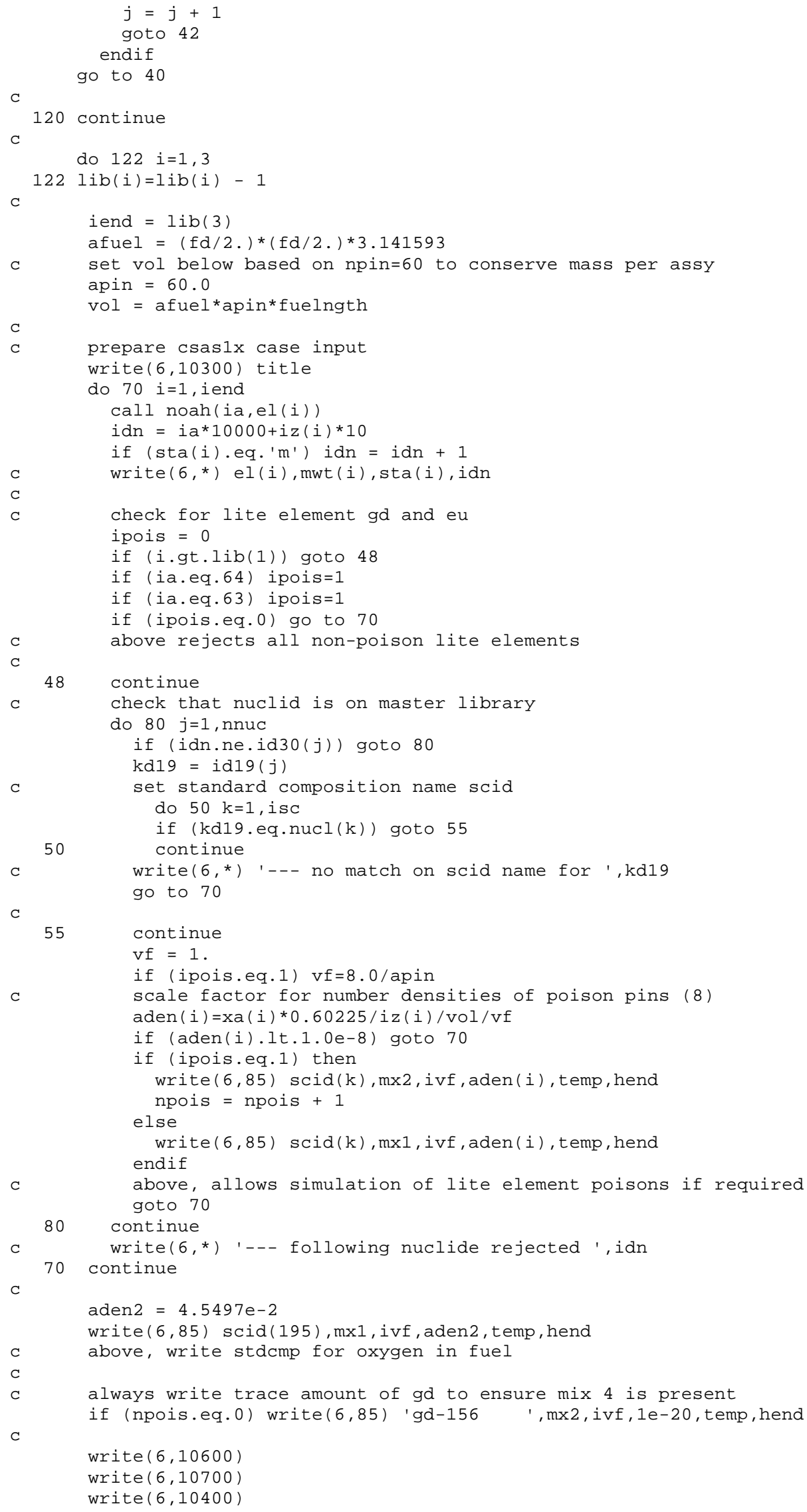




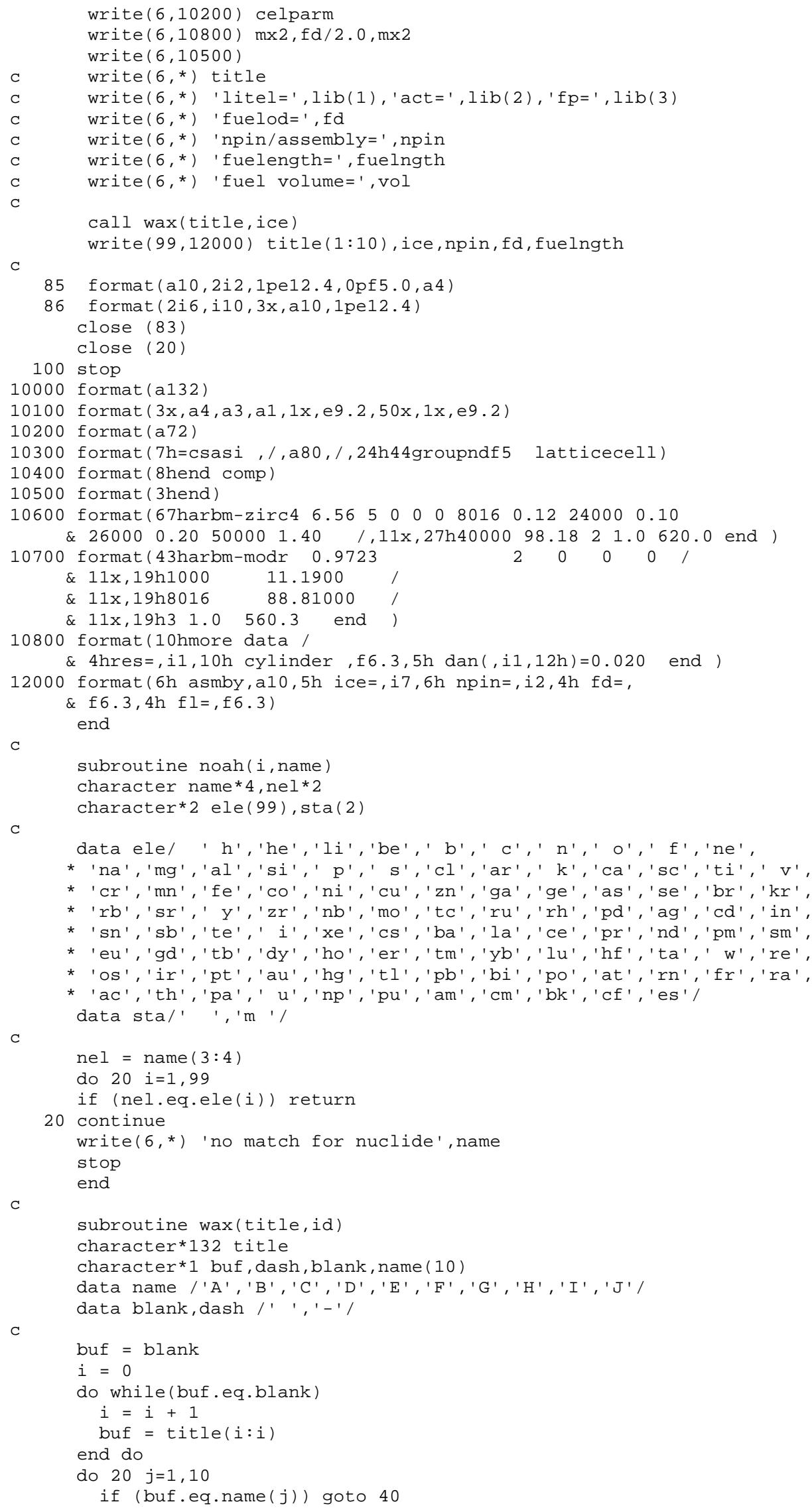


20 continue

write $\left(6,{ }^{*}\right)$ ' --- error --- invalid name ', buf stop

40 id $=j * 10000$

$i=i+1$

read(title(i:i), '(i1)') n1

$i=i+1$

buf = title(i:i)

if (buf.eq.dash) then

nas $=n 1$

else if (buf.eq.blank) then

nas $=n 1$

else

read (buf, '(i1)') n2

nas $=n 1 * 10+n 2$

endif

$i=i+10$

buf = blank

do while (buf.eq.blank)

$i=i+1$

buf = title(i:i)

end do

read(title(i:i+1),'(i2)') node

$i d=i d+$ nas* $100+$ node

$i d 1=i d+9000000$

C

$i d 2=i d+8000000$

write $(6, '(4 h=$ wax $) ')$

write $(6, '(20 h 0 \$ \$ 4$ e $1 \$ \$ 1$ t ) ')

write $\left(6, '\left(20 \mathrm{~h} 2 \$ \$ 400 \mathrm{t} \quad \mathrm{t}^{\prime}\right)\right.$ ')

write $(6, '$ (3hend) ')

write $(6, '(4 \mathrm{~h}=$ wax $)$ ')

write $(6, '(20 h 0 \$ \$ 40$ e $1 \$ \$ 2$ 1t )')

write $(6, '(20 \mathrm{~h} 2 \$ \$ 410 \mathrm{t} \quad)$ ')

write $\left(6, '\left(20 \mathrm{~h} 2 \$ \$ 22 \mathrm{t} \quad{ }^{2}\right)\right.$

write $(6, '(10 \mathrm{~h} 3 \$ \$ 1 \quad 4)$ ')

write $(6, '(4 \mathrm{~h} 4 \$ \$, 2(i 8), 4 \mathrm{~h} 3 t) ')$ id1, id2

write (6,' (3hend)')

return

end 

APPENDIX C

LS1K FORTRAN UTILITY CODE LISTING

AND ASSEMBLY MAP 



\section{Appendix C}

\section{LS1K Fortran Utility Code Listing and Assembly Map}

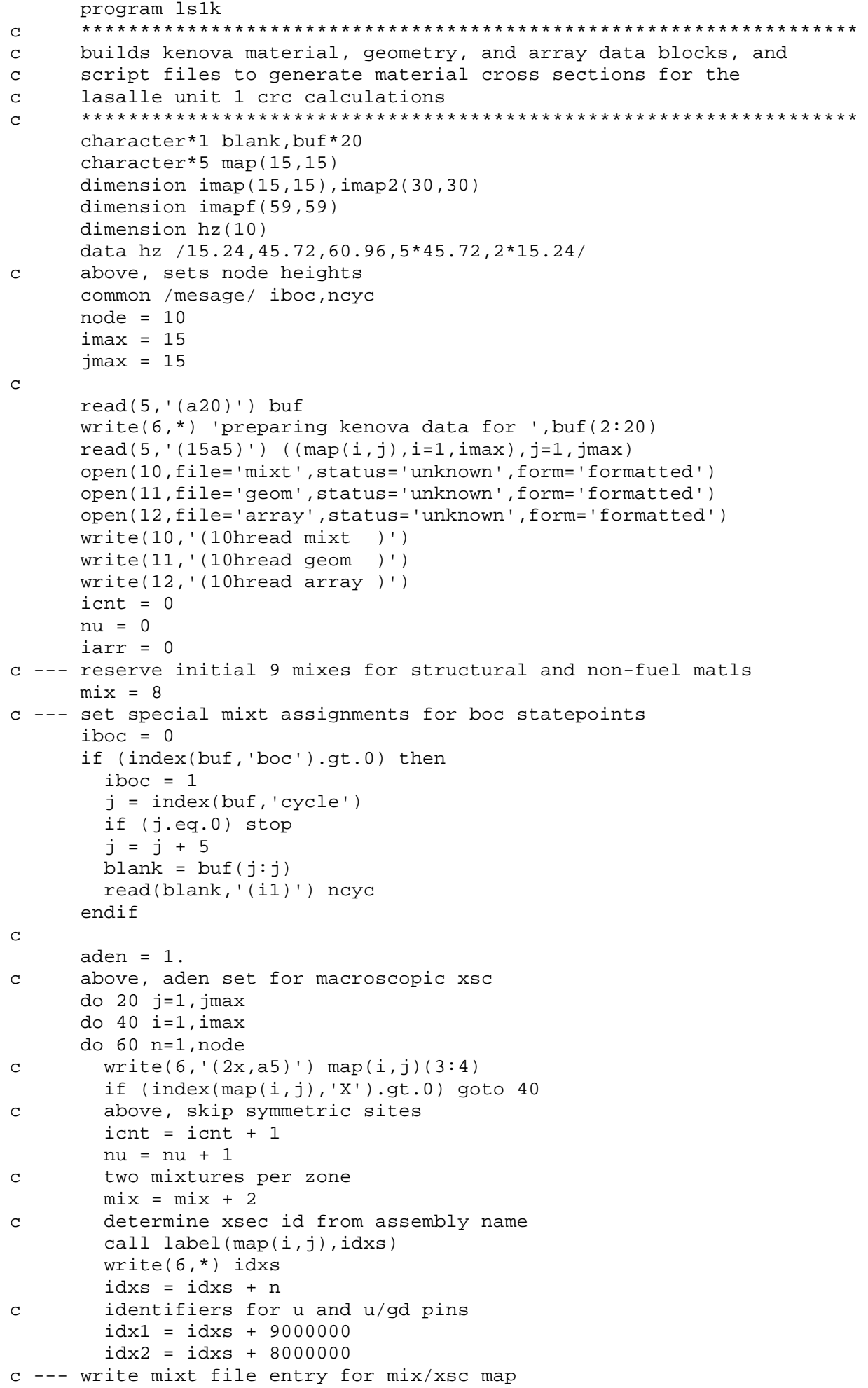




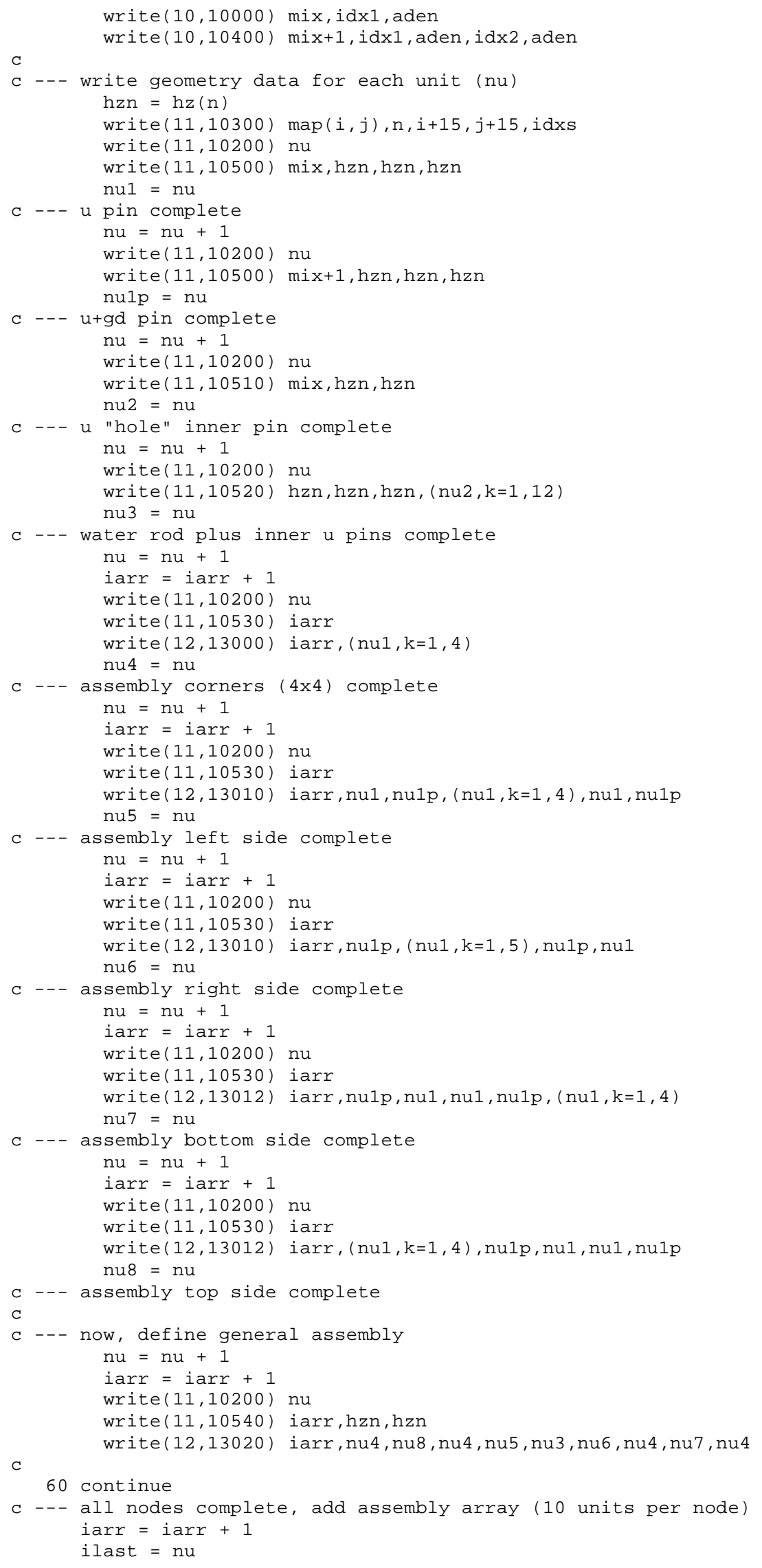




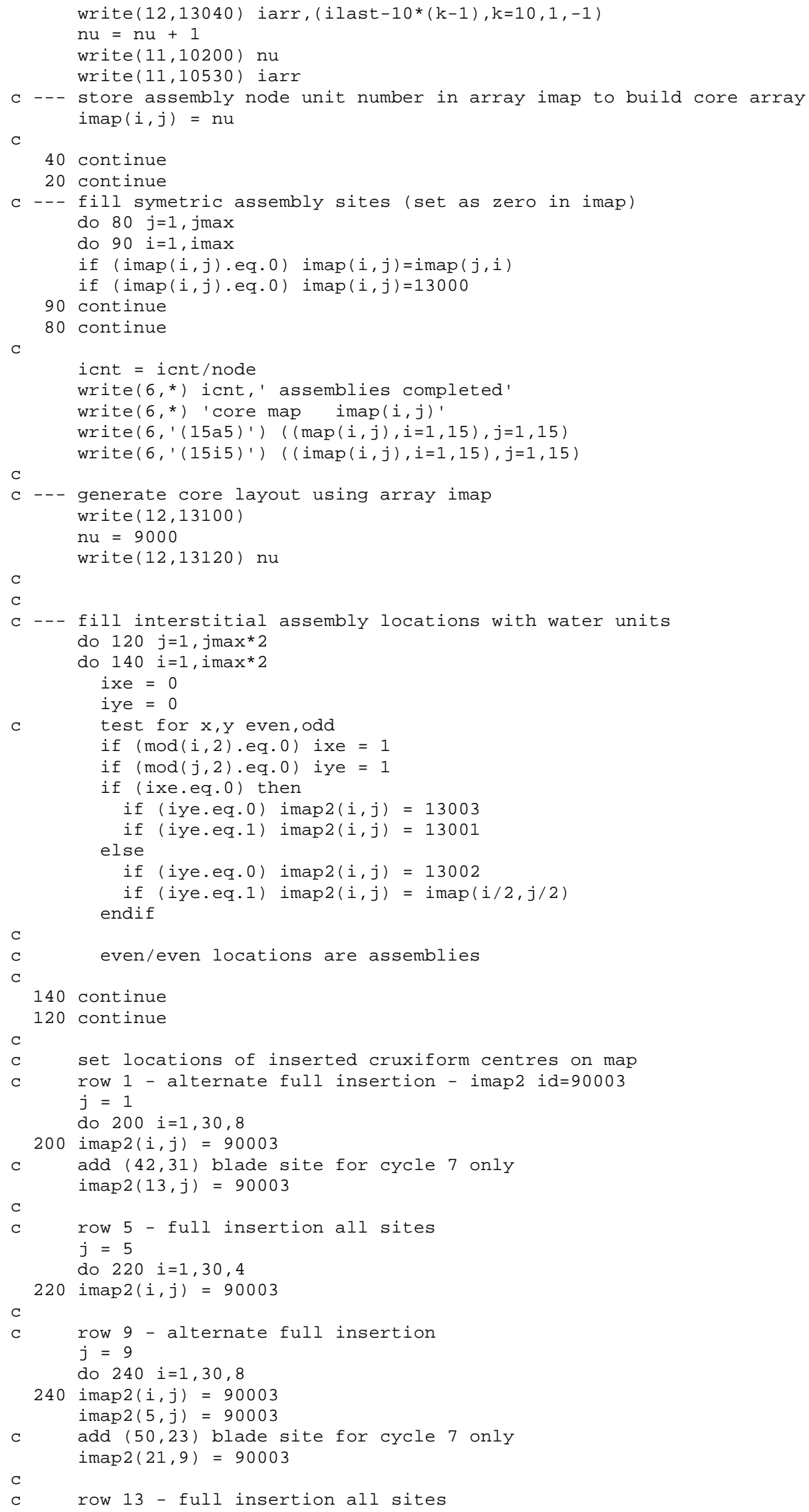




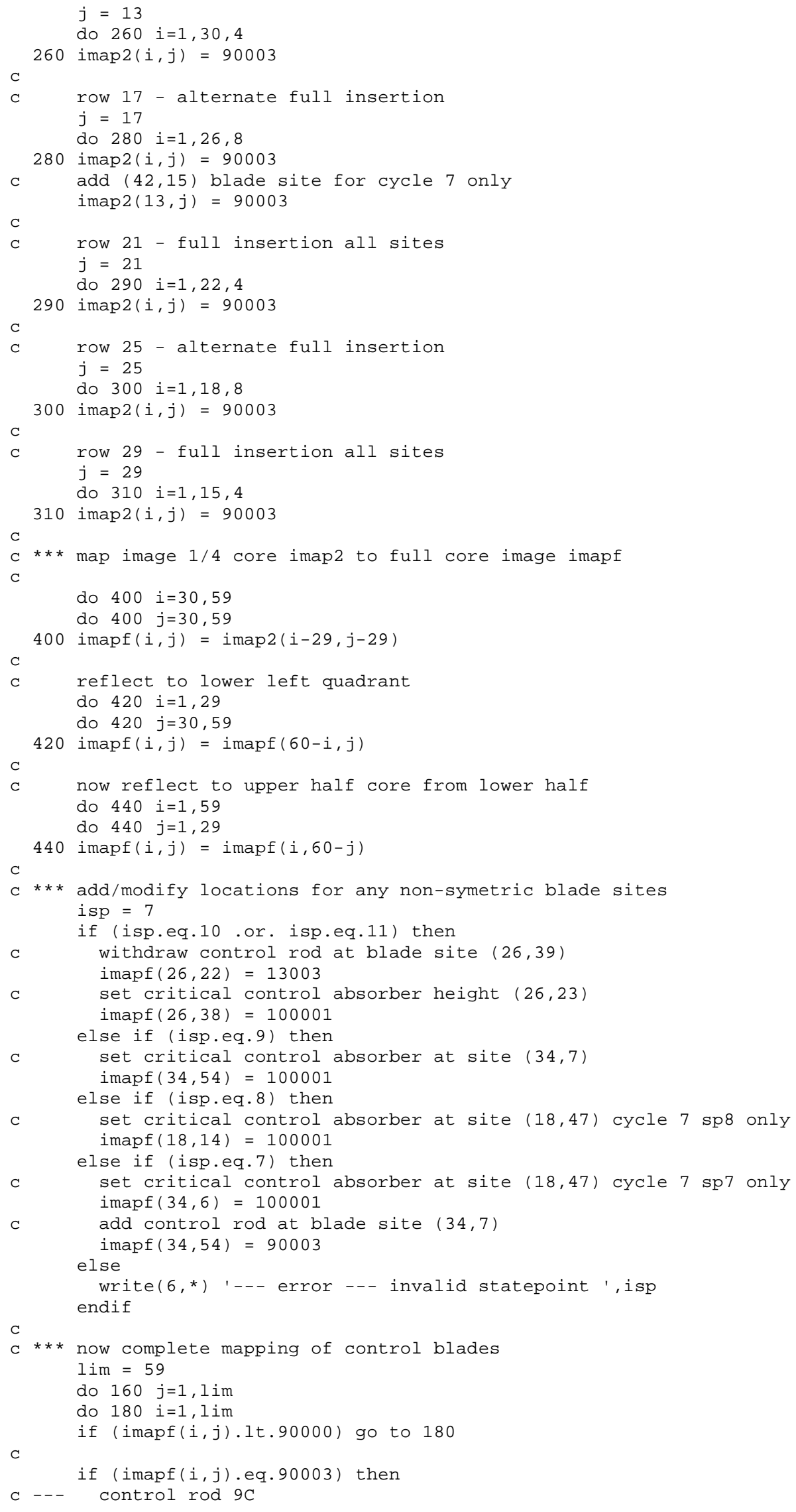




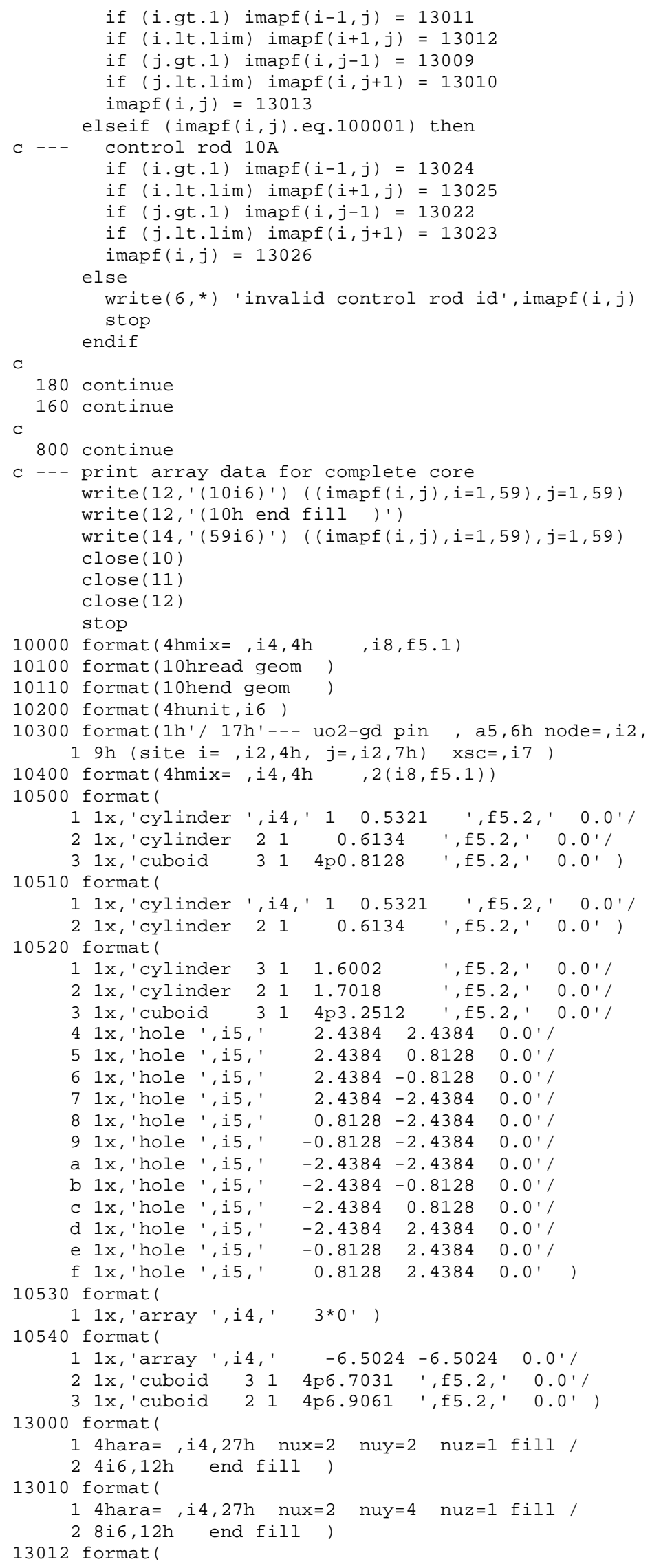




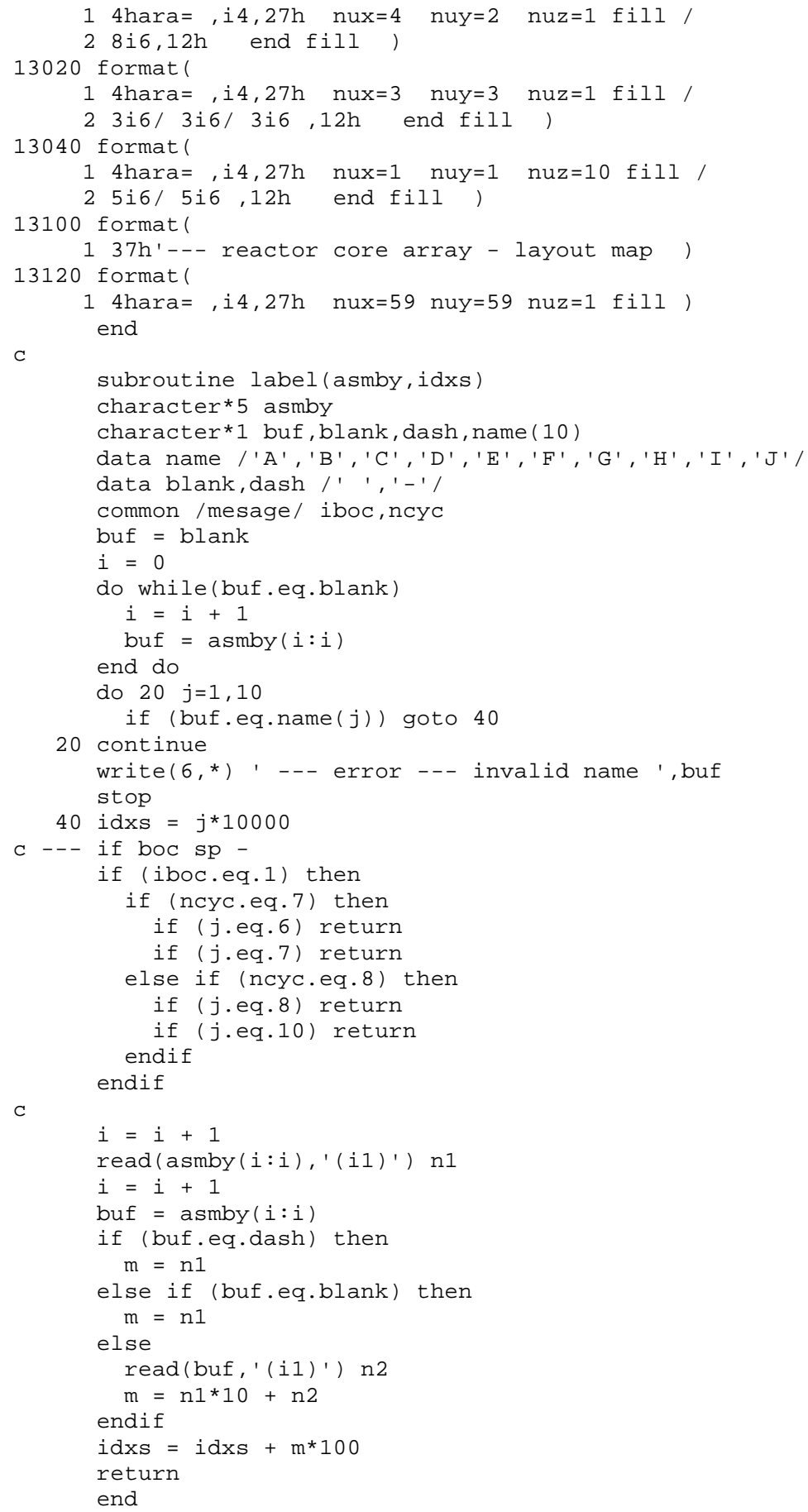




\section{Cycle 8 Assembly Map}

\begin{tabular}{|c|c|c|c|c|c|c|c|c|c|c|c|c|c|c|}
\hline \multicolumn{15}{|c|}{ cycles } \\
\hline D 4 & H18 & F3 & D13 & E6 & J5 & F17 & E9 & D15 & J11 & $\mathrm{F} 6$ & F2 & D10 & E5 & C4 \\
\hline $\mathrm{X}$ & D16 & J6 & G7 & $\mathrm{J} 12$ & F7 & J4 & F1 & H10 & E7 & J10 & H 6 & H7 & E1 & C5 \\
\hline F 10 & $x$ & F 4 & H9 & G12 & J8 & F14 & J9 & G14 & H1 6 & F16 & H12 & F15 & D7 & $\mathrm{C} 2$ \\
\hline $\mathrm{x}$ & G11 & $\mathrm{X}$ & D12 & D2 & G15 & J2 & D3 & E2 & G5 & H1 5 & G9 & D19 & D21 & C19 \\
\hline $\mathrm{X}$ & $x$ & $\mathrm{x}$ & D14 & G1 & J13 & G6 & D11 & G3 & J7 & H1 & D20 & D 6 & D9 & C29 \\
\hline $\mathrm{X}$ & $\mathrm{x}$ & $\mathrm{x}$ & $x$ & $\mathrm{X}$ & G10 & H5 & G4 & J1 & H2 & C14 & H11 & F9 & E8 & C25 \\
\hline $\mathrm{x}$ & $\mathrm{x}$ & $\mathrm{x}$ & $\mathrm{x}$ & $\mathrm{x}$ & $x$ & D 8 & J3 & H13 & $\mathrm{G} 2$ & H17 & H3 & G1 6 & E3 & $\mathrm{C} 1$ \\
\hline $\mathrm{X}$ & $\mathrm{F} 18$ & $\mathrm{x}$ & D 5 & $\mathrm{X}$ & G8 & X & D18 & D17 & H8 & H1 4 & H4 & E12 & C26 & X \\
\hline $\mathrm{X}$ & $\mathrm{X}$ & $\mathrm{x}$ & E4 & $\mathrm{X}$ & $\mathrm{X}$ & $\mathrm{X}$ & $x$ & D1 & F11 & G13 & F5 & C3 & $x$ & $\mathrm{x}$ \\
\hline $\mathrm{x}$ & E11 & $\mathrm{x}$ & $\mathrm{x}$ & $\mathrm{x}$ & $\mathrm{x}$ & $\mathrm{x}$ & $\mathrm{x}$ & $\mathrm{x}$ & F13 & $\mathrm{C} 21$ & C27 & C22 & $\mathrm{x}$ & $\mathrm{x}$ \\
\hline $\mathrm{X}$ & $\mathrm{x}$ & $\mathrm{x}$ & $\mathrm{x}$ & $\mathrm{x}$ & $\mathrm{x}$ & $\mathrm{x}$ & $\mathrm{x}$ & $\mathrm{x}$ & $\mathrm{x}$ & C9 & $\mathrm{X}$ & $\mathrm{x}$ & $\mathrm{x}$ & $\mathrm{x}$ \\
\hline F12 & $\mathrm{x}$ & $\mathrm{x}$ & $\mathrm{x}$ & $\mathrm{x}$ & $\mathrm{x}$ & $\mathrm{x}$ & $\mathrm{x}$ & F 8 & $\mathrm{x}$ & $\mathrm{x}$ & $\mathrm{X}$ & $\mathrm{x}$ & $\mathrm{x}$ & $\mathrm{x}$ \\
\hline X & $\mathrm{x}$ & $\mathrm{x}$ & $\mathrm{x}$ & $\mathrm{x}$ & $\mathrm{x}$ & $\mathrm{x}$ & $\mathrm{X}$ & $\mathrm{C} 12$ & C28 & $\mathrm{x}$ & X & $\mathrm{X}$ & $\mathrm{x}$ & $\mathrm{x}$ \\
\hline E10 & $\mathrm{x}$ & $\mathrm{x}$ & $\mathrm{X}$ & $\mathrm{x}$ & $\mathrm{X}$ & $\mathrm{x}$ & $\mathrm{X}$ & $x$ & $x$ & $\mathrm{x}$ & $\mathrm{x}$ & $\mathrm{x}$ & $\mathrm{x}$ & $\mathrm{x}$ \\
\hline C8 & $\mathrm{x}$ & $\mathrm{x}$ & C17 & $\mathrm{x}$ & $\mathrm{X}$ & $\mathrm{X}$ & $\mathrm{x}$ & $\mathrm{x}$ & $\mathrm{X}$ & $\mathrm{x}$ & $\mathrm{x}$ & $\mathrm{X}$ & $\mathrm{X}$ & $\mathrm{x}$ \\
\hline
\end{tabular}





\section{APPENDIX D ABRIDGED KENO V.A INPUT LISTING FOR LS1 STATEPOINT CONFIGURATIONS}





\section{Appendix D}

\section{Abbreviated KENO V.a Input Listing for LS1 Statepoint Configurations}

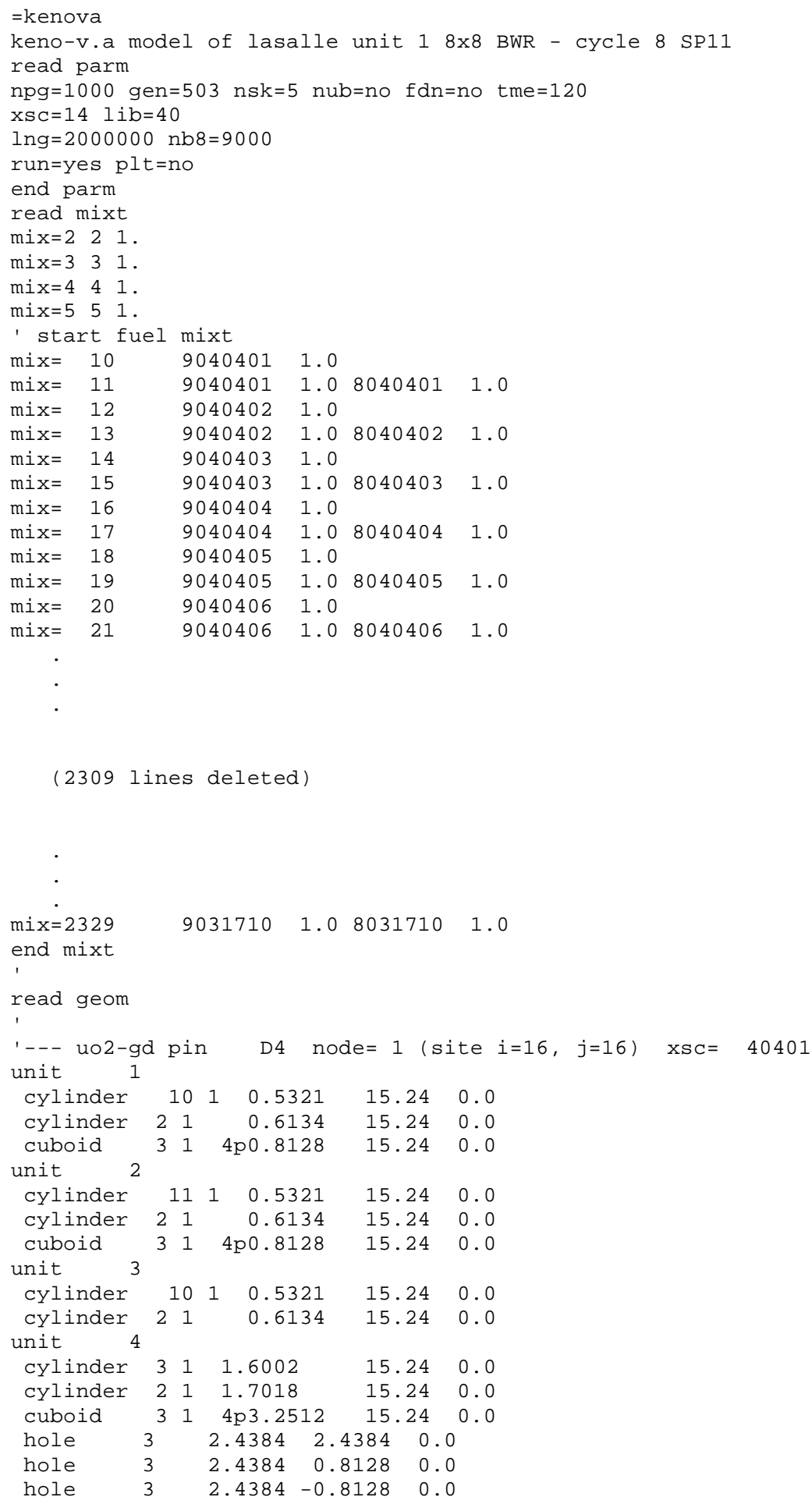




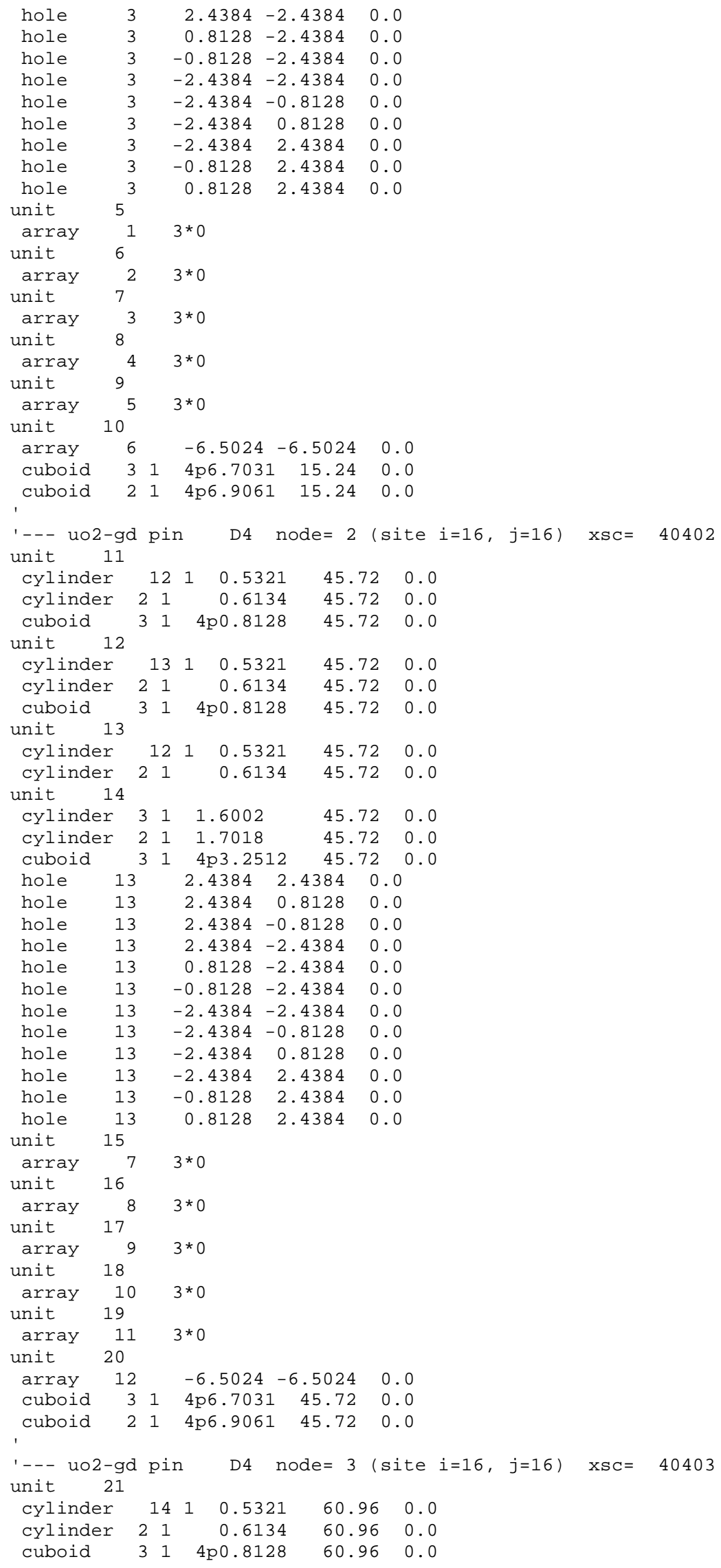




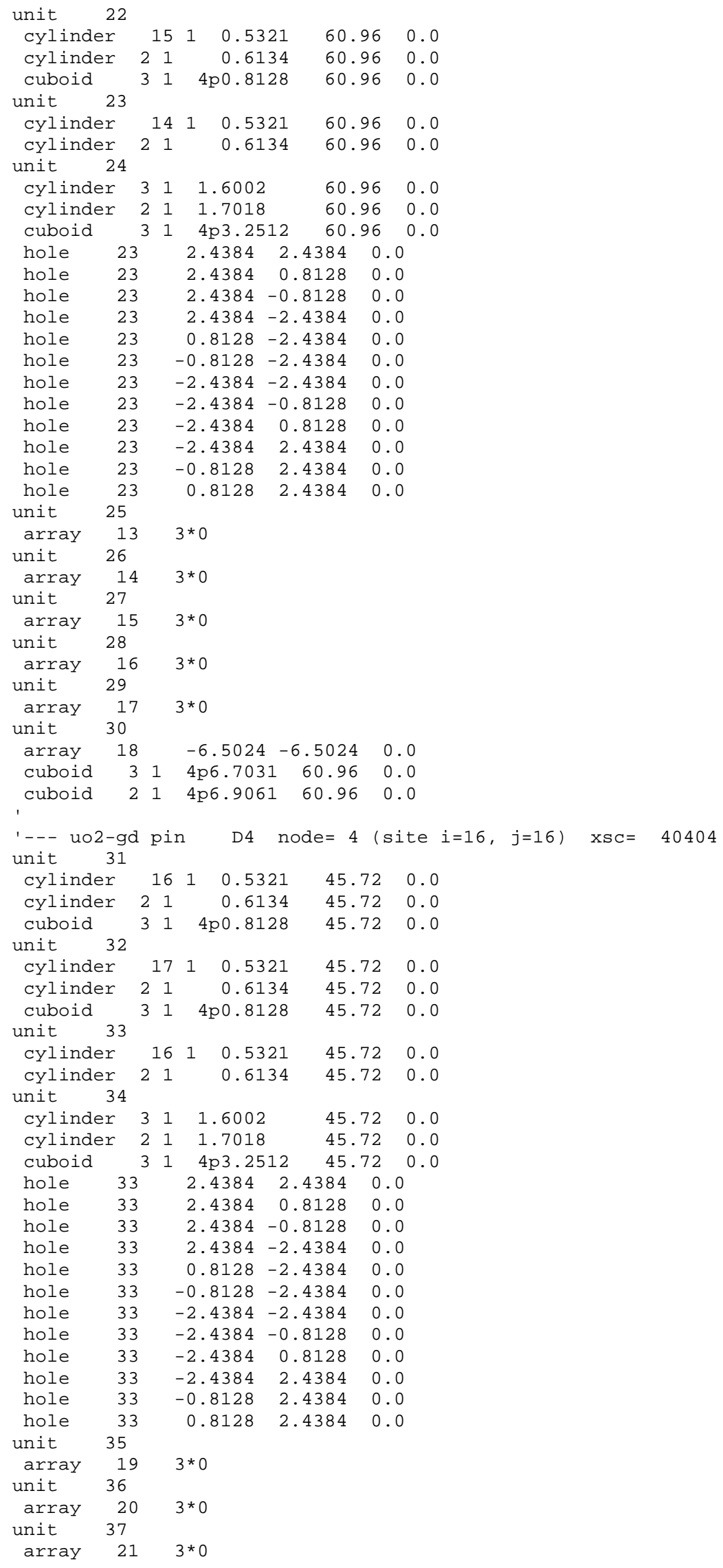




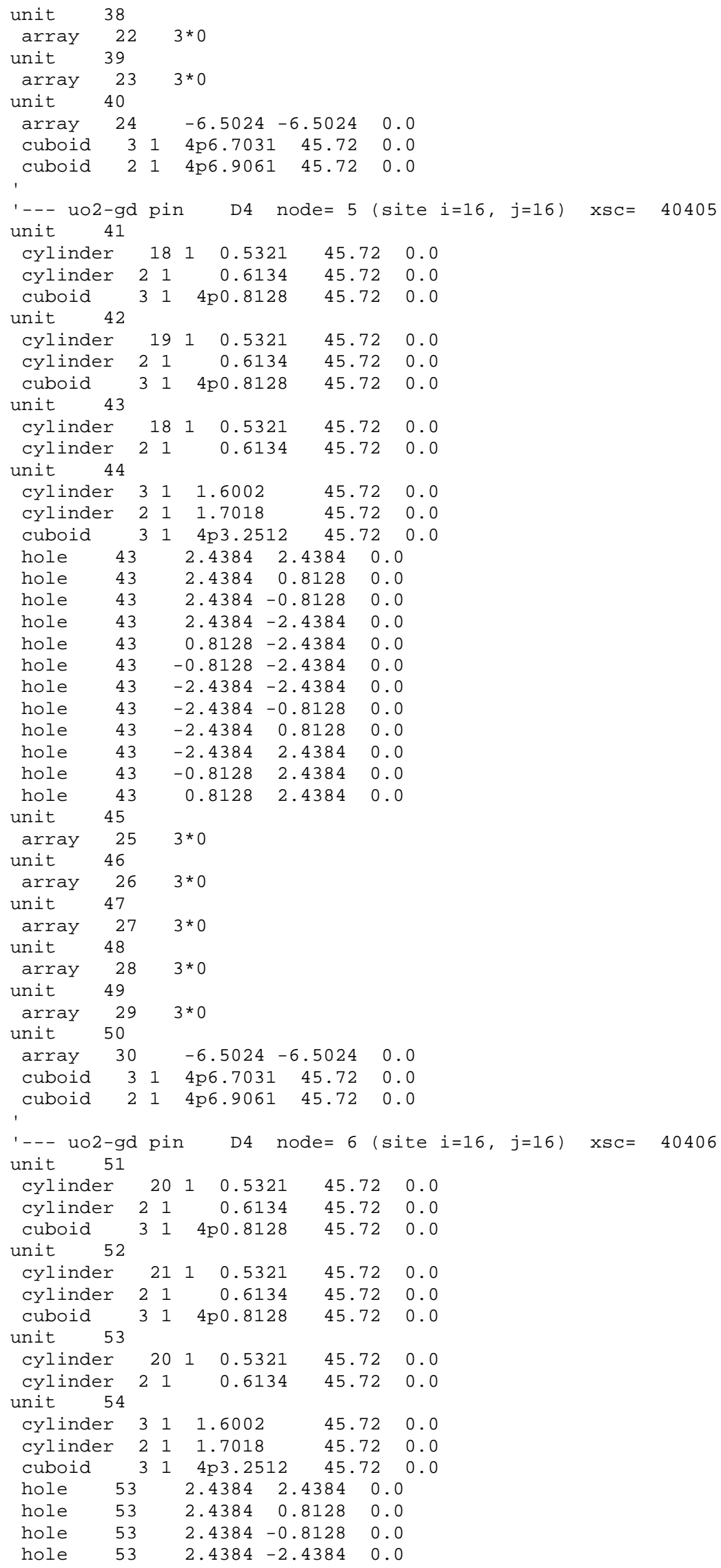




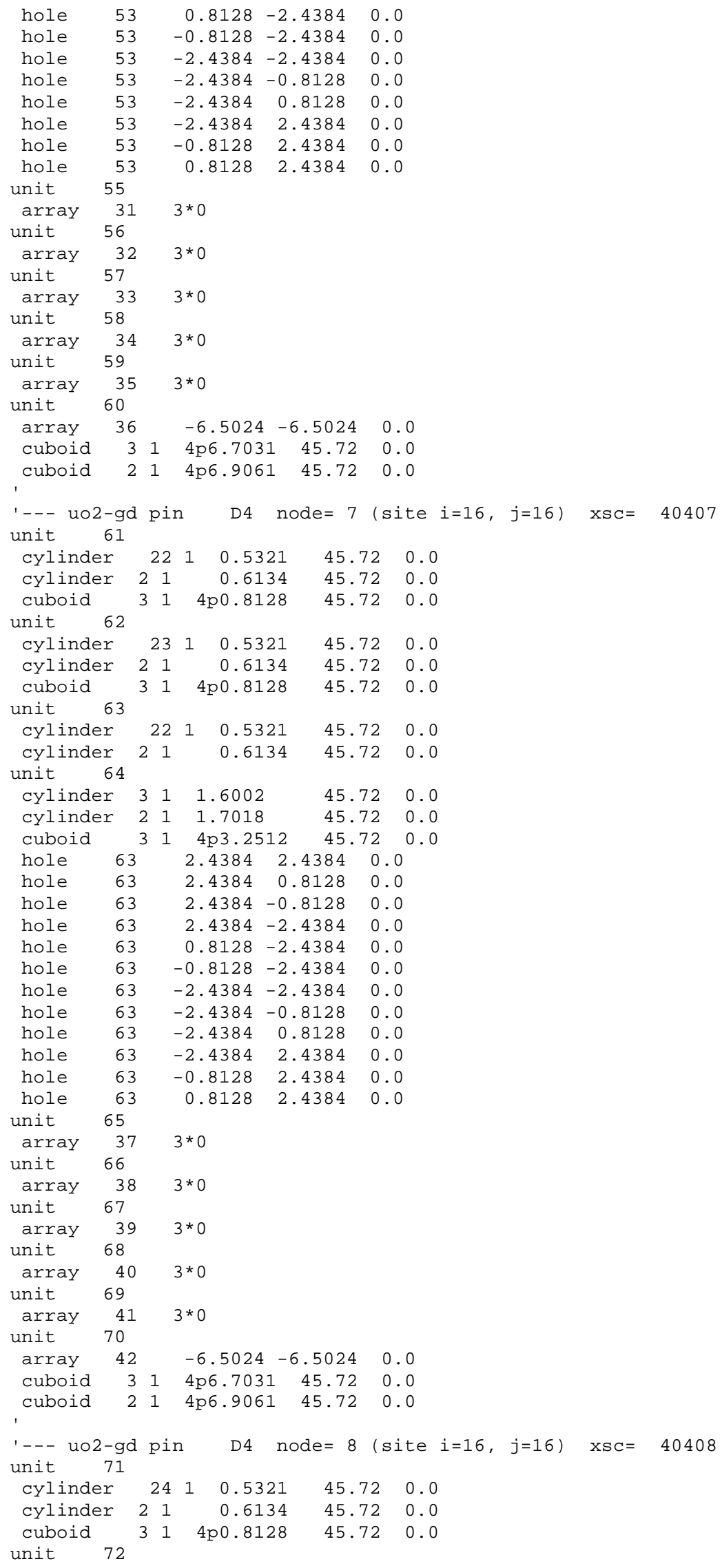




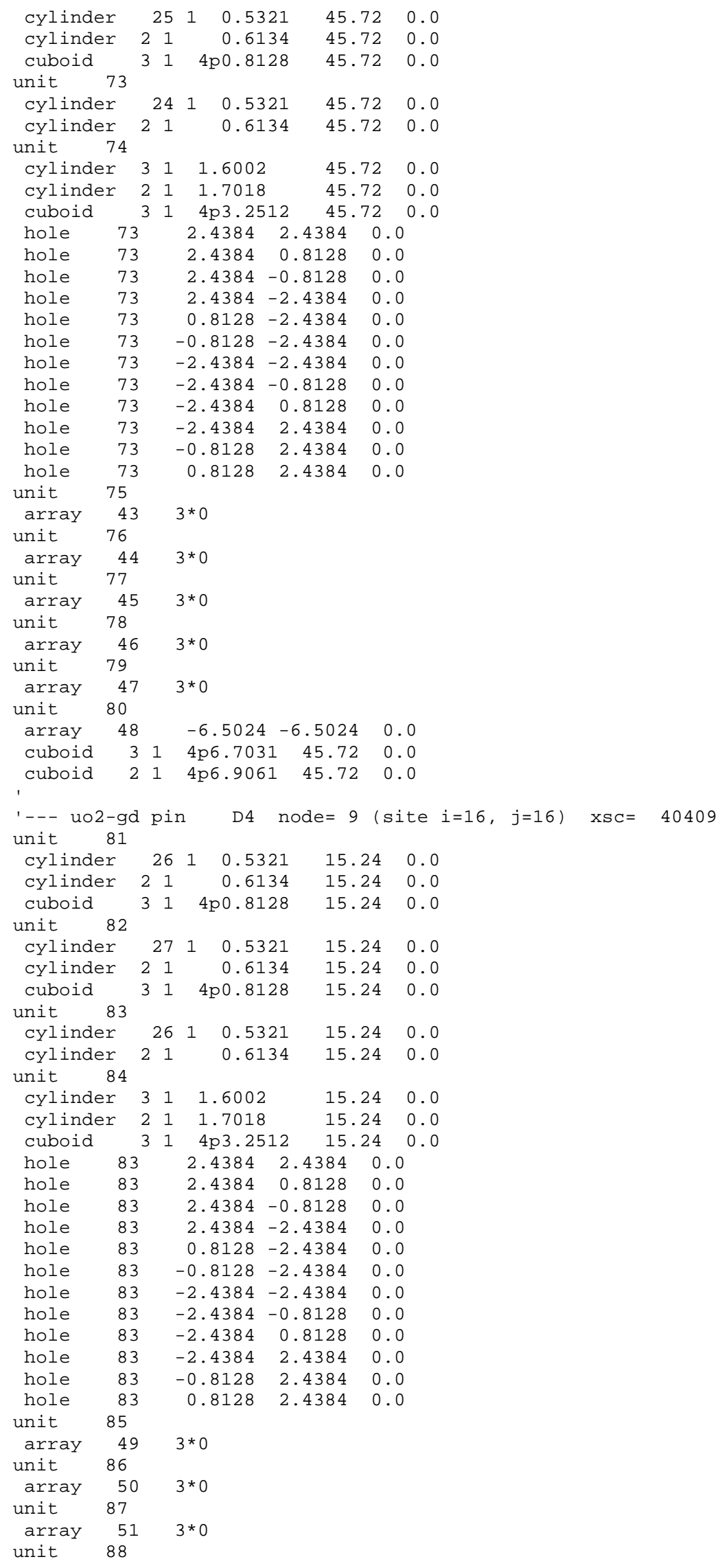




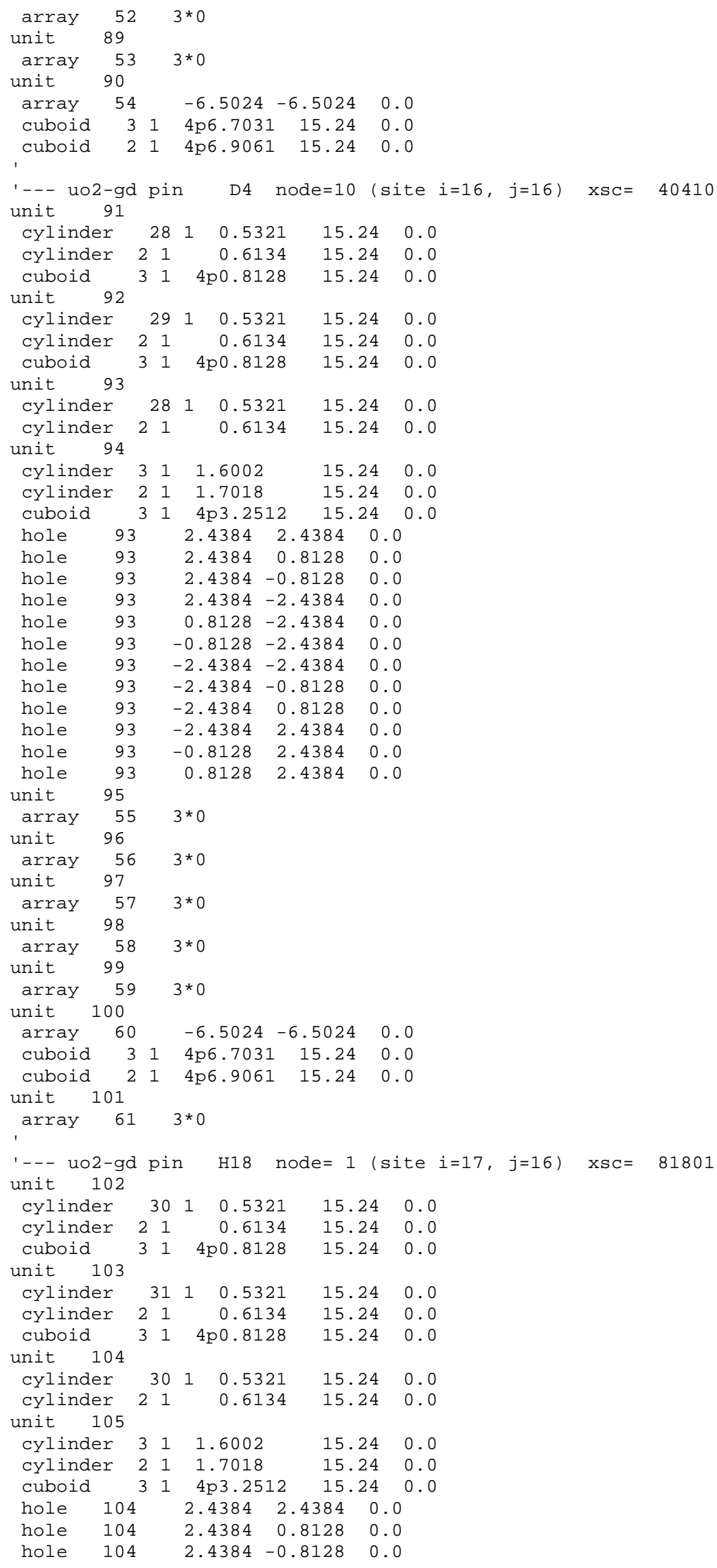




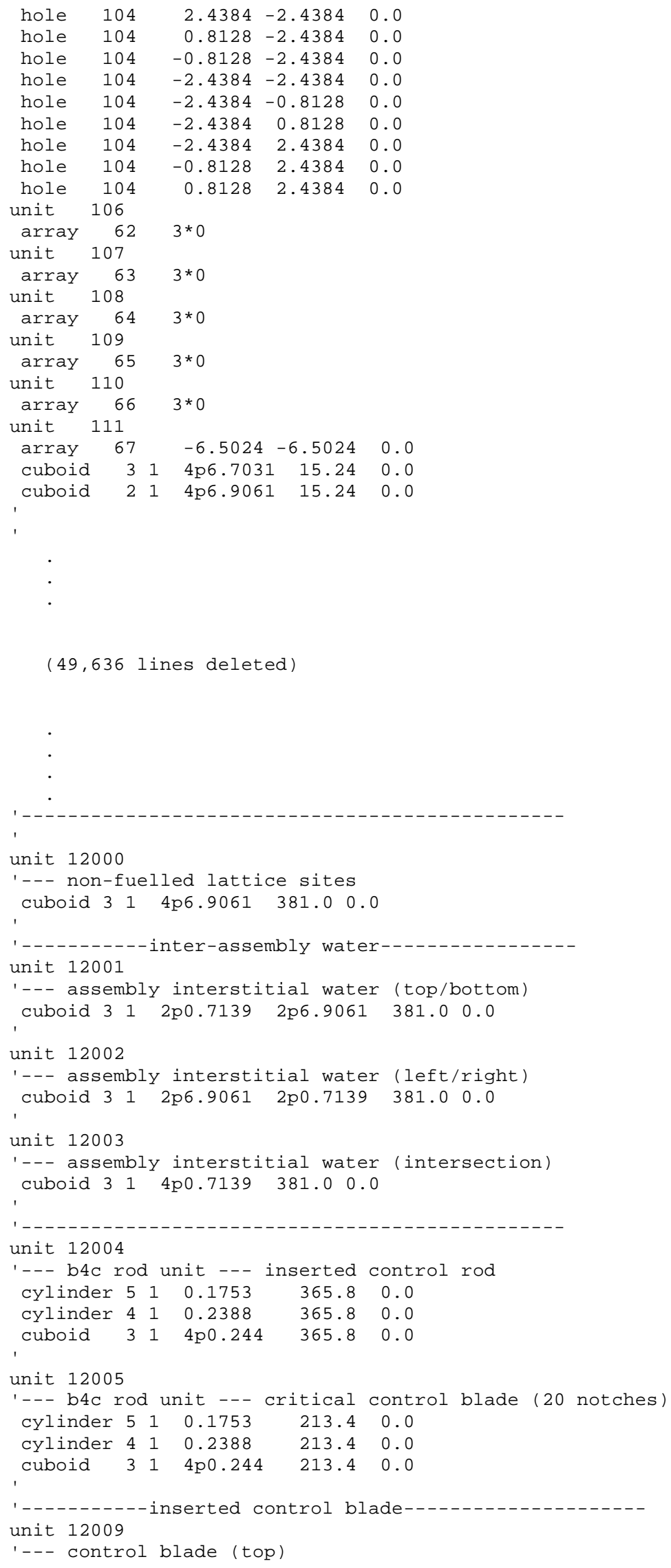




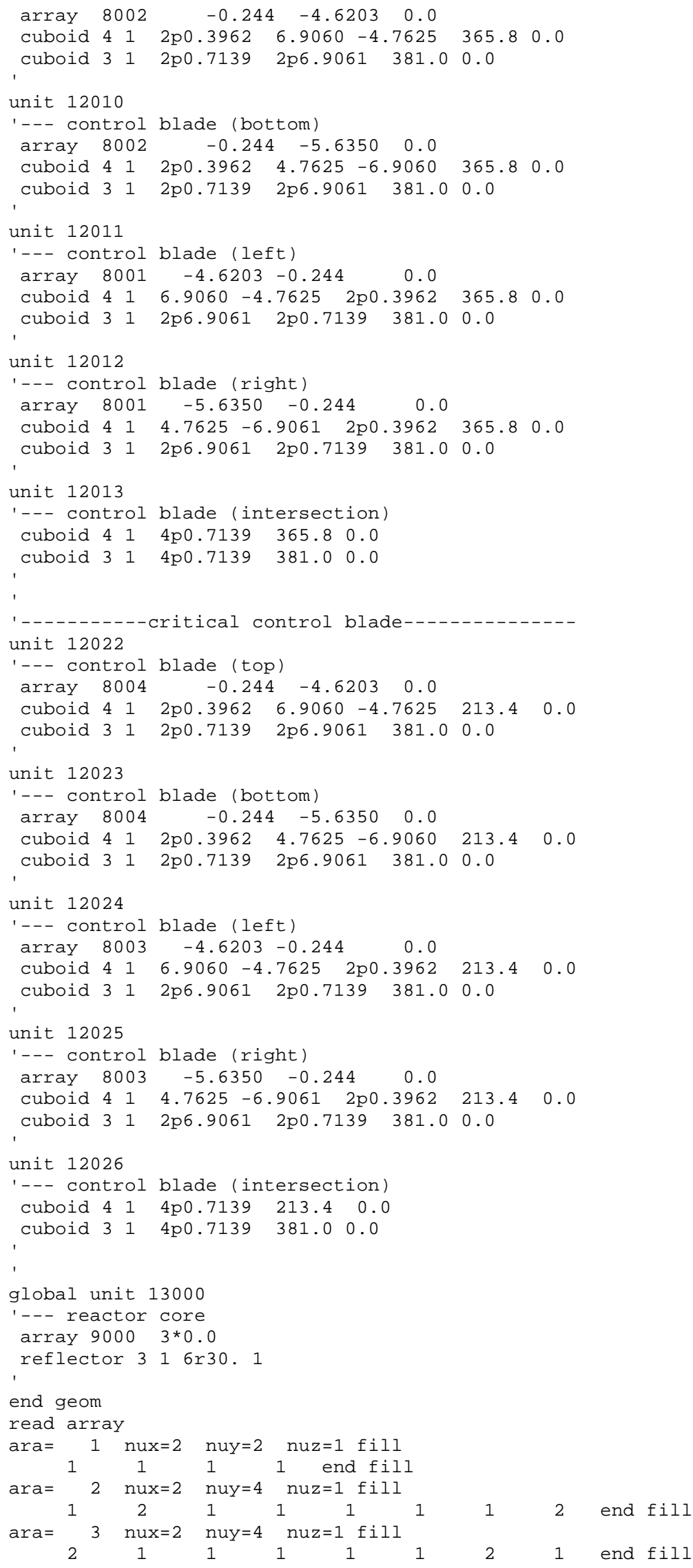




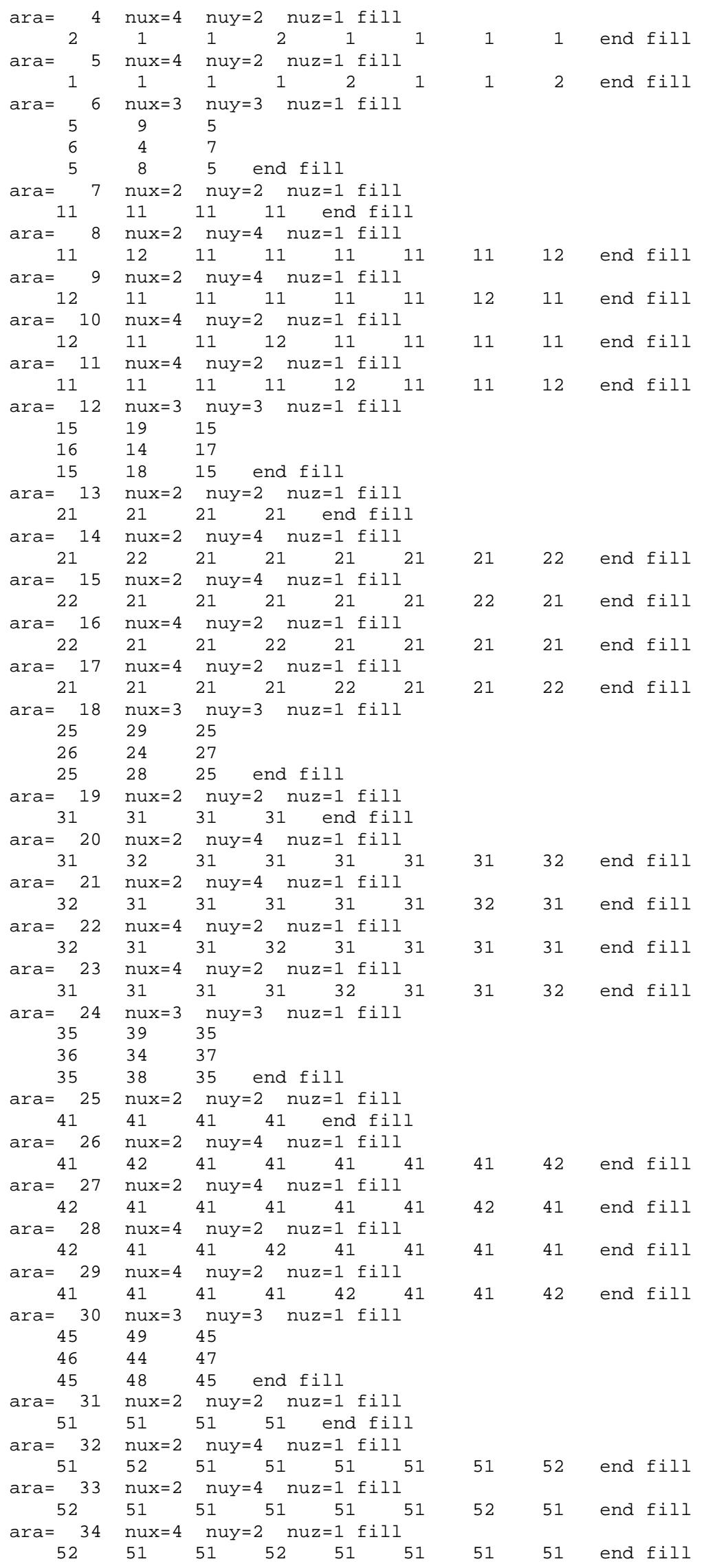




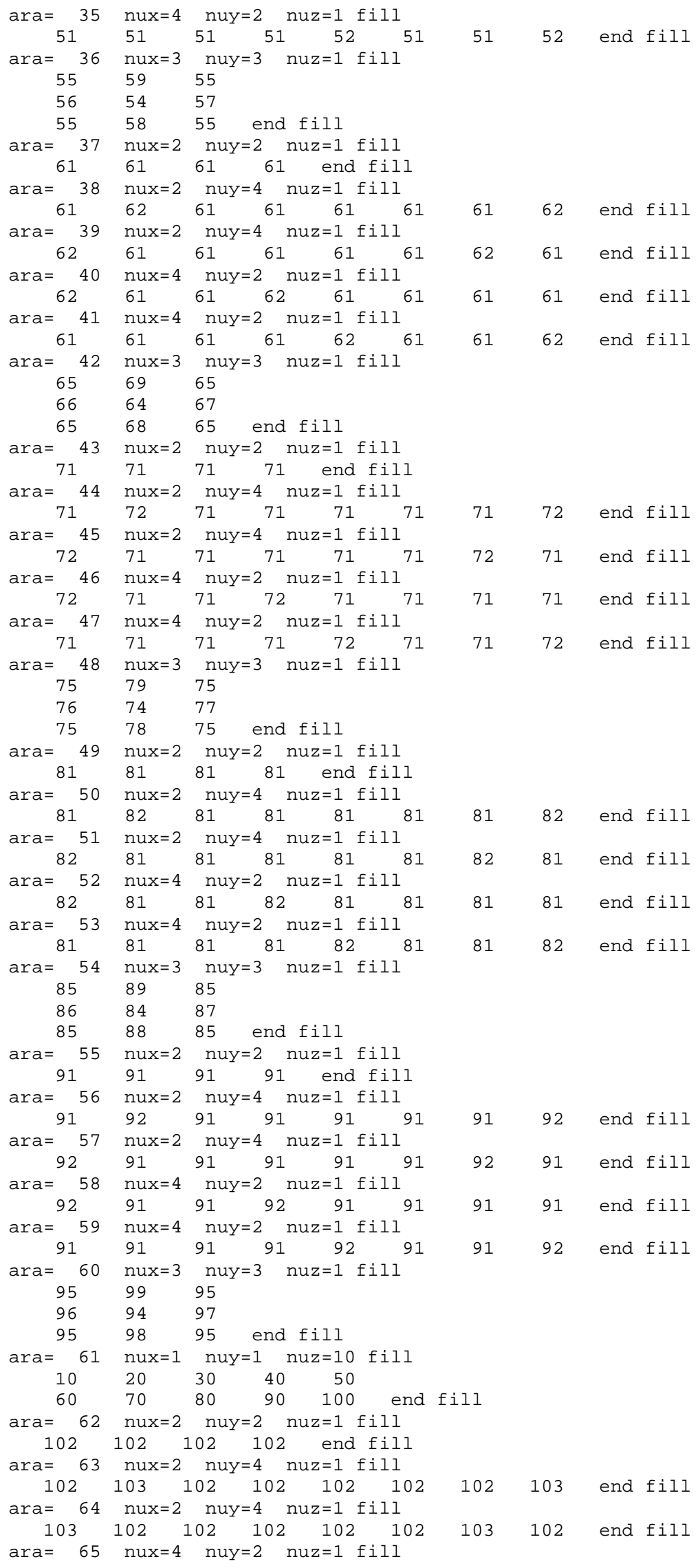




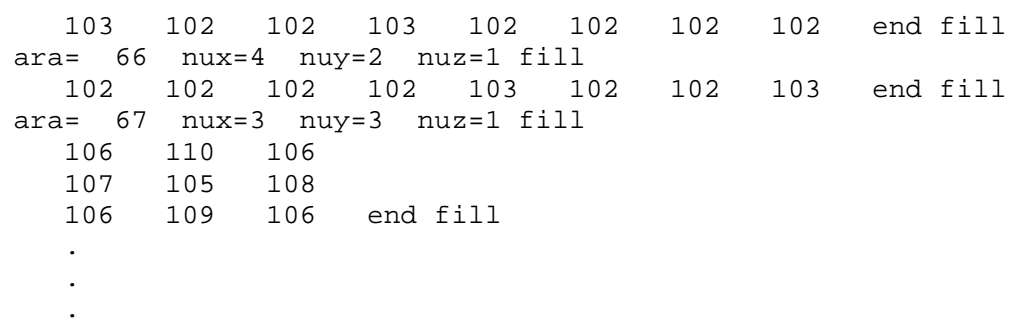

$(16,431$ lines deleted)

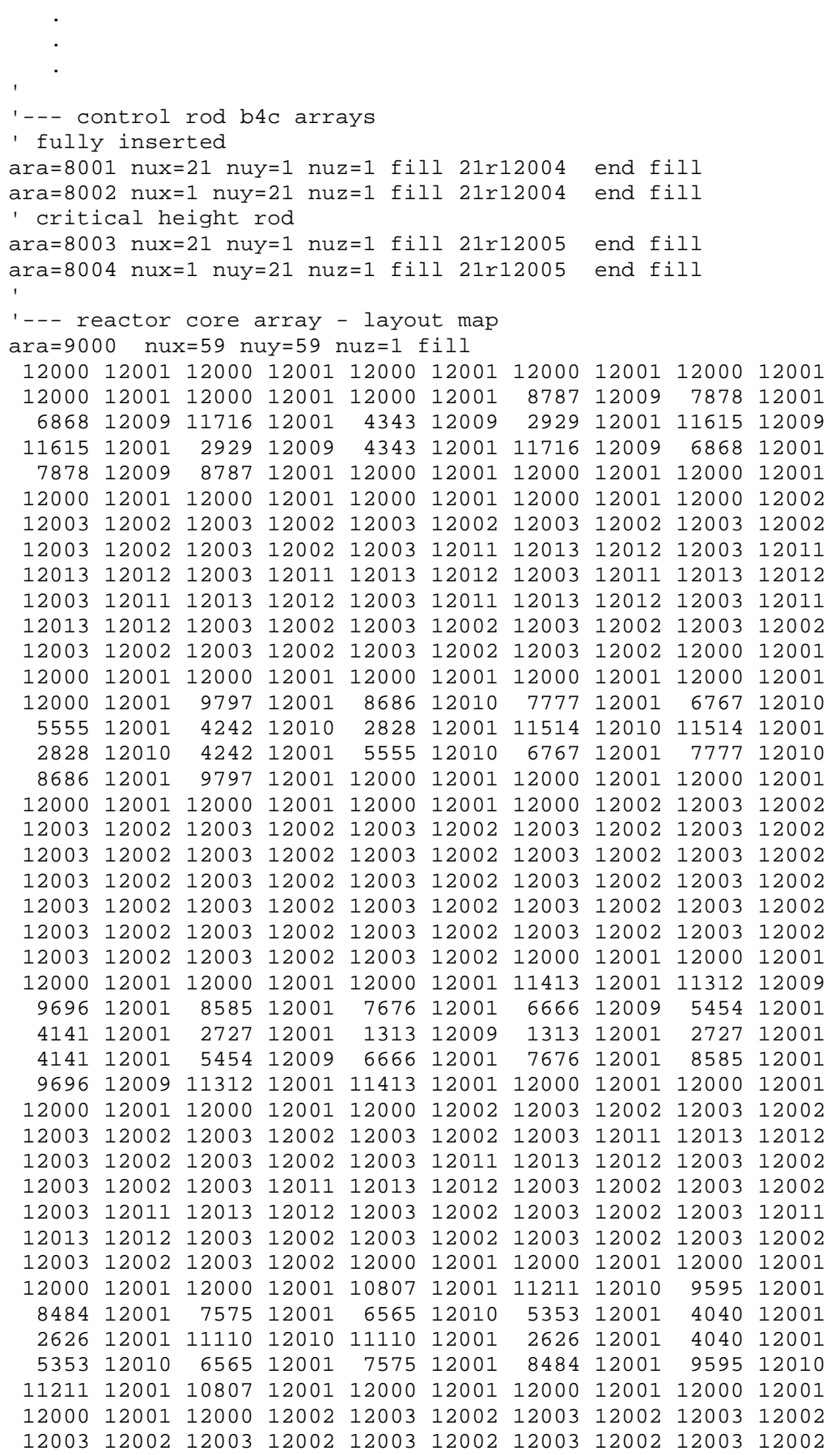


12003120021200312002120031200212003120021200312002 $1200312002 \quad 12003 \quad 12002 \quad 12003 \quad 12002 \quad 12003 \quad 12002 \quad 12003 \quad 12002$ $12003120021200312002 \quad 12003 \quad 1200212003 \quad 12002 \quad 1200312002$ 12003120021200312002120031200212003120021200312002 $12003120021200012001 \quad 1200012001 \quad 1200012001 \quad 1200012001$

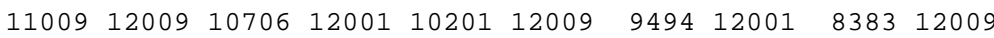
$\begin{array}{llllllllll}7474 & 12001 & 6464 & 12009 & 5252 & 12001 & 3939 & 12009 & 2525 & 12001\end{array}$ $\begin{array}{llllllllll}1111 & 12009 & 1111 & 12001 & 2525 & 12009 & 3939 & 12001 & 5252 & 12009\end{array}$ $\begin{array}{lllllllllll}6464 & 12001 & 7474 & 12009 & 8383 & 12001 & 9494 & 12009 & 10201 & 12001\end{array}$ $10706120091100912001 \quad 1200012001 \quad 1200012001 \quad 1200012001$ $1200012002120031200212003 \quad 12002 \quad 12003 \quad 12002 \quad 1200312011$ $12013120121200312011 \quad 12013120121200312011 \quad 1201312012$ $\begin{array}{lllllllllll}12003 & 12011 & 12013 & 12012 & 12003 & 12011 & 12013 & 12012 & 12003 & 12011\end{array}$ $\begin{array}{llllllllll}12013 & 12012 & 12003 & 12011 & 12013 & 12012 & 12003 & 12011 & 12013 & 12012\end{array}$ $\begin{array}{llllllllll}12003 & 12011 & 12013 & 12012 & 12003 & 12011 & 12013 & 12012 & 12003 & 12011\end{array}$ $120131201212003120021200312002 \quad 12003120021200312002$ $1200012001120001200110908120011080712001 \quad 1070612010$ $\begin{array}{llllllllll}10605 & 12001 & 10100 & 12010 & 9393 & 12001 & 8282 & 12010 & 7373 & 12001\end{array}$ $\begin{array}{lllllllllll}6363 & 12010 & 5151 & 12001 & 3838 & 12010 & 10504 & 12001 & 1010 & 12010\end{array}$ $\begin{array}{llllllllll}1010 & 12001 & 10504 & 12010 & 3838 & 12001 & 5151 & 12010 & 6363 & 12001\end{array}$ $\begin{array}{lllllllllll}7373 & 12010 & 8282 & 12001 & 9393 & 12010 & 10100 & 12001 & 10605 & 12010\end{array}$ $\begin{array}{lllllllllll}10706 & 12001 & 10807 & 12001 & 10908 & 12001 & 12000 & 12001 & 12000 & 12002\end{array}$ $1200312002120031200212003 \quad 12002 \quad 12003120021200312002$ $1200312002120031200212003 \quad 12002 \quad 12003120021200312002$ $1200312002120031200212003 \quad 12002 \quad 12003 \quad 120021200312002$ $1200312002120031200212003 \quad 12002 \quad 12003 \quad 12002 \quad 1200312002$ $120031200212003 \quad 1200212003 \quad 12002 \quad 12003 \quad 12002 \quad 1200312002$ 12003120021200312002120031200212003120021200012001 $1200012001 \quad 10403 \quad 120091030212001 \quad 10201 \quad 12001 \quad 1010012001$ $\begin{array}{lllllllllll}9999 & 12009 & 9292 & 12001 & 8181 & 12001 & 7272 & 12001 & 6262 & 12009\end{array}$ $\begin{array}{llllllllll}9898 & 12001 & 3737 & 12001 & 2323 & 12001 & 909 & 12009 & 909 & 12001\end{array}$ $\begin{array}{llllllllll}2323 & 12001 & 3737 & 12001 & 9898 & 12009 & 6262 & 12001 & 7272 & 12001\end{array}$ $\begin{array}{llllllllll}8181 & 12001 & 9292 & 12009 & 9999 & 12001 & 10100 & 12001 & 10201 & 12001\end{array}$ $\begin{array}{llllllllll}10302 & 12009 & 10403 & 12001 & 12000 & 12001 & 12000 & 12002 & 12003 & 12002\end{array}$ $1200312011120131201212003 \quad 12002 \quad 12003120021200312011$ $12013120121200312002 \quad 12003 \quad 120021200312011 \quad 1201312012$ $120031200212003120021200312011 \quad 12013120121200312002$ $\begin{array}{lllllllllll}12003 & 12002 & 12003 & 12011 & 12013 & 12012 & 12003 & 12002 & 12003 & 12002\end{array}$ $1200312011120131201212003 \quad 12002 \quad 12003 \quad 120021200312011$ $\begin{array}{lllllllllll}12013 & 12012 & 12003 & 12002 & 12003 & 12002 & 12000 & 12001 & 9797 & 12001\end{array}$ $\begin{array}{llllllllll}9696 & 12010 & 9595 & 12001 & 9494 & 12001 & 9393 & 12001 & 9292 & 12010\end{array}$ $\begin{array}{llllllllll}9191 & 12001 & 8080 & 12001 & 9090 & 12001 & 6161 & 12010 & 8989 & 12001\end{array}$ $\begin{array}{llllllllll}3636 & 12001 & 8888 & 12001 & 808 & 12010 & 808 & 12001 & 8888 & 12001\end{array}$ $\begin{array}{llllllllll}3636 & 12001 & 8989 & 12010 & 6161 & 12001 & 9090 & 12001 & 8080 & 12001\end{array}$ $\begin{array}{llllllllll}9191 & 12010 & 9292 & 12001 & 9393 & 12001 & 9494 & 12001 & 9595 & 12010\end{array}$ $\begin{array}{lllllllllll}9696 & 12001 & 9797 & 12001 & 12000 & 12002 & 12003 & 12002 & 12003 & 12002\end{array}$ $1200312002120031200212003 \quad 1200212003 \quad 120021200312002$ $\begin{array}{llllllllll}12003 & 12002 & 12003 & 12002 & 12003 & 12002 & 12003 & 12002 & 12003 & 12002\end{array}$ $12003120021200312002 \quad 12003 \quad 12002 \quad 12003 \quad 12002 \quad 12003 \quad 12002$ $120031200212003 \quad 1200212003 \quad 12002 \quad 12003 \quad 12002 \quad 1200312002$ $120031200212003 \quad 1200212003 \quad 12002 \quad 12003 \quad 12002 \quad 1200312002$

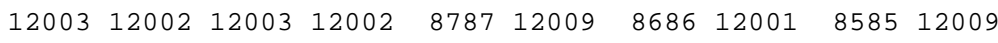
$\begin{array}{llllllllll}8484 & 12001 & 8383 & 12009 & 8282 & 12001 & 8181 & 12009 & 8080 & 12001\end{array}$ $\begin{array}{llllllllll}7979 & 12009 & 7070 & 12001 & 6060 & 12009 & 4848 & 12001 & 3535 & 12009\end{array}$ $\begin{array}{llllllllll}2121 & 12001 & 707 & 12009 & 707 & 12001 & 2121 & 12009 & 3535 & 12001\end{array}$ $\begin{array}{llllllllll}4848 & 12009 & 6060 & 12001 & 7070 & 12009 & 7979 & 12001 & 8080 & 12009\end{array}$ $\begin{array}{llllllllll}8181 & 12001 & 8282 & 12009 & 8383 & 12001 & 8484 & 12009 & 8585 & 12001\end{array}$ $\begin{array}{llllllllll}8686 & 12009 & 8787 & 12011 & 12013 & 12012 & 12003 & 12011 & 12013 & 12012\end{array}$ $\begin{array}{llllllllll}12003 & 12011 & 12013 & 12012 & 12003 & 12011 & 12013 & 12012 & 12003 & 12011\end{array}$ $12013120121200312011 \quad 12013120121200312011 \quad 1201312012$ $\begin{array}{llllllllll}12003 & 12011 & 12013 & 12012 & 12003 & 12011 & 12013 & 12012 & 12003 & 12011\end{array}$ $12013120121200312011 \quad 12013 \quad 1201212003 \quad 12011 \quad 12013 \quad 12012$ $120031201112013120121200312011 \quad 12013120121200312011$ $\begin{array}{lllllllllll}12013 & 12012 & 7878 & 12010 & 7777 & 12001 & 7676 & 12010 & 7575 & 12001\end{array}$ $\begin{array}{llllllllll}7474 & 12010 & 7373 & 12001 & 7272 & 12010 & 7171 & 12001 & 7070 & 12010\end{array}$ $\begin{array}{llllllllll}6969 & 12001 & 5959 & 12010 & 4747 & 12001 & 3434 & 12010 & 2020 & 12001\end{array}$ $\begin{array}{llllllllll}606 & 12010 & 606 & 12001 & 2020 & 12010 & 3434 & 12001 & 4747 & 12010\end{array}$ $\begin{array}{llllllllll}5959 & 12001 & 6969 & 12010 & 7070 & 12001 & 7171 & 12010 & 7272 & 12001\end{array}$ $\begin{array}{llllllllll}7373 & 12010 & 7474 & 12001 & 7575 & 12010 & 7676 & 12001 & 7777 & 12010\end{array}$ $\begin{array}{lllllllllll}7878 & 12002 & 12003 & 12002 & 12003 & 12002 & 12003 & 12002 & 12003 & 12002\end{array}$ $\begin{array}{lllllllllll}12003 & 12002 & 12003 & 12002 & 12003 & 12002 & 12003 & 12002 & 12003 & 12002\end{array}$ $1200312002120031200212003 \quad 1200212003 \quad 120021200312002$ 
12003120021200312002120031200212003120021200312002 $1200312002 \quad 12003 \quad 12002 \quad 12003 \quad 12002 \quad 12003 \quad 12002 \quad 12003 \quad 12002$ $1200312002120031200212003 \quad 1200212003120021200312002$ $\begin{array}{llllllllll}6868 & 12001 & 6767 & 12001 & 6666 & 12009 & 6565 & 12001 & 6464 & 12001\end{array}$ $\begin{array}{llllllllll}6363 & 12001 & 6262 & 12009 & 6161 & 12001 & 6060 & 12001 & 5959 & 12001\end{array}$

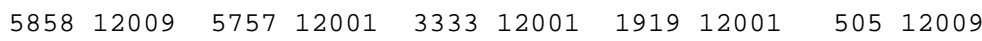
$\begin{array}{llllllllll}505 & 12001 & 1919 & 12009 & 3333 & 12001 & 5757 & 12009 & 5858 & 12001\end{array}$ $\begin{array}{lllllllllll}5959 & 12001 & 6060 & 12001 & 6161 & 12009 & 6262 & 12001 & 6363 & 12001\end{array}$ $\begin{array}{lllllllllll}6464 & 12001 & 6565 & 12009 & 6666 & 12001 & 6767 & 12001 & 6868 & 12002\end{array}$ $1200312002120031201112013 \quad 1201212003120021200312002$ $1200312011120131201212003 \quad 12002 \quad 1200312002 \quad 1200312011$ $120131201212003120021200312002 \quad 1200312011 \quad 1201312012$ $\begin{array}{lllllllllll}12003 & 12011 & 12013 & 12012 & 12003 & 12011 & 12013 & 12012 & 12003 & 12002\end{array}$ 12003120021200312011120131201212003120021200312002 $\begin{array}{llllllllll}12003 & 12011 & 12013 & 12012 & 12003 & 12002 & 12003 & 12002 & 5656 & 12001\end{array}$ $\begin{array}{lllllllllll}5555 & 12001 & 5454 & 12010 & 5353 & 12001 & 5252 & 12001 & 5151 & 12001\end{array}$ $\begin{array}{lllllllllll}5050 & 12010 & 4949 & 12001 & 4848 & 12001 & 4747 & 12001 & 4646 & 12010\end{array}$ $\begin{array}{llllllllll}4545 & 12001 & 3232 & 12001 & 4444 & 12001 & 404 & 12010 & 404 & 12001\end{array}$ $\begin{array}{llllllllll}4444 & 12010 & 3232 & 12001 & 4545 & 12010 & 4646 & 12001 & 4747 & 12001\end{array}$ $\begin{array}{llllllllll}4848 & 12001 & 4949 & 12010 & 5050 & 12001 & 5151 & 12001 & 5252 & 12001\end{array}$ $\begin{array}{llllllllll}5353 & 12010 & 5454 & 12001 & 5555 & 12001 & 5656 & 12002 & 12003 & 12002\end{array}$ $120031200212003 \quad 1200212003 \quad 12002 \quad 12003 \quad 12002 \quad 1200312002$ $12003120021200312002 \quad 12003 \quad 12002 \quad 12003 \quad 12002 \quad 12003 \quad 12002$ $1200312002120031200212003 \quad 12002 \quad 12003120021200312002$ $1200312002120031200212003 \quad 12002 \quad 12003 \quad 12002 \quad 12003 \quad 12002$ $1200312002120031200212003 \quad 12002 \quad 12003 \quad 12002 \quad 1200312002$ $\begin{array}{llllllllll}12003 & 12002 & 12003 & 12002 & 12003 & 12002 & 4343 & 12009 & 4242 & 12001\end{array}$

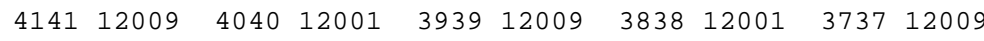
$\begin{array}{llllllllll}3636 & 12001 & 3535 & 12009 & 3434 & 12001 & 3333 & 12009 & 3232 & 12001\end{array}$ $\begin{array}{llllllllll}3131 & 12009 & 1717 & 12001 & 3030 & 12009 & 3030 & 12001 & 1717 & 12009\end{array}$ $\begin{array}{llllllllll}3131 & 12001 & 3232 & 12009 & 3333 & 12001 & 3434 & 12009 & 3535 & 12001\end{array}$ $\begin{array}{llllllllll}3636 & 12009 & 3737 & 12001 & 3838 & 12009 & 3939 & 12001 & 4040 & 12009\end{array}$ $\begin{array}{llllllllll}4141 & 12001 & 4242 & 12009 & 4343 & 12011 & 12013 & 12012 & 12003 & 12011\end{array}$

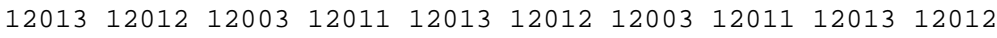
$120031201112013120121200312011 \quad 12013120121200312011$ $12013120121200312011 \quad 12013120121200312011 \quad 1201312012$ $120031201112013120121200312011 \quad 12013120121200312011$ $12013120121200312011 \quad 12013 \quad 12012 \quad 1200312011 \quad 1201312012$ $\begin{array}{llllllllll}12003 & 12011 & 12013 & 12012 & 2929 & 12010 & 2828 & 12001 & 2727 & 12010\end{array}$ $\begin{array}{llllllllll}2626 & 12001 & 2525 & 12010 & 2424 & 12001 & 2323 & 12010 & 2222 & 12001\end{array}$ $\begin{array}{llllllllll}2121 & 12010 & 2020 & 12001 & 1919 & 12010 & 1818 & 12001 & 1717 & 12010\end{array}$ $\begin{array}{llllllllll}1616 & 12001 & 202 & 12010 & 202 & 12001 & 1616 & 12010 & 1717 & 12001\end{array}$ $\begin{array}{llllllllll}1818 & 12010 & 1919 & 12001 & 2020 & 12010 & 2121 & 12001 & 2222 & 12010\end{array}$ $\begin{array}{llllllllll}2323 & 12001 & 2424 & 12010 & 2525 & 12001 & 2626 & 12010 & 2727 & 12001\end{array}$ $\begin{array}{lllllllllll}2828 & 12010 & 2929 & 12002 & 12003 & 12002 & 12003 & 12002 & 12003 & 12002\end{array}$ $1200312002120031200212003 \quad 12002 \quad 1200312002 \quad 1200312002$ $120031200212003 \quad 1200212003 \quad 12002 \quad 12003 \quad 12002 \quad 1200312002$ $1200312002120031200212003 \quad 12002 \quad 12003 \quad 12002 \quad 12003 \quad 12002$ $12003120021200312002 \quad 12003 \quad 12002 \quad 12003 \quad 12002 \quad 12003 \quad 12002$ $120031200212003 \quad 1200212003 \quad 12002 \quad 12003 \quad 12002 \quad 1200312002$ $\begin{array}{llllllllll}12003 & 12002 & 1515 & 12001 & 1414 & 12001 & 1313 & 12009 & 1212 & 12001\end{array}$ $\begin{array}{llllllllll}1111 & 12001 & 1010 & 12001 & 909 & 12009 & 808 & 12001 & 707 & 12001\end{array}$ $\begin{array}{llllllllll}606 & 12001 & 505 & 12009 & 404 & 12001 & 303 & 12001 & 202 & 12001\end{array}$ $\begin{array}{llllllllll}101 & 12009 & 101 & 12001 & 202 & 12001 & 303 & 12001 & 404 & 12009\end{array}$ $\begin{array}{llllllllll}505 & 12001 & 606 & 12001 & 707 & 12001 & 808 & 12009 & 909 & 12001\end{array}$ $\begin{array}{llllllllll}1010 & 12001 & 1111 & 12001 & 1212 & 12009 & 1313 & 12001 & 1414 & 12001\end{array}$ $\begin{array}{llllllllll}1515 & 12002 & 12003 & 12002 & 12003 & 12011 & 12013 & 12012 & 12003 & 12002\end{array}$ $12003120021200312011 \quad 120131201212003120021200312002$ $120031201112013120121200312002 \quad 12003120021200312011$ $120131201212003120021200312002 \quad 1200312011 \quad 1201312012$ $120031200212003 \quad 120021200312011 \quad 12013 \quad 1201212003 \quad 12002$ $12003120021200312011 \quad 12013 \quad 1201212003 \quad 12002 \quad 1200312002$ $\begin{array}{llllllllll}1515 & 12001 & 1414 & 12001 & 1313 & 12010 & 1212 & 12001 & 1111 & 12001\end{array}$

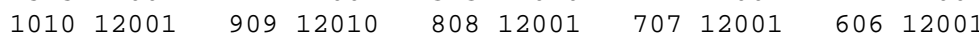

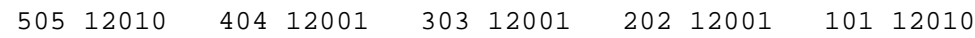

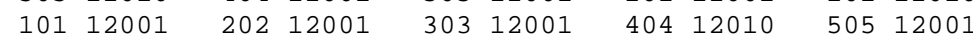
$\begin{array}{llllllllll}606 & 12001 & 707 & 12001 & 808 & 12010 & 909 & 12001 & 1010 & 12001\end{array}$ $\begin{array}{llllllllll}1111 & 12001 & 1212 & 12010 & 1313 & 12001 & 1414 & 12001 & 1515 & 12002\end{array}$ $1200312002120031200212003 \quad 12002 \quad 12003120021200312002$ $1200312002120031200212003 \quad 12002 \quad 12003120021200312002$ $\begin{array}{lllllllllll}12003 & 12002 & 12003 & 12002 & 12003 & 12002 & 12003 & 12002 & 12003 & 12002\end{array}$ $1200312002120031200212003 \quad 12002 \quad 12003 \quad 120021200312002$ 
12003120021200312002120031200212003120021200312002 $\begin{array}{llllllllll}12003 & 12002 & 12003 & 12002 & 12003 & 12002 & 12003 & 12002 & 2929 & 12009\end{array}$ $\begin{array}{llllllllll}2828 & 12001 & 2727 & 12009 & 2626 & 12001 & 2525 & 12009 & 2424 & 12001\end{array}$ $\begin{array}{llllllllll}2323 & 12009 & 2222 & 12001 & 2121 & 12009 & 2020 & 12001 & 1919 & 12009\end{array}$ $\begin{array}{llllllllll}1818 & 12001 & 1717 & 12009 & 1616 & 12001 & 202 & 12009 & 202 & 12001\end{array}$ $\begin{array}{llllllllll}1616 & 12009 & 1717 & 12001 & 1818 & 12009 & 1919 & 12001 & 2020 & 12009\end{array}$ $\begin{array}{llllllllll}2121 & 12001 & 2222 & 12009 & 2323 & 12001 & 2424 & 12009 & 2525 & 12001\end{array}$

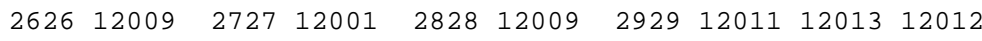
$\begin{array}{llllllllll}12003 & 12011 & 12013 & 12012 & 12003 & 12011 & 12013 & 12012 & 12003 & 12011\end{array}$ $12013120121200312011 \quad 12013 \quad 120121200312011 \quad 1201312012$ $\begin{array}{lllllllllll}12003 & 12011 & 12013 & 12012 & 12003 & 12011 & 12013 & 12012 & 12003 & 12011\end{array}$ 12013120121200312011120131201212003120111201312012 $\begin{array}{llllllllll}12003 & 12011 & 12013 & 12012 & 12003 & 12011 & 12013 & 12012 & 12003 & 12011\end{array}$ $\begin{array}{llllllllll}12013 & 12012 & 12003 & 12011 & 12013 & 12012 & 4343 & 12010 & 4242 & 12001\end{array}$ $\begin{array}{llllllllll}4141 & 12010 & 4040 & 12001 & 3939 & 12010 & 3838 & 12001 & 3737 & 12010\end{array}$ $\begin{array}{llllllllll}3636 & 12001 & 3535 & 12010 & 3434 & 12001 & 3333 & 12010 & 3232 & 12001\end{array}$ $\begin{array}{llllllllll}3131 & 12010 & 1717 & 12001 & 3030 & 12010 & 3030 & 12001 & 1717 & 12010\end{array}$ $\begin{array}{llllllllll}3131 & 12001 & 3232 & 12010 & 3333 & 12001 & 3434 & 12010 & 3535 & 12001\end{array}$ $\begin{array}{lllllllllll}3636 & 12010 & 3737 & 12001 & 3838 & 12010 & 3939 & 12001 & 4040 & 12010\end{array}$ $\begin{array}{lllllllllll}4141 & 12001 & 4242 & 12010 & 4343 & 12002 & 12003 & 12002 & 12003 & 12002\end{array}$ $1200312002120031200212003 \quad 12002 \quad 12003120021200312002$ $12003120021200312002 \quad 12003 \quad 12002 \quad 12003 \quad 12002 \quad 12003 \quad 12002$ $\begin{array}{lllllllllll}12003 & 12002 & 12003 & 12002 & 12003 & 12002 & 12003 & 12002 & 12003 & 12002\end{array}$ $1200312002120031200212003 \quad 12002 \quad 12003120021200312002$ $1200312002120031200212003 \quad 12002 \quad 1200312002 \quad 1200312002$ $\begin{array}{llllllllll}12003 & 12002 & 12003 & 12002 & 5656 & 12001 & 5555 & 12001 & 5454 & 12009\end{array}$ $\begin{array}{lllllllllll}5353 & 12001 & 5252 & 12001 & 5151 & 12001 & 5050 & 12009 & 4949 & 12001\end{array}$ $\begin{array}{llllllllll}4848 & 12001 & 4747 & 12001 & 4646 & 12009 & 4545 & 12001 & 3232 & 12022\end{array}$ $\begin{array}{lllllllllll}4444 & 12001 & 404 & 12009 & 404 & 12001 & 4444 & 12009 & 3232 & 12001\end{array}$ $\begin{array}{lllllllllll}454512009 & 4646 & 12001 & 4747 & 12001 & 4848 & 12001 & 4949 & 12009\end{array}$ $\begin{array}{llllllllll}5050 & 12001 & 5151 & 12001 & 5252 & 12001 & 5353 & 12009 & 5454 & 12001\end{array}$ $\begin{array}{llllllllll}5555 & 12001 & 5656 & 12002 & 12003 & 12002 & 12003 & 12011 & 12013 & 12012\end{array}$ $\begin{array}{llllllllll}12003 & 12002 & 12003 & 12002 & 12003 & 12011 & 12013 & 12012 & 12003 & 12002\end{array}$ $\begin{array}{lllllllllll}12003 & 12002 & 12003 & 12011 & 12013 & 12012 & 12003 & 12024 & 12026 & 12025\end{array}$

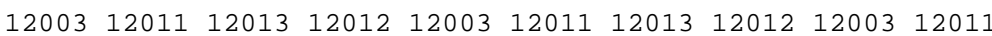
$\begin{array}{llllllllll}12013 & 12012 & 12003 & 12002 & 12003 & 12002 & 12003 & 12011 & 12013 & 12012\end{array}$ $120031200212003 \quad 120021200312011 \quad 120131201212003 \quad 12002$ $\begin{array}{llllllllll}12003 & 12002 & 6868 & 12001 & 6767 & 12001 & 6666 & 12010 & 6565 & 12001\end{array}$ $\begin{array}{lllllllllll}6464 & 12001 & 6363 & 12001 & 6262 & 12010 & 6161 & 12001 & 6060 & 12001\end{array}$ $\begin{array}{llllllllll}5959 & 12001 & 5858 & 12010 & 5757 & 12001 & 3333 & 12023 & 1919 & 12001\end{array}$ $\begin{array}{llllllllll}505 & 12010 & 505 & 12001 & 1919 & 12010 & 3333 & 12001 & 5757 & 12010\end{array}$ $\begin{array}{llllllllll}5858 & 12001 & 5959 & 12001 & 6060 & 12001 & 6161 & 12010 & 6262 & 12001\end{array}$ $\begin{array}{lllllllllll}6363 & 12001 & 6464 & 12001 & 6565 & 12010 & 6666 & 12001 & 6767 & 12001\end{array}$ $\begin{array}{llllllllll}6868 & 12002 & 12003 & 12002 & 12003 & 12002 & 12003 & 12002 & 12003 & 12002\end{array}$ $\begin{array}{lllllllllll}12003 & 12002 & 12003 & 12002 & 12003 & 12002 & 12003 & 12002 & 12003 & 12002\end{array}$ $\begin{array}{lllllllllll}12003 & 12002 & 12003 & 12002 & 12003 & 12002 & 12003 & 12002 & 12003 & 12002\end{array}$ $120031200212003 \quad 1200212003 \quad 12002 \quad 12003 \quad 12002 \quad 1200312002$ $120031200212003 \quad 1200212003 \quad 12002 \quad 12003 \quad 12002 \quad 12003 \quad 12002$ $12003120021200312002 \quad 12003 \quad 12002 \quad 12003 \quad 12002 \quad 12003 \quad 12002$ $\begin{array}{lllllllllll}7878 & 12009 & 7777 & 12001 & 7676 & 12009 & 7575 & 12001 & 7474 & 12009\end{array}$ $\begin{array}{llllllllll}7373 & 12001 & 7272 & 12009 & 7171 & 12001 & 7070 & 12009 & 6969 & 12001\end{array}$ $\begin{array}{llllllllll}5959 & 12009 & 4747 & 12001 & 3434 & 12009 & 2020 & 12001 & 606 & 12009\end{array}$ $\begin{array}{lllllllllll}606 & 12001 & 2020 & 12009 & 3434 & 12001 & 4747 & 12009 & 5959 & 12001\end{array}$ $\begin{array}{llllllllll}6969 & 12009 & 7070 & 12001 & 7171 & 12009 & 7272 & 12001 & 7373 & 12009\end{array}$ $\begin{array}{llllllllll}7474 & 12001 & 7575 & 12009 & 7676 & 12001 & 7777 & 12009 & 7878 & 12011\end{array}$ $12013120121200312011 \quad 12013 \quad 120121200312011 \quad 1201312012$ $\begin{array}{llllllllll}12003 & 12011 & 12013 & 12012 & 12003 & 12011 & 12013 & 12012 & 12003 & 12011\end{array}$ $12013120121200312011 \quad 12013 \quad 12012 \quad 12003 \quad 12011 \quad 1201312012$ $\begin{array}{llllllllll}12003 & 12011 & 12013 & 12012 & 12003 & 12011 & 12013 & 12012 & 12003 & 12011\end{array}$ $12013120121200312011 \quad 12013 \quad 12012 \quad 12003 \quad 12011 \quad 12013 \quad 12012$ $\begin{array}{llllllllll}12003 & 12011 & 12013 & 12012 & 12003 & 12011 & 12013 & 12012 & 8787 & 12010\end{array}$ $\begin{array}{llllllllll}8686 & 12001 & 8585 & 12010 & 8484 & 12001 & 8383 & 12010 & 8282 & 12001\end{array}$ $\begin{array}{lllllllllll}8181 & 12010 & 8080 & 12001 & 7979 & 12010 & 7070 & 12001 & 6060 & 12010\end{array}$ $\begin{array}{llllllllll}4848 & 12001 & 3535 & 12010 & 2121 & 12001 & 707 & 12010 & 707 & 12001\end{array}$ $\begin{array}{llllllllll}2121 & 12010 & 3535 & 12001 & 4848 & 12010 & 6060 & 12001 & 7070 & 12010\end{array}$ $\begin{array}{lllllllllll}7979 & 12001 & 8080 & 12010 & 8181 & 12001 & 8282 & 12010 & 8383 & 12001\end{array}$ $\begin{array}{lllllllllll}8484 & 12010 & 8585 & 12001 & 8686 & 12010 & 8787 & 12002 & 12003 & 12002\end{array}$ $1200312002120031200212003 \quad 12002 \quad 12003 \quad 12002 \quad 1200312002$ $12003120021200312002 \quad 12003 \quad 12002 \quad 12003 \quad 12002 \quad 12003 \quad 12002$ $1200312002120031200212003 \quad 12002 \quad 12003120021200312002$ $\begin{array}{lllllllllll}12003 & 12002 & 12003 & 12002 & 12003 & 12002 & 12003 & 12002 & 12003 & 12002\end{array}$ $1200312002120031200212003 \quad 12002 \quad 12003 \quad 120021200312002$ 
$120031200212003 \quad 12002 \quad 12003 \quad 12002 \quad 1200012001 \quad 979712001$ $\begin{array}{llllllllll}9696 & 12009 & 9595 & 12001 & 9494 & 12001 & 9393 & 12001 & 9292 & 12009\end{array}$ $\begin{array}{llllllllll}9191 & 12001 & 8080 & 12001 & 9090 & 12001 & 6161 & 12009 & 8989 & 12001\end{array}$

$\begin{array}{llllllllll}3636 & 12001 & 8888 & 12001 & 808 & 12009 & 808 & 12001 & 8888 & 12001\end{array}$ $\begin{array}{llllllllll}3636 & 12001 & 8989 & 12009 & 6161 & 12001 & 9090 & 12001 & 8080 & 12001\end{array}$

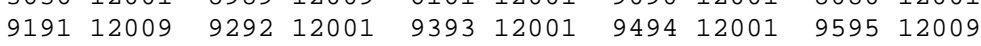

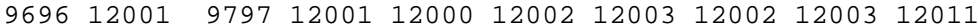
$\begin{array}{llllllllll}12013 & 12012 & 12003 & 12002 & 12003 & 12002 & 12003 & 12011 & 12013 & 12012\end{array}$

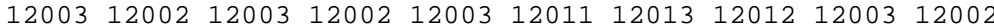
$\begin{array}{llllllllll}12003 & 12002 & 12003 & 12011 & 12013 & 12012 & 12003 & 12002 & 12003 & 12002\end{array}$ $1200312011 \quad 12013 \quad 1201212003 \quad 12002 \quad 12003 \quad 12002 \quad 1200312011$ $\begin{array}{llllllllll}12013 & 12012 & 12003 & 12002 & 12003 & 12002 & 12003 & 12011 & 12013 & 12012\end{array}$ $120031200212003120021200012001 \quad 1200012001 \quad 1040312010$ $\begin{array}{llllllllll}10302 & 12001 & 10201 & 12001 & 10100 & 12001 & 9999 & 12010 & 9292 & 12001\end{array}$ $\begin{array}{rlrlrlllll}8181 & 12001 & 7272 & 12001 & 6262 & 12010 & 9898 & 12001 & 3737 & 12001\end{array}$

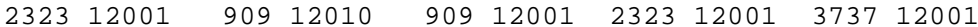
$\begin{array}{llllllllll}9898 & 12010 & 6262 & 12001 & 7272 & 12001 & 8181 & 12001 & 9292 & 12010\end{array}$ $999912001 \quad 1010012001 \quad 10201 \quad 12001 \quad 10302 \quad 120101040312001$ $1200012001 \quad 1200012002 \quad 12003 \quad 12002 \quad 12003 \quad 12002 \quad 1200312002$

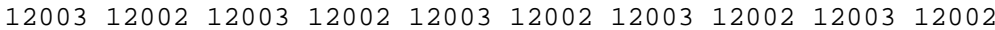
$\begin{array}{llllllllll}12003 & 12002 & 12003 & 12002 & 12003 & 12002 & 12003 & 12002 & 12003 & 12002\end{array}$ $120031200212003 \quad 12002 \quad 12003 \quad 12002 \quad 12003 \quad 12002 \quad 1200312002$ $120031200212003 \quad 12002 \quad 12003 \quad 12002 \quad 1200312002 \quad 1200312002$ $\begin{array}{lllllllllll}12003 & 12002 & 12003 & 12002 & 12003 & 12002 & 12003 & 12002 & 12003 & 12002\end{array}$ $12003 \quad 120021200012001 \quad 12000 \quad 12001 \quad 1090812001 \quad 10807 \quad 12001$

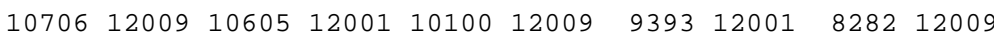
$\begin{array}{llllllllll}7373 & 12001 & 6363 & 12009 & 5151 & 12001 & 3838 & 12009 & 10504 & 12001\end{array}$ $\begin{array}{llllllllll}1010 & 12009 & 1010 & 12001 & 10504 & 12009 & 3838 & 12001 & 5151 & 12009\end{array}$

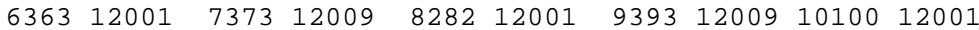
$10605120091070612001 \quad 10807 \quad 12001 \quad 10908 \quad 12001 \quad 1200012001$ $1200012002 \quad 12003 \quad 12002 \quad 12003 \quad 12002 \quad 12003 \quad 12002 \quad 1200312011$ $\begin{array}{llllllllll}12013 & 12012 & 12003 & 12011 & 12013 & 12012 & 12003 & 12011 & 12013 & 12012\end{array}$ $\begin{array}{llllllllll}12003 & 12011 & 12013 & 12012 & 12003 & 12011 & 12013 & 12012 & 12003 & 12011\end{array}$ $\begin{array}{llllllllll}12013 & 12012 & 12003 & 12011 & 12013 & 12012 & 12003 & 12011 & 12013 & 12012\end{array}$ $\begin{array}{llllllllll}12003 & 12011 & 12013 & 12012 & 12003 & 12011 & 12013 & 12012 & 12003 & 12011\end{array}$

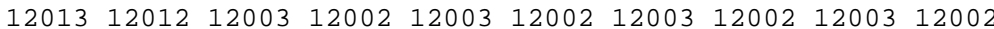
$1200012001 \quad 1200012001 \quad 12000 \quad 12001 \quad 12000 \quad 12001 \quad 1100912010$ $\begin{array}{llllllllll}10706 & 12001 & 10201 & 12010 & 9494 & 12001 & 8383 & 12010 & 7474 & 12001\end{array}$ $\begin{array}{llllllllll}6464 & 12010 & 5252 & 12001 & 3939 & 12010 & 2525 & 12001 & 1111 & 12010\end{array}$ $\begin{array}{llllllllll}1111 & 12001 & 2525 & 12010 & 3939 & 12001 & 5252 & 12010 & 6464 & 12001\end{array}$ $\begin{array}{lllllllllll}7474 & 12010 & 8383 & 12001 & 9494 & 12010 & 10201 & 12001 & 10706 & 12010\end{array}$ $1100912001 \quad 1200012001 \quad 1200012001 \quad 1200012001 \quad 1200012002$ $\begin{array}{llllllllll}12003 & 12002 & 12003 & 12002 & 12003 & 12002 & 12003 & 12002 & 12003 & 12002\end{array}$ $1200312002 \quad 12003 \quad 12002 \quad 12003 \quad 12002 \quad 12003 \quad 12002 \quad 12003 \quad 12002$ $\begin{array}{llllllllll}12003 & 12002 & 12003 & 12002 & 12003 & 12002 & 12003 & 12002 & 12003 & 12002\end{array}$ $1200312002 \quad 12003 \quad 12002 \quad 12003 \quad 12002 \quad 12003 \quad 12002 \quad 1200312002$

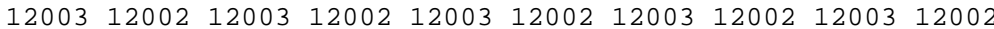
$120031200212003 \quad 12002 \quad 12003 \quad 12002 \quad 12003 \quad 12002 \quad 1200012001$ $1200012001 \quad 1200012001 \quad 1200012001 \quad 12000120011080712001$

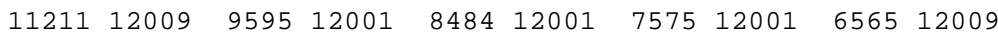
$\begin{array}{lllllllllll}5353 & 12001 & 4040 & 12001 & 2626 & 12001 & 11110 & 12009 & 11110 & 12001\end{array}$ $\begin{array}{llllllllll}2626 & 12001 & 4040 & 12001 & 5353 & 12009 & 6565 & 12001 & 7575 & 12001\end{array}$ $\begin{array}{lllllllllll}8484 & 12001 & 9595 & 12009 & 11211 & 12001 & 10807 & 12001 & 12000 & 12001\end{array}$ $1200012001 \quad 1200012001 \quad 1200012001 \quad 12000120021200312002$ $\begin{array}{llllllllll}12003 & 12002 & 12003 & 12002 & 12003 & 12002 & 12003 & 12002 & 12003 & 12011\end{array}$ $\begin{array}{llllllllll}12013 & 12012 & 12003 & 12002 & 12003 & 12002 & 12003 & 12011 & 12013 & 12012\end{array}$ $\begin{array}{lllllllllll}12003 & 12002 & 12003 & 12002 & 12003 & 12011 & 12013 & 12012 & 12003 & 12002\end{array}$

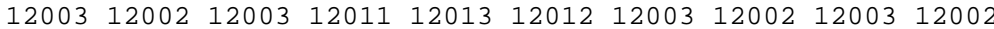
$\begin{array}{llllllllll}12003 & 12011 & 12013 & 12012 & 12003 & 12002 & 12003 & 12002 & 12003 & 12002\end{array}$ $\begin{array}{llllllllll}12003 & 12002 & 12003 & 12002 & 12003 & 12002 & 12000 & 12001 & 12000 & 12001\end{array}$ $1200012001 \quad 1200012001 \quad 12000 \quad 12001 \quad 11413 \quad 12001 \quad 1131212010$ $\begin{array}{llllllllll}9696 & 12001 & 8585 & 12001 & 7676 & 12001 & 6666 & 12010 & 5454 & 12001\end{array}$ $\begin{array}{llllllllll}4141 & 12001 & 2727 & 12001 & 1313 & 12010 & 1313 & 12001 & 2727 & 12001\end{array}$ $\begin{array}{llllllllll}4141 & 12001 & 5454 & 12010 & 6666 & 12001 & 7676 & 12001 & 8585 & 12001\end{array}$ $969612010 \quad 1131212001 \quad 11413 \quad 12001 \quad 12000 \quad 12001 \quad 12000 \quad 12001$ $1200012001 \quad 1200012001 \quad 12000 \quad 12002 \quad 12003 \quad 12002 \quad 1200312002$ $\begin{array}{llllllllll}12003 & 12002 & 12003 & 12002 & 12003 & 12002 & 12003 & 12002 & 12003 & 12002\end{array}$ $\begin{array}{llllllllll}12003 & 12002 & 12003 & 12002 & 12003 & 12002 & 12003 & 12002 & 12003 & 12002\end{array}$ $12003 \quad 12002 \quad 120031200212003 \quad 12002 \quad 12003 \quad 120021200312002$ $\begin{array}{llllllllll}12003 & 12002 & 12003 & 12002 & 12003 & 12002 & 12003 & 12002 & 12003 & 12002\end{array}$ $12003 \quad 12002 \quad 12003 \quad 12002 \quad 12003 \quad 12002 \quad 12003 \quad 12002 \quad 12003 \quad 12002$ $120031200212003120021200012001 \quad 1200012001 \quad 1200012001$ 


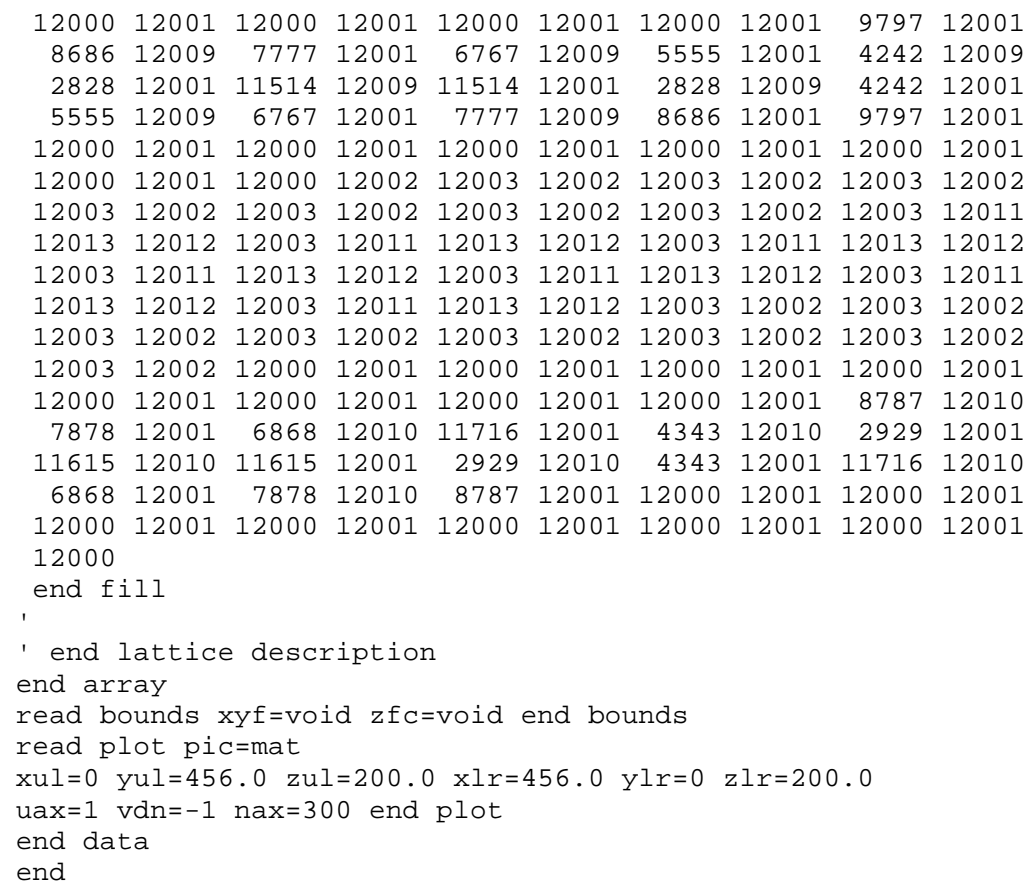





\section{INTERNAL DISTRIBUTION}

1. S. M. Bowman

2. B. L. Broadhead

3-8. W. C. Carter

9. M. D. DeHart

10. R. J. Ellis

11. M. B. Emmett

12-16. I. C. Gauld

17. J. C. Gehin

18. O. W. Hermann

19. D. T. Ingersoll

20. M. A. Kuliasha

21. S. K. Lichtenwalter

22. S. B. Ludwig

23. G. E. Michaels
24. B. D. Murphy

25-29. C. V. Parks

30. L. M. Petrie

31. R. T. Primm

32. R. W. Roussin

33. J. C. Ryman

34. C. H. Shappert

35. J. C. Wagner

36. R. M. Westfall

37. R. Q. Wright

38. Laboratory Records-RC

39-40. Laboratory Records for Submission to OSTI

41. Central Research Library

\section{EXTERNAL DISTRIBUTION}

42. M. G. Bailey, Office of Nuclear Material Safety \& Safeguards, U.S. Nuclear Regulatory Commission, MS 13 D13, Washington, DC 20555

43. L. Barrett, Office of Civilian Radioactive Waste Management, RW-232 20545, U.S. Department of Energy, Washington, DC 20545

44. C. J. Benson, Bettis Atomic Power Laboratory, P.O. Box 79, West Mifflin, PA 15122

45. M. C. Brady-Raap, P.O. Box 1950, MISN R1-43, Richland, WA 99352

46. R. J. Cacciapouti, Yankee Atomic Electric Co., 1617 Worcester Rd., Framington, MA 01701

47. D. E. Carlson, U.S. Nuclear Regulatory Commission, Spent Fuel Project Office, MS 13 D13, Washington, DC 20555

48. J. Clark, 2650 Park Tower Drive, Suite 800, Vienna, VA 22180

49. J. Conde, Consejo de Seguridad Nuclear, Justo Dorado, 11, 28040 Madrid, Spain

50. D. R. Conners, Bettis Atomic Power Laboratory, P.O. Box 79, West Mifflin, PA 15122

51. W. Davis, Framatome Cogema Fuels, 1261 Town Center Drive, Las Vegas, NV 89134

52. T. W. Doering, Framatome Cogema Fuels, 1261 Town Center Drive, Las Vegas, NV 89134

53. P. Finck, Argonne National Lab., 9700 S. Cass Ave., Bldg. 360, Argonne, IL 60439 
54. H. Geiser, Wissenschaftlich-Technische Ingenieurberatung GmbH, P.O. Box 13 40, 52410 Julich, Federal Republic of Germany

55. N. Gulliford, Winfrith Technology Centre, 306/A32, AEA Technology PLC, Winfrith, Dorchester, Dorset DT2 8DH

56. S. Hanauer, U.S. Department of Energy, RW-22, Washington, DC 20545

57. L. Hassler, Babcock \& Wilcox, P.O. Box 10935, Lynchburg, VA 24506-0935

58. D. Henderson, Framatome Cogema, 1261 Town Center Drive, Las Vegas, NV 89134

59. G. Kirchner, University of Bremen, FB 1 Postfach 330440, D-W-2800 Bremen 33, Federal Republic of Germany

60. C. Kouts, Office of Civilian Radioactive Waste Management, RW-36, U.S. Department of Energy, Washington, DC 20545

61. W. H. Lake, Office of Civilian Radioactive Waste Management, U.S. Department of Energy, RW-46, Washington, DC 20585

62. D. Lancaster, 2650 Park Tower Drive, Suite 800, Vienna, VA 22180

63. Y. L. Liu, Argonne National Laboratory, 9700 S. Cass Ave., Bldg.308, Argonne, IL 60439-4825

64. M. Mason, Transnuclear, Two Skyline Drive, Hawthorne, NY 10532-2120

65. A. Michaels, Electric Power Research Institute, 3412 Hillview Ave., Palo Alto, CA 94304

66. M. Mount, Lawrence Livermore National Laboratory, P.O. Box 808, Livermore, CA 94550

67. Dominic Napolitano, NISYS Corporation, 4233 Pleasant Hill Road, Suite 200, Duluth, GA 30096

68. C. W. Nilsen, Office of Nuclear Material Safety and Safeguards, U.S. Nuclear Regulatory Commission, MS 10 K8, Washington, DC 20555

69. P. Noel, Framatome Cogema, 1261 Town Center Drive, Las Vegas, NV 89134

70. Office of the Assistant Manager for Energy Research and Development, Department of Energy Oak Ridge Operations (DOE-ORO), P.O. Box 2008, Oak Ridge, TN 37831

71. N. L. Osgood, U.S. Nuclear Regulatory Commission, Office of Nuclear Materials Safety and Safeguards, MS 13 D13, Washington, DC 20555

72. O. Ozer, Electric Power Research Institute, 3412 Hillview Ave., Palo Alto, CA 94304

73. V. A. Perin, U.S. Nuclear Regulatory Commission, Office of Nuclear Materials Safety and Safeguards, MS T7 F3, Washington, DC 20555

74. M. Rahimi, U.S. Nuclear Regulatory Commission, Office of Nuclear Materials Safety and Safeguards, MS T7 F3, Washington, DC 20555

75. D. Salmon, Framatome Cogema, 1261 Town Center Drive, Las Vegas, NV 89134

76. E. Sartori, OECD Data Bank, 12 Bd des Iles, 92130 Issy-les-Moulineaux, France

77. M. Smith, U.S. Department of Energy, Yucca Mountain Project Office, 101 Convention Center Dr., Las Vegas, NV 89190

78. M. Smith, Virginia Power Co., P.O. Box 2666, Richmond, VA 23261

79. H. Taniuchi, Kobe Steel, Ltd., 2-3-1 Shinhama, Arai-Cho, Takasago, 676 Japan

80. D. A. Thomas, Framatome Cogema, 1261 Town Center Drive, Las Vegas, NV 89134

81. P. Thorne, BNFL, Nuclear and Radiological Safety, R101 Rutherford House, Risley Warrington, WA3 6AS

82. M. E. Wangler, U.S. Department of Energy, EH-33.2, Washington, DC 20585-0002 
83. A. Wells, 2846 Peachtree Walk, Duluth, GA 30136

84. W. Weyer, Wissenschaftlich-Technische Ingenieurberatung GMBH, Mozartstrasse 13, 5177 Titz-Rodingen, Federal Republic of Germany

85. B. H. White, IV, U.S. Nuclear Regulatory Commission, Spent Fuel Project Office, MS 13 D13, Washington, DC 20555

86. J. Williams, Office of Civilian Radioactive Waste Management, U.S. Department of Energy, RW-46, Washington, DC 20545

87. M. L. Williams, LSU Nuclear Science Center, Baton Rouge, LA 70803

88. C. J. Withee, U.S. Nuclear Regulatory Commission, Spent Fuel Project Office, MS 13 D13, Washington, DC 20555

89. R. Yang, Electric Power Research Institute, 3412 Hillview Ave., Palo Alto, CA 94304 
